Prepared in cooperation with the City of Lawrence, the City of Topeka, Johnson County WaterOne, the Kansas Water Office, and the Kansas Department of Health and Environment

Fate and Transport of Cyanobacteria and Associated Toxins and Taste-and-Odor Compounds from Upstream Reservoir Releases in the Kansas River, Kansas, September and October 2011

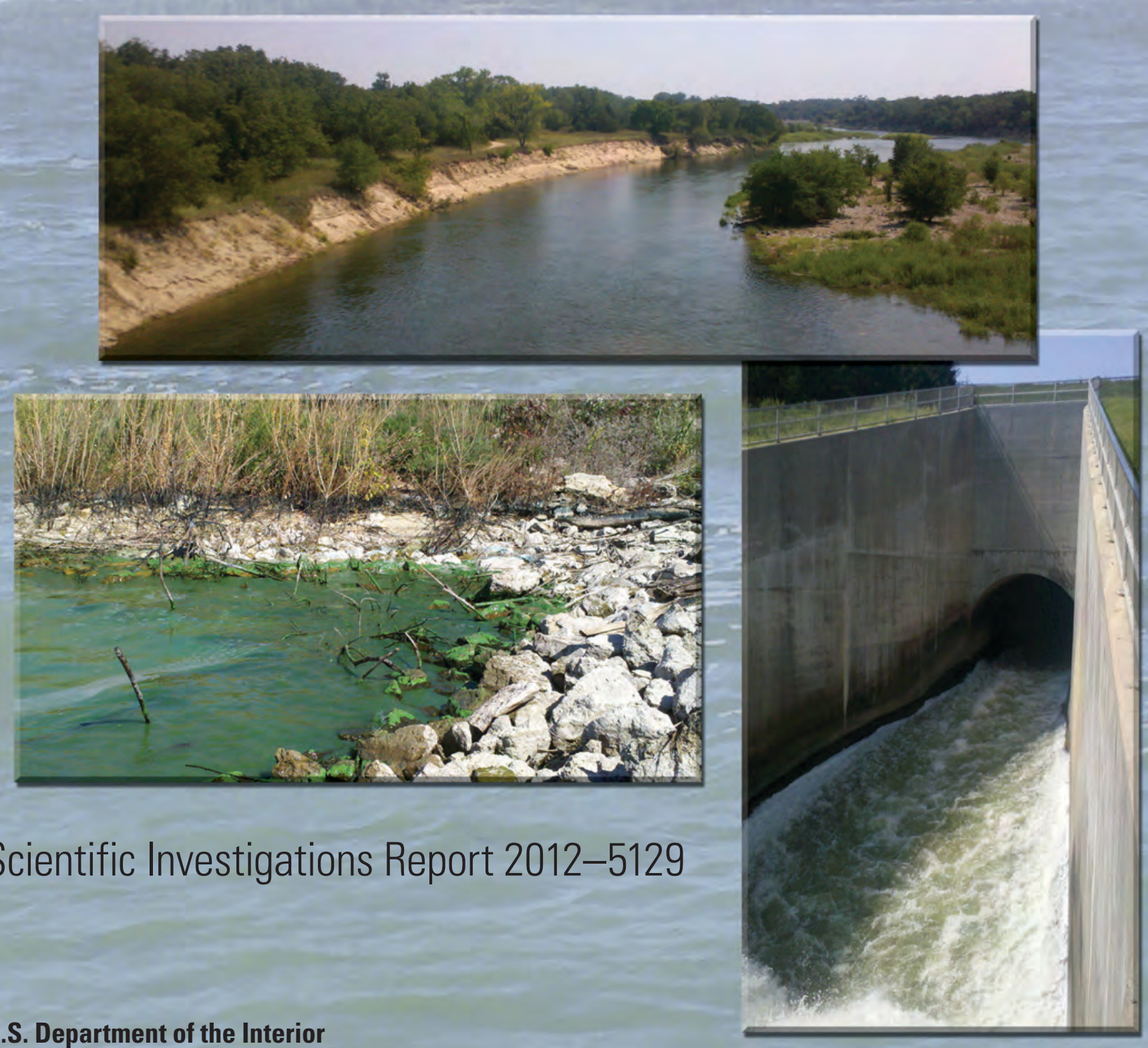

U.S. Geological Survey 
Cover. Upper center: Republican River, downstream from Milford Lake, September 2, 2011.

Lower left: Milford Lake cyanobacterial bloom, September 2, 2011.

Lower right: Milford Lake outflow, September 2, 2011.

Background: Milford Lake, Kansas.

Photographs by U.S. Geological Survey personnel. 


\section{Fate and Transport of Cyanobacteria and Associated Toxins and Taste-and-0dor Compounds from Upstream Reservoir Releases in the Kansas River, Kansas, September and October 2011}

By Jennifer L. Graham, Andrew C. Ziegler, Brian L. Loving, and Keith A. Loftin

Prepared in cooperation with the City of Lawrence, the City of Topeka, Johnson County WaterOne, the Kansas Water Office, and the Kansas Department of Health and Environment

Scientific Investigations Report 2012-5129 


\section{U.S. Department of the Interior \\ KEN SALAZAR, Secretary \\ U.S. Geological Survey \\ Marcia K. McNutt, Director}

\section{U.S. Geological Survey, Reston, Virginia: 2012}

For more information on the USGS - the Federal source for science about the Earth, its natural and living resources, natural hazards, and the environment, visit http://www.usgs.gov or call 1-888-ASK-USGS.

For an overview of USGS information products, including maps, imagery, and publications, visit http://www.usgs.gov/pubprod

To order this and other USGS information products, visit http://store.usgs.gov

Any use of trade, product, or firm names is for descriptive purposes only and does not imply endorsement by the U.S. Government.

Although this report is in the public domain, permission must be secured from the individual copyright owners to reproduce any copyrighted materials contained within this report.

Suggested citation:

Graham, J.L., Ziegler, A.C., Loving, B.L., and Loftin, K.A., 2012, Fate and transport of cyanobacteria and associated toxins and taste-and-odor compounds from upstream reservoir releases in the Kansas River, Kansas, September and October 2011: U.S. Geological Survey Scientific Investigations Report 2012-5129, 65 p. 


\section{Acknowledgments}

The authors thank GreenWater Laboratories and Engineering Performance Solutions, LLC for providing analytical services during a holiday weekend and the frequent and rapid return of analytical results. The authors also thank BSA Environmental Services, Inc. for providing the frequent and rapid return of analytical results. The authors thank Janet Neff, Kansas Department of Health and Environment, for providing information on cyanobacterial blooms in Kansas reservoirs during 2011. Additionally the technical review provided by representatives from the City of Lawrence, City of Topeka, Johnson County WaterOne, Kansas Water Office, Kansas Department of Health and Environment, and U.S. Army Corps of Engineers all contributed to improving the readability, technical accuracy, and content of the report.

The authors thank the U.S. Geological Survey Organic Geochemistry Research Laboratory for providing analytical services during a holiday weekend and the frequent and rapid return of analytical results. Joan Kenny, U.S. Geological Survey, provided information on water use in the lower Kansas River Basin. And last, but not least, the authors thank the U.S. Geological Survey staff that assisted with sample collection, processing, and analysis, including Chelsea Arnold, Patrick Finnegan, Guy Foster, Jackline Gatotho, William Holladay, Eric Looper, Mark Lysaught, Chelsea Paxson, Benjamin Prewitt, Mandy Stone, Spoorthi Tammareddi, and Andrew Toth. 


\section{Contents}

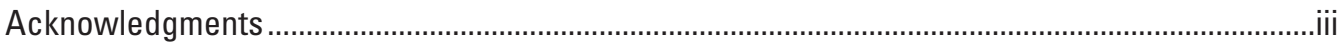

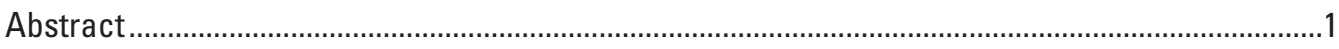

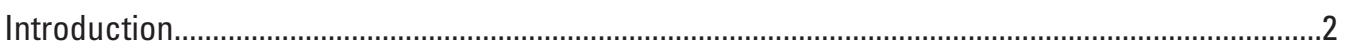

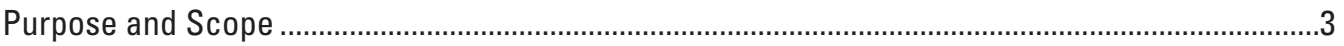

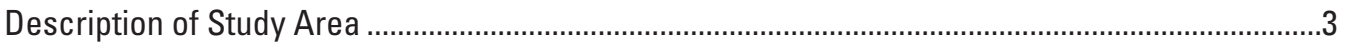

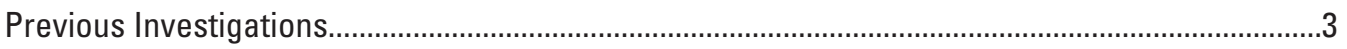

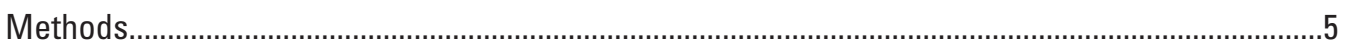

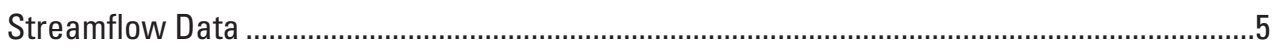

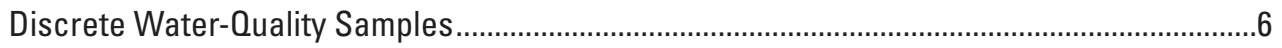

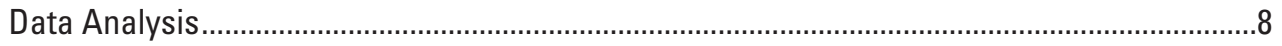

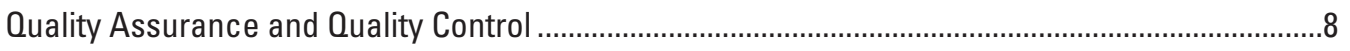

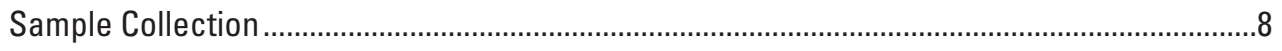

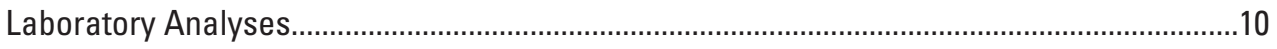

Upstream Reservoir Releases and Streamflow Conditions..........................................................

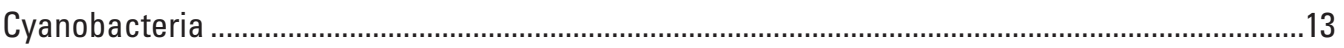

Cyanobacteria in Kansas River Tributaries ..................................................................13

Cyanobacteria in the Kansas River Main Stem .................................................................

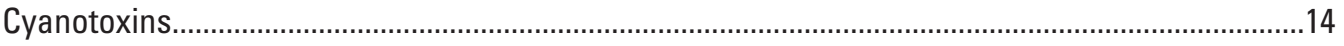

Milford Lake Cyanobacterial Bloom .................................................................................

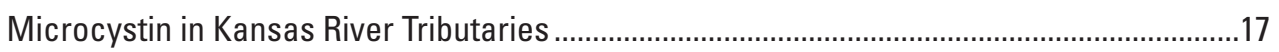

Microcystin in the Kansas River Main Stem …………......................................................18

Microcystin in Treated Drinking Water ............................................................................18

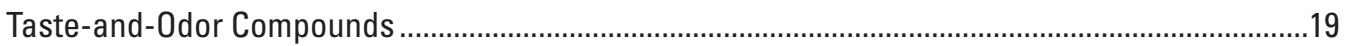

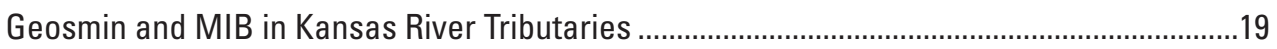

Geosmin and MIB in the Kansas River Main Stem ............................................................19

Co-Occurrence of Cyanotoxins and Taste-and-Odor Compounds ......................................................

Fate and Transport of Cyanobacteria and Associated Toxins and Taste-and-Odor

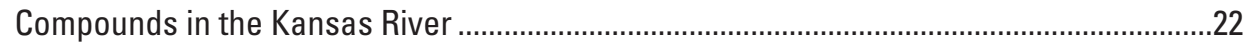

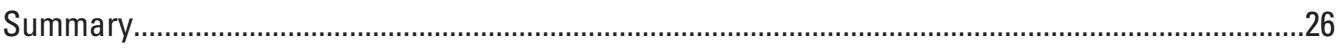

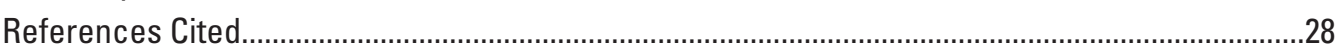

Appendix 1. U.S. Geological Survey streamflow-gaging stations used to describe streamflow conditions in the Kansas River during August through October 2011

Appendix 2. Discrete water-quality sampling results from samples collected from Kansas River tributary and main-stem sites during September and October 2011

Appendix 3. Cyanobacterial community composition in samples collected from Kansas River tributary and main-stem sites during September and October 2011

Appendix 4. Phytoplankton community composition in samples collected from Kansas River tributary and main-stem sites during September and October 2011. 


\section{Figures}

1. Map showing location of reservoirs, U.S. Geological Survey streamflow-gaging stations, and discrete water-quality sampling sites in the lower Kansas River Basin .....4

2. Graph showing reservoir releases, instantaneous streamflow, and timing of discrete-sample collection at Kansas River tributary and main-stem sampling sites during August through October 2011.

3. Graphs showing spatial variability in phytoplankton, cyanobacteria, microcystin, and taste-and-odor compounds in cross-sectional transects .....

4. Graphs showing gaged and expected streamflow at Kansas River main-stem sites on September 8, 2011, September 26, 2011, October 3, 2011, and October 31, 2011

5. Graphs showing cyanobacterial abundance and relative abundance at Kansas River tributary and main-stem sites during September and October 2011

6. Graph showing total microcystin concentrations in Milford Lake upstream (north) from the dam and the Milford Lake outflow during September and October 2011

7. Graph showing total microcystin concentrations in the Republican River, downstream from Milford Lake, and Kansas River main-stem sites during September and October 2011

8. Graph showing total microcystin loads from Milford Lake on sampled days during September and October 2011

9. Graphs showing geosmin and 2-methylisoborneol at Kansas River tributary and main-stem sites during September and October 2011.

10. Graph showing co-occurrence of microcystin and taste-and-odor compounds in Kansas River samples during September and October 2011

11. Graphs showing measured and expected concentrations of cyanobacteria in the Kansas River on September 8, 2011, September 26, 2011, and October 3, 2011, with tributaries labeled.

12. Graphs showing measured and expected concentrations of total microcystin in the Kansas River on September 8, 2011, September 26, 2011, and October 3, 2011, with tributaries labeled

13. Graphs showing measured and expected concentrations of geosmin and 2-methylisoborneol in the Kansas River on September 8, 2011, September 26, 2011, and October 3, 2011, with tributaries labeled...

\section{Tables}

1. Location and description of Kansas River tributary and main-stem sampling sites including drainage area and distance from the main-stem Kansas River or confluence with the Missouri River

2. Comparison of discrete-water-quality sampling results from surface-dip, single integrated-vertical, and equal-width-increment samples collected at the Wamego and Lecompton sites on October 5, 2011

3. Monthly mean streamflows at Kansas River tributary and main-stem sites for August, September, and October during the period of record and 2011

4. Percentage of flow contributed by upstream reservoirs at Kansas River main-stem sites on September 8, 2011, September 26, 2011, October 3, 2011, and October 31, 2011 


\section{Conversion Factors}

\begin{tabular}{lcl}
\multicolumn{1}{c}{ Mnch/Pound to SI } & \multicolumn{1}{c}{ By } & \multicolumn{1}{c}{ To obtain } \\
\hline mile $(\mathrm{mi})$ & Length & kilometer $(\mathrm{km})$ \\
centimeter $(\mathrm{cm})$ & 1.609 & inch $($ in. $)$ \\
micrometer $(\mu \mathrm{m})$ & 0.3937 & centimeter $(\mathrm{cm})$ \\
\hline & 0.0001 & \\
\hline square mile $\left(\mathrm{mi}^{2}\right)$ & Area & square kilometer $\left(\mathrm{km}^{2}\right)$ \\
\hline & 2.590 & cubic meter $\left(\mathrm{m}^{3}\right)$ \\
\hline acre-foot $(\mathrm{acre}-\mathrm{ft})$ & Volume & ounce, fluid $(\mathrm{fl} . \mathrm{oz})$ \\
liter $(\mathrm{L})$ & 1,233 & ounce, fluid $(\mathrm{fl} . \mathrm{oz})$ \\
milliliter $(\mathrm{mL})$ & 33.82 & \\
\hline & 0.0338 & cubic meter per second $\left(\mathrm{m}^{3} / \mathrm{s}\right)$ \\
\hline cubic foot per second $\left(\mathrm{ft}^{3} / \mathrm{s}\right)$ & Flow rate & \\
\hline & 0.02832 & pounds $(\mathrm{lb})$ \\
\hline kilogram $(\mathrm{kg})$ & Mass & gram $(\mathrm{g})$ \\
microgram $(\mu \mathrm{gg})$ & 2.204 & gram $(\mathrm{g})$ \\
nanogram $(\mathrm{ng})$ & 0.000001 &
\end{tabular}

Temperature in degrees Celsius $\left({ }^{\circ} \mathrm{C}\right)$ may be converted to degrees Fahrenheit $\left({ }^{\circ} \mathrm{F}\right)$ as follows:

${ }^{\circ} \mathrm{F}=\left(1.8 x^{\circ} \mathrm{C}\right)+32$

Horizontal coordinate information is referenced to the North American Datum of 1983 (NAD 83).

Specific conductance is given in microsiemens per centimeter at 25 degrees Celsius $(\mu \mathrm{S} / \mathrm{cm}$ at $\left.25^{\circ} \mathrm{C}\right)$.

Concentrations of chemical constituents in water are given either in micrograms per liter $(\mu \mathrm{g} / \mathrm{L})$ or nanograms per liter (ng/L). 


\title{
Fate and Transport of Cyanobacteria and Associated Toxins and Taste-and-Odor Compounds from Upstream Reservoir Releases in the Kansas River, Kansas, September and October, 2011
}

\author{
By Jennifer L. Graham, Andrew C. Ziegler, Brian L. Loving, and Keith A. Loftin
}

\section{Abstract}

Cyanobacteria cause a multitude of water-quality concerns, including the potential to produce toxins and tasteand-odor compounds. Toxins and taste-and-odor compounds may cause substantial economic and public health concerns and are of particular interest in lakes, reservoirs, and rivers that are used for drinking-water supply, recreation, or aquaculture. The Kansas River is a primary source of drinking water for about 800,000 people in northeastern Kansas. Water released from Milford Lake to the Kansas River during a toxic cyanobacterial bloom in late August 2011 prompted concerns about cyanobacteria and associated toxins and taste-and-odor compounds in downstream drinking-water supplies. During September and October 2011 water-quality samples were collected to characterize the transport of cyanobacteria and associated compounds from upstream reservoirs to the Kansas River. This study is one of the first to quantitatively document the transport of cyanobacteria and associated compounds during reservoir releases and improves understanding of the fate and transport of cyanotoxins and taste-and-odor compounds downstream from reservoirs.

Milford Lake was the only reservoir in the study area with an ongoing cyanobacterial bloom during reservoir releases. Concentrations of cyanobacteria and associated toxins and taste-and-odor compounds in Milford Lake (upstream from the dam) were not necessarily indicative of outflow conditions (below the dam). Total microcystin concentrations, one of the most commonly occurring cyanobacterial toxins, in Milford Lake were 650 to 7,500 times higher than the Kansas Department of Health and Environment guidance level for a public health warning (20 micrograms per liter) for most of September 2011. By comparison, total microcystin concentrations in the Milford Lake outflow generally were less than 10 percent of the concentrations in surface accumulations, and never exceeded 20 micrograms per liter.

The Republican River, downstream from Milford Lake, was the only Kansas River tributary with detectable microcystin concentrations throughout the study period, and concentrations exceeded 1 microgram per liter for most of September 2011. Microcystin was detected periodically in other tributaries, but concentrations were low (less than 0.3 micrograms per liter). In contrast, the taste-and-odor compounds geosmin and 2-methylisoborneol (MIB) were detected in all tributaries located immediately downstream from reservoirs and total concentrations generally exceeded the human detection threshold (5 to 10 nanograms per liter) from September through mid-October. Microcystin, geosmin, and MIB were not detected in the Smoky Hill River upstream from the confluence with the Republican River that forms the Kansas River.

Within a week after initial reservoir releases, microcystin, geosmin, and MIB were detected throughout a 173-mile reach of the Kansas River; these compounds remained detectable throughout the reach until mid-October. Losses to groundwater when streamflows in the Kansas River were increasing indicate the potential for reservoir releases to affect groundwater quality as well as surface-water quality. Total microcystin concentrations in the Kansas River generally were highest within about 24 miles of the confluence of the Smoky Hill and Republican Rivers, and decreased downstream; concentrations exceeded 1 microgram per liter in the Kansas River upstream from Topeka during the first 2 weeks of September. Patterns in microcystin occurrence and concentration at Kansas River tributary and main-stem sites indicate that Milford Lake was the source of microcystin in the Kansas River; however, the source of taste-and-odor compounds was not as evident, possibly because multiple tributaries contributed taste-and-odor compounds to the Kansas River.

Microcystin and taste-and-odor compounds co-occurred in 56 percent of samples collected, indicating co-occurrence was common. Despite frequent co-occurrence, the spatial and temporal patterns in microcystin, geosmin, and MIB were unique and did not necessarily match patterns in cyanobacterial abundance. Use of a single compound or cyanobacterial abundance alone cannot necessarily be used as an indicator of the presence or concentration of these compounds. 
Measured concentrations of cyanobacteria and associated compounds were substantially higher than expected concentrations based on simple dilution models at some sites and substantially lower at others, though spatial and temporal patterns were unique for individual compounds. Data were not collected in such a way to determine whether differences between measured and expected concentrations were statistically significant. Results, however, indicate that simple dilution models were not sufficient to describe the downstream transport of cyanobacteria and associated compounds in the Kansas River.

\section{Introduction}

Cyanobacteria (also called blue-green algae) cause a multitude of water-quality concerns, including the potential to produce toxins and taste-and-odor compounds. Toxins and taste-and-odor compounds may cause substantial economic and public health concerns, and are of particular interest in lakes, reservoirs, and rivers that are used for drinking-water supply, recreation, or aquaculture (Graham, 2006). Cyanobacterial toxins (cyanotoxins) have been implicated in human and animal illness and death in at least 36 States in the United States, including Kansas (Graham and others, 2009; van der Merwe and others, 2012). Several countries have set national standards or guidelines for cyanotoxins in drinking and recreational waters (Hudnell, 2008). Cyanotoxins currently (2012) are on the U.S. Environmental Protection Agency (USEPA) drinking-water contaminant candidate list (U.S. Environmental Protection Agency, 2009) and several States include cyanotoxins in their freshwater beach-monitoring programs (Graham and others, 2009). Unlike cyanotoxins, taste-andodor compounds have no known effects on human health, and there are no regulations for these compounds. Aesthetic issues associated with tastes and odors occur at low concentrations (human detection threshold of 5 to 10 nanograms per liter, $\mathrm{ng} / \mathrm{L}$ ) and remedial actions often are implemented as soon as taste or odor is detected in a drinking-water supply (Taylor and others, 2005). Cyanobacterial toxins and taste-and-odor compounds may co-occur, emphasizing the need for increased cyanotoxin surveillance during taste-and-odor occurrences so that treatment can be modified accordingly, and to verify that cyanotoxins are not present in concentrations at or above thresholds of potential health risk (Graham and others, 2010).

The Kansas River and its associated alluvial aquifer are primary sources of drinking water for about 800,000 people in northeastern Kansas (J. Kenny, U.S. Geological Survey, written commun., March 27, 2011). In addition to serving as a drinking-water supply, designated uses of the Kansas River include recreation, aquatic life support, food procurement, groundwater recharge, irrigation, and livestock watering (Kansas Department of Health and Environment, 2011). All of these designated uses potentially may be affected by cyanobacteria and associated toxins and taste-and-odor compounds
(Chorus and Bartram, 1999; Hudnell, 2008). There are no reports of noticeable cyanobacterial blooms developing in the Kansas River (Carney, 2012); however, reservoirs in the lower Kansas River Basin do occasionally develop blooms (J. Neff, Kansas Department of Health and Environment, written communs., January 26, March 19, and June 6, 2012).

Upstream lakes and reservoirs can have substantial effects on phytoplankton abundance and community composition in rivers (Reynolds, 1984; Allan, 1995; Wehr and Sheath, 2003). Downstream transport of cyanobacteria and associated toxins and taste-and-odor compounds from lakes and reservoirs during blooms has been previously documented but is not well quantified (Lehman and others, 2005; Kann and others, 2010; Miller and others, 2010), and transport mechanisms are not well understood. Most current (2012) cyanobacteria transport studies have focused on estuarine areas, where cyanotoxins transported from upstream lakes and reservoirs have caused substantial negative effects. For example, sea otter deaths in Monterey Bay, California were linked to transport of microcystin, one of the most commonly occurring cyanotoxins, from upstream freshwater sources and subsequent accumulation in the bay food web (Miller and others, 2010).

The Kansas Department of Health and Environment (KDHE) used two guidance levels to issue either public health advisories or warnings for cyanobacteria-related harmful algal blooms (HAB) in Kansas lakes and reservoirs during 2011. Cyanobacterial abundances between 20,000 and 100,000 cells per milliliter (cells $/ \mathrm{mL}$ ) or microcystin concentrations less than $20 \mu \mathrm{g} / \mathrm{L}$ were the guidance levels for advisories; cyanobacterial abundances in excess of 100,000 cells $/ \mathrm{mL}$ or microcystin concentrations in excess of $20 \mu \mathrm{g} / \mathrm{L}$ were the guidance levels for warnings (Kansas Department of Health and Environment, 2010). These guidance levels reflect the World Health Organization (WHO) provisional guidelines for moderate and high probability of acute human health effects (Chorus and Bartram, 1999). During 2011, cyanobacterial blooms caused the KDHE to issue public health advisories or warnings for 21 public-use lakes in Kansas, including Perry and Milford Lakes, located in the lower Kansas River Basin (fig. 1). Perry Lake was under advisory or warning for 14 days in July 2011. The cyanobacterial bloom event in Milford Lake lasted from July through October 2011 and the reservoir was under advisory or warning for a total of 98 days (J. Neff, KDHE, written communs., January 26, March 19, and June 6, 2012). After reviewing the 2011 season, the KDHE HAB policy for Kansas recreational waters was revised; most guidance levels for cyanobacterial abundance and microcystin remained unchanged, with the exception of microcystin advisory levels. The current (2012) range of microcystin concentrations for an advisory is between 4 and $20 \mu \mathrm{g} / \mathrm{L}$ (Kansas Department of Health and Environment, 2012).

Because of flooding along the Missouri River, reservoir releases in the lower Kansas River Basin were maintained at low flows during summer 2011 (U.S. Army Corps of Engineers, 2011). When water was released from Milford 
Lake to the Kansas River in late August 2011 to evacuate water that had accumulated in the flood-control pool, the ongoing $\mathrm{HAB}$ warning prompted concerns about cyanobacteria and associated toxins and taste-and-odor compounds in downstream drinking-water supplies. In September 2011, the U.S. Geological Survey (USGS), in cooperation with the City of Lawrence, the City of Topeka, Johnson County WaterOne, the Kansas Water Office, and KDHE, conducted a study to characterize the extent and duration of the transport of cyanobacteria and associated compounds from Milford Lake and other upstream reservoirs to the Kansas River. This study is one of the first to quantitatively document the transport of cyanobacteria and associated compounds during a reservoir release and improves understanding of the fate and transport of cyanotoxins and taste-and-odor compounds downstream from reservoirs.

\section{Purpose and Scope}

The purpose of this report is to characterize the fate and transport of cyanobacteria and associated toxins and tasteand-odor compounds in the Kansas River following upstream reservoir releases. The specific objectives are to describe the extent and duration of the transport of cyanobacteria and associated toxins and taste-and-odor compounds from upstream reservoirs to the Kansas River during September 2 through October 31, 2011, and evaluate the strengths and weaknesses of the sampling plan used during this cyanobacteria-related event so that robust plans to monitor future cyanobacteriarelated events can be developed.

\section{Description of Study Area}

The Kansas River Basin has an area of 60,097 square miles $\left(\mathrm{mi}^{2}\right)$, encompassing the northern one-half of Kansas and parts of Nebraska and Colorado. The Kansas River is formed by the confluence of the Smoky Hill and Republican Rivers, near Junction City, Kansas and flows about 173 miles east into the Missouri River (not shown), near Kansas City, Kansas (fig. 1). The area downstream from the Smoky Hill and Republican Rivers commonly is called the lower Kansas River Basin. Eighteen Federal reservoir projects impound water on all the major tributaries of the Kansas River, controlling streamflow in 85 percent of the drainage area (Perry, 1994). However, the main stem of the Kansas River has only minor control structures, including Bowersock Dam (in Lawrence, Kansas; not shown), a low-head hydroelectric dam, and several diversion weirs for water supply (Kansas Riverkeeper, 2012).

About 77 percent of land use in the study area $\left(5,448 \mathrm{mi}^{2}\right)$ is agricultural (cropland and grassland), with some urban areas (about 9 percent of land use; Fry and others, 2011). Although urban development represents a small part of the total land use, major urban and industrial areas are located along the river at Manhattan, Topeka, Lawrence, and Kansas City, Kansas (fig. 1). All of these cities, in addition to many smaller communities, use water from the Kansas River and its associated alluvial aquifer for municipal water supply.

To characterize the fate and transport of cyanobacteria and associated toxins and taste-and-odor compounds from upstream reservoirs to the Kansas River, 16 sites were sampled (fig. 1, table 1). Streamflow in the study area is regulated by four reservoirs (Milford, Tuttle Creek, Perry, and Clinton; fig. 1). All four are bottom-release reservoirs constructed in the 1960s and 1970s for flood control, but also are used for other purposes including recreation and drinking-water supply (either directly or through releases for downstream use; U.S. Army Corps of Engineers, 2012). Samples were collected on tributary streams (Republican, Big Blue, Delaware, and Wakarusa, respectively; fig. 1) between 2.3 and 5.7 miles downstream from the dams forming the reservoirs. The Smoky Hill River, which is joined by the Republican River to form the Kansas River, also was sampled. Kansas River main-stem sampling sites were located between 14.9 and 170.6 miles upstream from the confluence with the Missouri River (fig. 1, table 1).

\section{Previous Investigations}

The Kansas River has been the subject of numerous studies for a variety of purposes, including water-quality conditions and trends, flooding characteristics, geomorphology, effects of dredging, and effects of urbanization and wastewater discharge (Cross and deNoyelles, 1982; Jordan, 1995; Perry, 1994; Pope, 1994; Jordan and Stamer, 1995; Helgesen, 1996; Pope and Putnam, 1997; Rasmussen and Ziegler, 2003; Rasmussen and Christensen, 2005; Rasmussen and others, 2005). Although these studies were not designed specifically to evaluate the effects of upstream reservoirs on water quality, they have contributed to a general understanding of reservoir effects on Kansas River water-quality conditions. The reservoirs in the lower Kansas River Basin trap nutrients, sediment, and bacteria, and reservoir outflows typically dilute downstream concentrations of these constituents (Rasmussen and Ziegler, 2003; Rasmussen and Christensen, 2005; Rasmussen and others, 2005; Juracek, 2011).

Cyanobacteria commonly occur in Kansas River phytoplankton communities, but typically are not the dominant algal group (Carney, 2012). The effect of upstream reservoirs on phytoplankton community composition in the Kansas River has not been well characterized. Cyanobacterial toxins and taste-and-odor compounds have not been routinely analyzed in the Kansas River and associated tributaries; the occurrence frequency and concentration range of these compounds currently (2012) is unknown. The study described in this report is one of the first to describe cyanobacteria and associated compounds in the Kansas River and document transport from reservoir releases. 

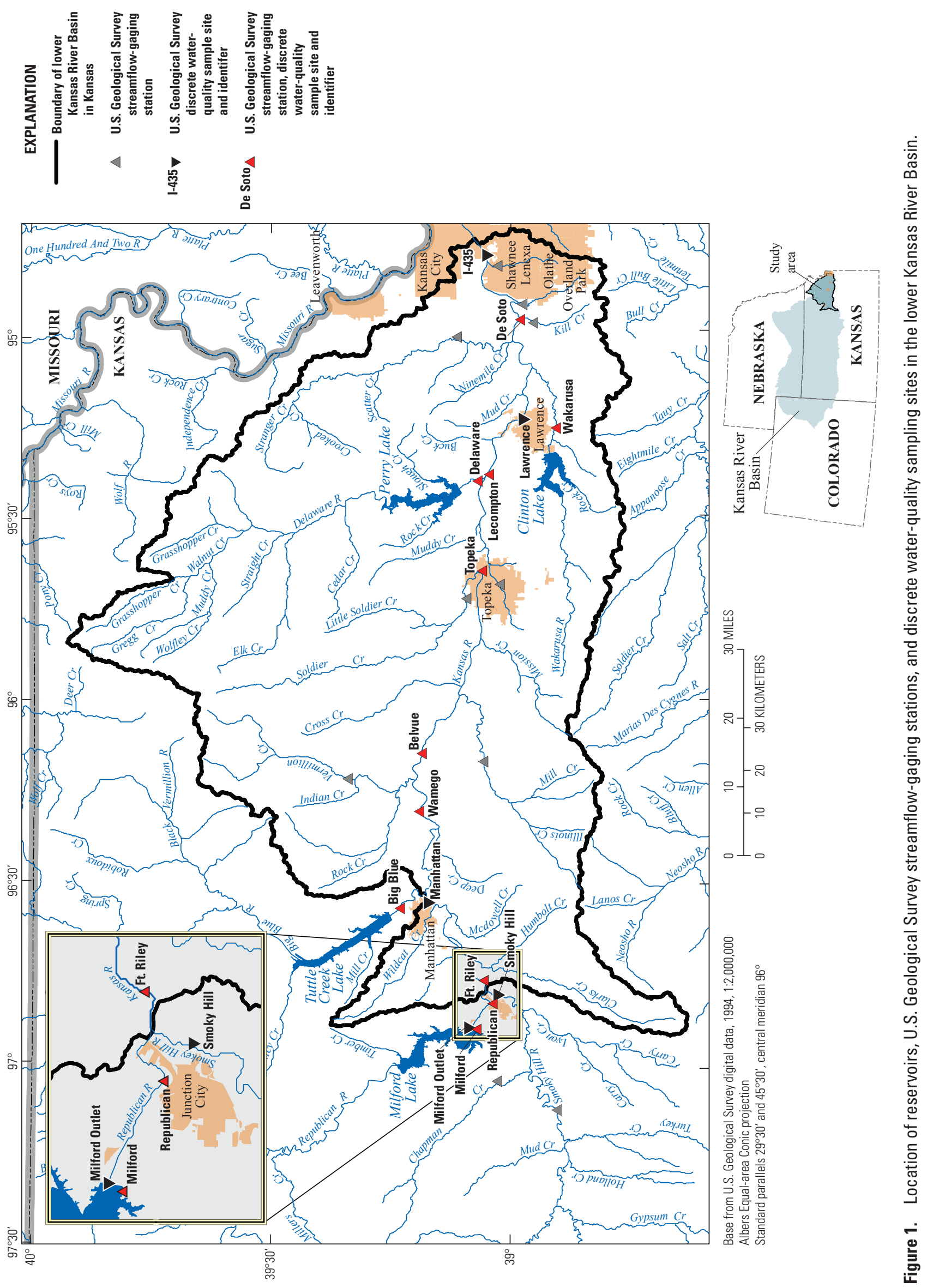
Table 1. Location and description of Kansas River tributary and main-stem sampling sites including drainage area and distance from the main-stem Kansas River or confluence with the Missouri River.

[nr, near; KS, Kansas; R, River; Pl, Plaza]

\begin{tabular}{|c|c|c|c|c|}
\hline $\begin{array}{l}\text { Site identifier } \\
\text { (fig. 1) }\end{array}$ & Site name & $\begin{array}{c}\text { U.S. Geological } \\
\text { Survey identification } \\
\text { number }\end{array}$ & $\begin{array}{l}\text { Drainage area } \\
\text { (square miles) }\end{array}$ & $\begin{array}{l}\text { River miles off Kansas River } \\
\text { main stem or miles upstream } \\
\text { from confluence with } \\
\text { Missouri River }\end{array}$ \\
\hline Milford & Milford Lake nr Junction City, KS & 06857050 & 24,880 & 7.9 \\
\hline Milford Outlet & Milford Lake outlet, KS & 390433096534600 & 24,880 & 7.9 \\
\hline Smoky Hill & Smoky Hill R at Grandview Pl, Junction City, KS & 06879005 & 19,906 & 175.7 \\
\hline Republican & Republican R at Junction City, $\mathrm{KS}^{2}$ & 06857100 & 24,900 & 3.0 \\
\hline Big Blue & Big Blue R nr Manhattan, $\mathrm{KS}^{3}$ & 06887000 & 9,640 & 8.2 \\
\hline Delaware & Delaware R at Perry, $\mathrm{KS}^{4}$ & 06890900 & 1,141 & 1.0 \\
\hline \multicolumn{5}{|c|}{ Kansas River main-stem sampling sites } \\
\hline Manhattan & Kansas R at Manhattan, KS & 06879820 & 45,288 & 149.3 \\
\hline Wamego & Kansas R at Wamego, KS & 06887500 & 55,280 & 128.3 \\
\hline Belvue & Kansas R nr Belvue, KS & 06888350 & 55,870 & 116.4 \\
\hline Topeka & Kansas R at Topeka, KS & 06889000 & 56,720 & 83.8 \\
\hline Lecompton & Kansas R at Lecompton, KS & 06891000 & 58,460 & 64.3 \\
\hline Lawrence & Kansas R at Lawrence, KS & 06891080 & 58,500 & 52.3 \\
\hline De Soto & Kansas R at Desoto, KS & 06892350 & 59,756 & 30.8 \\
\hline $\mathrm{I}-435$ & Kansas R nr I-435 Bridge, KS & 06892518 & 59,994 & 14.9 \\
\hline
\end{tabular}

${ }^{1}$ River miles off Kansas River main stem are given for reservoir and tributary sampling sites; miles upstream from confluence with Missouri River are given for main-stem sampling sites.

${ }^{2}$ Approximately 4.9 miles downstream from the Milford Lake Dam.

${ }^{3}$ Approximately 2.3 miles downstream from the Tuttle Creek Lake Dam.

${ }^{4}$ Approximately 3.6 miles downstream from the Perry Lake Dam.

${ }^{5}$ Approximately 5.7 miles downstream from the Clinton Lake Dam.

\section{Methods}

Discrete water-quality samples were collected during September and October 2011 to characterize the extent and duration of the transport of cyanobacteria and associated toxins and taste-and-odor compounds in the Kansas River. Milford Lake was the only reservoir in the study area with an ongoing cyanobacterial bloom during reservoir releases; therefore, surface accumulations of cyanobacteria several meters upstream (north) of the Milford Lake Dam and the Milford Lake outlet were sampled to generally describe bloom conditions. Tributary sites were sampled to quantify the amount of cyanobacteria and associated compounds contributed by upstream reservoirs and Kansas River main-stem sites were sampled to quantify downstream transport.

\section{Streamflow Data}

Data from 20 USGS streamflow-gaging stations, 6 on the Kansas River and 14 on various tributaries (fig. 1, appendix 1), were used to describe streamflow conditions in the Kansas River during August through October 2011. Streamflow was measured using standard USGS methods (Sauer and Turnipseed, 2010; Turnipseed and Sauer, 2010). Streamflow data were downloaded from the USGS National Water Information System website (http://waterdata.usgs.gov/nwis). 


\section{Discrete Water-Quality Samples}

Discrete water-quality samples were collected from surface accumulations of cyanobacteria several meters upstream from the Milford Lake Dam, the Milford Lake outlet, 5 Kansas River tributary sites, and 9 Kansas River main-stem sites from September 2 through October 31, 2011 (fig. 2, table 1, appendix 2). Samples were collected weekly, but the number of sites sampled and the analyses performed varied depending on cyanotoxin and taste-and-odor results from the previous week. Individual sites were sampled on one to eleven occasions during this study (appendix 2).

Multiparameter YSI 6600EDS water-quality monitors were used to measure specific conductance, $\mathrm{pH}$, water temperature, turbidity (YSI 6136 optical turbidity sensor), dissolved oxygen (YSI optical dissolved oxygen sensor), and fluorescence (YSI 6025 chlorophyll sensor) at each site during sample collection. Monitors were handled, stored, and maintained in accordance with standard USGS procedures (Wagner and others, 2006). These ancillary data are presented in appendix 2.

Most discrete water-quality samples were collected as surface dips from the centroid of flow using a weighted bottle sampler (Lane and others, 2003) and an autoclaved widemouth 1-liter (L) high-density polyethylene (HDPE) bottle following USGS methods (U.S. Geological Survey, variously dated). Two surface-dip samples were collected; one was used to fill a 1-L HDPE bottle and the other to fill a 500-milliliter $(\mathrm{mL})$ HDPE bottle. Sample bottles were triple rinsed with native water before filling. All samples were stored on ice in the dark. Immediately upon return to the laboratory, water from the 1-L bottle was processed for total and dissolved cyanotoxins, total taste-and-odor, and chlorophyll analyses as described in Graham and others (2008) and Hambrook Berkman and Canova (2007). Water in the $500-\mathrm{mL}$ bottle was preserved with a 9:1 Lugol's iodine:acetic acid solution for phytoplankton identification and enumeration. On September 8 and 20, 2011, finished drinking-water samples were collected at three drinking-water treatment facilities that use the Kansas River as a source-water supply and were stored frozen until analysis.

Cyanobacterial toxins and taste-and-odor compounds may occur in particulate (intracellular) and dissolved (extracellular) phases (Graham and others, 2008). During this study, total concentrations were measured in most samples; total concentrations include the particulate and dissolved phases. Analysis of total cyanotoxin concentration is typical because it is indicative of potential maximum exposure (Loftin and others, 2008).

Cyanotoxin samples were analyzed for anatoxin-a and microcystin by GreenWater Laboratories, Palatka, Florida and cylindrospermopsin, microcystin, and saxitoxin by the USGS Organic Geochemistry Research Laboratory (OGRL), Lawrence, Kansas. GreenWater Laboratories analyzed most (about 90 percent) microcystin samples. All samples for total cyanotoxin analyses, with the exception of anatoxin-a, were lysed by three sequential freeze-thaw cycles at the USGS Kansas Water Science Center. After freeze-thaw, samples were filtered using 0.7-micrometer $(\mu \mathrm{m})$ syringe filters (Loftin and others, 2008). Abraxis $^{\circledR}$ enzyme-linked immunosorbent assays (ELISA) were used to measure microcystin (detection limit 0.1 micrograms per liter, $\mu \mathrm{g} / \mathrm{L}$; congener independent), cylindrospermopsin (detection limit $0.4 \mu \mathrm{g} / \mathrm{L}$ ), and saxitoxin (detection limit $0.02 \mu \mathrm{g} / \mathrm{L}$ ). Many of the cyanotoxins have multiple variants (congeners) and ELISA is not specific to individual variants; therefore, reported concentrations potentially include multiple variants, degradates, and precursors. Cyanotoxin data are presented in appendix 2.

Anatoxin-a samples were lysed at GreenWater Laboratories by sonication for 8 minutes using an ultrasonic homogenizer (Rapala and others, 2002; Spoof and others, 2003). Following lysis, samples were extracted using solid phase extraction (SPE). Anatoxin-a was analyzed on a ThermoFinnigan LCQ Advantage MS $^{\circledR}$ ion-trap liquid chromatography-mass spectrometer (LC/MS/MS) using the combined methodology of Friday and Carmichael (2001) and Dell'Aversano and others (2004). The $[\mathrm{M}+\mathrm{H}]^{+}$ions for anatoxin-a (mass-to-charge ratio $(\mathrm{m} / \mathrm{z}) \mathrm{166}$ ) were fragmented and the major product ions $(\mathrm{m} / \mathrm{z} 149,131,107$, and 91) provided specificity and sensitivity. Standard addition was utilized for the quantitation of all samples and also provides additional confirmation.

Taste-and-odor samples were analyzed for geosmin and 2-methylisoborneol (MIB) by Engineering Performance Solutions, LLC, Gainesville, Florida. Geosmin and MIB were analyzed by solid-phase microextraction gas chromatography/ mass spectrometry (SPME GC/MS; method detection limit $2 \mathrm{ng} / \mathrm{L}$ ) following USGS methods (Zimmerman and others, 2002). Taste-and-odor data are presented in appendix 2 .

Chlorophyll was analyzed at the USGS Kansas Water Science Center. Total chlorophyll (uncorrected for degradation products) was extracted in heated ethanol (Sartory and Grobbelar, 1986) and analyzed fluorometrically using USEPA Method 445.0 (Knowlton, 1984; Arar and Collins, 1997). Chlorophyll data are presented in appendix 2.

Phytoplankton samples were analyzed for taxonomic identification and enumeration by BSA Environmental Services, Inc., Beachwood, Ohio. Phytoplankton were enumerated to the lowest possible taxonomic level using membrane-filtered slides (McNabb, 1960). A minimum of 400 natural units (colonies, filaments, and unicells) were counted from each sample; in accordance with Lund and others (1958), counting 400 natural units provides accuracy within 90 percent confidence limits. In addition, an entire strip of the filter was counted at high magnification (usually $630 \mathrm{X}$ ) along with one-half of the filter at a lower magnification (usually $400 \mathrm{X}$ ) to ensure complete species reporting. Taxonomic data are presented in appendixes 3 and 4. 


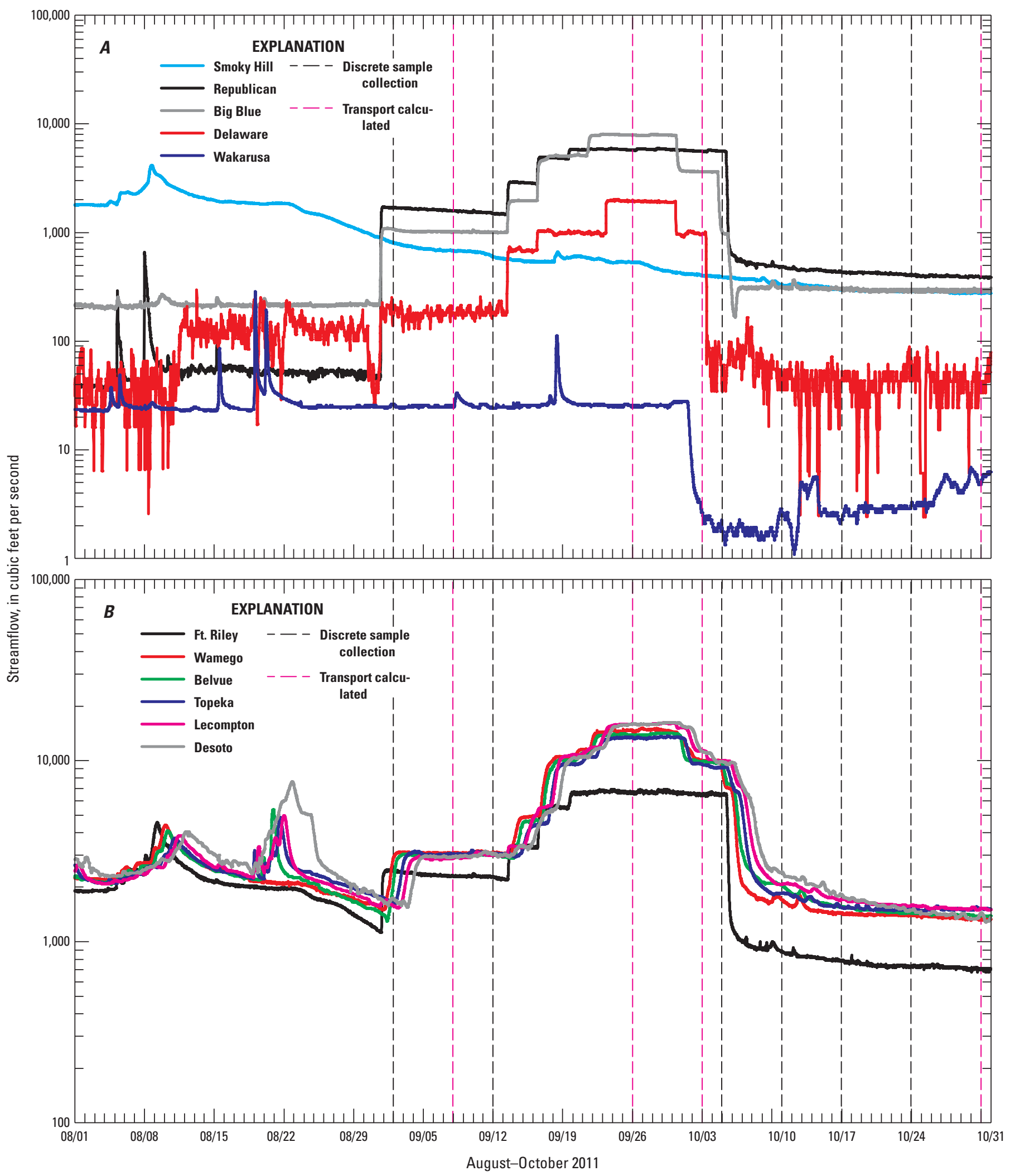

Figure 2. Reservoir releases, instantaneous streamflow, and timing of discrete-sample collection at $(A)$ Kansas River tributary and $(B)$ main-stem sampling sites during August through October 2011. Dashed lines indicate dates when discrete water-quality samples were collected. Dashed lines in red indicate dates when flow contributions by reservoir releases and simple dilution models (transport) were calculated. Smoky Hill River streamflow data are from the streamflow-gaging station at Enterprise (U.S. Geological Survey identification number 06877600) because there is not a streamflow-gaging station at Junction City. 


\section{Data Analysis}

Stable streamflow conditions in the Kansas River were rare during the study period, and water gains and losses occurred between sites. For example, streamflow frequently was higher at the Wamego site than the Topeka site, which is about 44.5 miles downstream from Wamego (fig. 2B). Dynamic streamflow conditions complicate calculations of the percentage of flow contributed by reservoir outflows and simple dilution models. The percentage of flow contributed by reservoir outflows and simple dilution models were calculated for four dates (September 8, 2011; September 26, 2011; October 3, 2011; and October 31, 2011) when streamflow conditions were stable for at least 48 hours before sample collection (fig. $2 B$ ). Streamflows during these four dates generally were representative of the range of streamflow conditions in the Kansas River during and after reservoir releases.

Gains and losses in streamflow at each gaged Kansas River main-stem site (figs. 1 and $2 B$ ) were quantified for the four dates when streamflow conditions were stable by comparing gaged daily mean streamflow to expected daily mean streamflow based on inflows between two gaged sites. Inflows between two gaged sites were calculated as the sum of the daily mean streamflow from gaged and ungaged tributaries in the intervening drainage area (IDA) between sites. Ungaged streamflow was estimated by multiplying the gaged streamflow in the unregulated IDA by the ratio of ungaged to gaged IDA (Hirsch, 1979). Net gains and losses in streamflow were assumed to be from groundwater; however, water withdrawals and discharges also may be important at some sites.

The percentage of flow contributed by reservoir outflow at each gaged Kansas River main-stem site was calculated as:

$$
P=\left[\left(Q_{o}-\left(Q_{o} * X\right) / Q_{G}\right)\right] \times 100
$$

where

$$
\begin{aligned}
& P \quad \text { is the percentage of flow contributed by } \\
& \text { outflow from a given reservoir, } \\
& Q_{O} \quad \text { is gaged streamflow at the reservoir outflow, } \\
& Q_{G} \quad \text { is gaged streamflow at the main-stem site, and } \\
& X \text { is the cumulative proportion of streamflow } \\
& \text { lost between all upstream main-stem sites. }
\end{aligned}
$$

This approach assumes that Kansas River water from all sources is well mixed and lost equally and that losses to groundwater are permanent.

Based on the simple dilution model described in Hem (1985), cyanobacteria, microcystin, and taste-and-odor concentrations in reservoir outflows were multiplied by $P$ to calculate expected concentrations at Kansas River main-stem sites. Expected concentrations from all upstream reservoir outflows were summed for sites affected by multiple reservoirs. This approach assumes a constant load is entering from upstream reservoir outflows and that dilution is the only factor influencing changes in concentration at downstream sites. Three ungaged Kansas River main-stem sites were sampled
(Manhattan, Lawrence, and I-435; fig. 1); given the stable streamflow conditions and low streamflows at gaged tributaries (cumulative streamflows less than or equal to 12 cubic feet per second, $\mathrm{ft}^{3} / \mathrm{s}$ ) when $P$ was calculated, the percentage of flow contributed by reservoir outflows at these sites was assumed to be the same as the closest gaged site upstream (Ft. Riley, Lecompton, and De Soto; fig. 1).

\section{Quality Assurance and Quality Control}

Quality-assurance and quality-control samples were collected to evaluate variability in sample collection and processing techniques and among laboratory variability in analytical techniques. Relative percentage difference (RPD) was used to evaluate differences in analyte concentrations detected in replicate pairs of samples. The RPD was calculated using the following equation:

$$
R P D=\left[|A-B| /\left(\frac{A+B}{2}\right)\right] \times 100
$$

where $A$ and $B$ are concentrations in each replicate pair.

\section{Sample Collection}

Understanding the effect of sample location and method is essential to the design of effective monitoring strategies and studies to quantify fate and transport of cyanobacteria and associated compounds. Collection of surface-dip samples is a rapid approach suitable for collecting numerous samples to evaluate occurrence; however, surface-dip samples may not be representative of overall stream conditions if water is not well mixed or suspended materials, such as algae, are not uniformly distributed (U.S. Geological Survey, variously dated). Discrete surface-dip and single integrated-vertical samples from crosschannel transects and equal-width-increment (EWI) samples were collected following USGS protocols (U.S. Geological Survey, variously dated) at two sites (Wamego and Lecompton; fig. 1, table 1) to describe variability in cyanobacteria, cyanotoxins, and taste-and-odor compounds, and sampling techniques. Cross-channel transects were divided into 10 equal-width increments. Single integrated-vertical samples were collected at the center of each increment by lowering and raising the sampler through the water column. For the EWI samples, integrated-vertical samples were collected at the center of each increment and combined into one sample. The EWI method results in a composite sample that represents the discharge-weighted concentration of the cross-channel transect being sampled (U.S. Geological Survey, 2006).

Overall, phytoplankton abundance varied by a factor of about two along cross-channel transects. In contrast, cyanobacterial abundance varied by as much as a factor of about 5,000 (fig. 3), suggesting the transport of cyanobacteria differed from other algal groups. Many cyanobacteria have the 

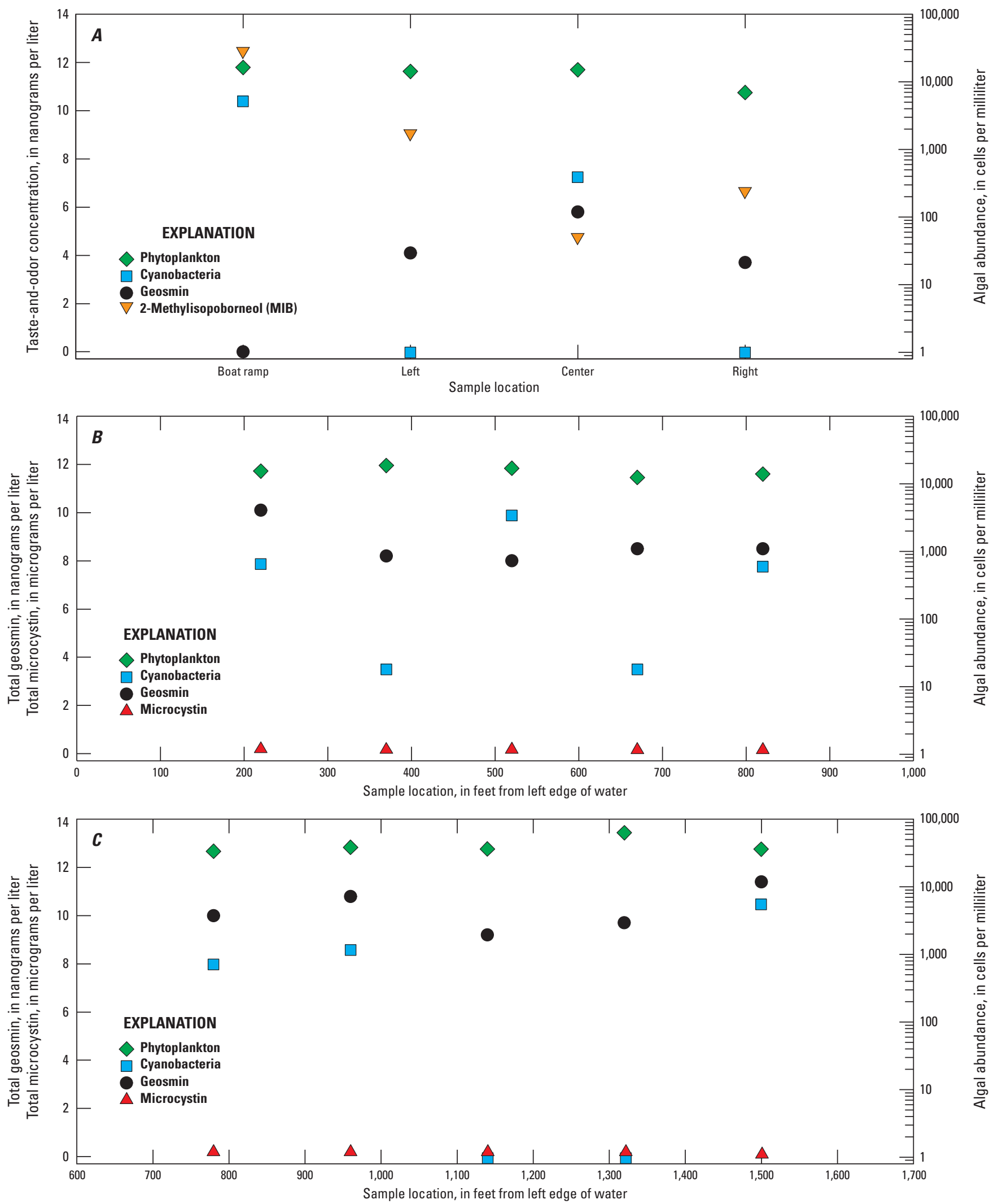

Figure 3. Spatial variability in phytoplankton, cyanobacteria, microcystin, and taste-and-odor compounds in cross-sectional transects. (A) Lecompton, September 20, 2011. Surface-grab samples were collected; microcystin was not analyzed. (B) Wamego, 0ctober 5, 2011. Single integrated-vertical samples were collected; 2-methylisoborneol (MIB) was not detected. (C) Lecompton, 0ctober 5, 2011. Single integrated-vertical samples were collected; 2-methylisoborneol (MIB) was not detected. 
ability to regulate buoyancy and control their position in the water column (Reynolds, 1987), which may result in differential transport of these organisms. Microcystin, geosmin, and MIB concentrations were less variable than cyanobacterial abundance; concentrations of these compounds varied by as much as a factor of about two along cross-channel transects. Cross-sectional patterns in the concentration of each compound were unique, and did not necessarily match patterns in cyanobacterial abundance (fig. 3). Cyanobacterial toxins and taste-and-odor compounds may occur in particulate (intracellular) or dissolved (extracellular) phases or both, which may lead to spatial uncoupling of cyanobacteria and their associated compounds (Graham and others, 2008).

Concentrations of cyanobacteria and associated compounds were compared in surface-dip and single integratedvertical samples collected at the centroid of flow, and EWI samples. The RPD's between samples ranged from 0 to 200 percent and varied depending on sample type, constituent, and site (table 2). In general, RPDs were higher for phytoplankton and cyanobacterial abundance (range: 6 to 200 percent, median: 138 percent) than for other constituents (range: 0 to 49 percent, median: 7 percent). The RPDs between single integrated-vertical and EWI samples were generally lower (range: 0 to 198 percent, median: 8 percent) than the RPDs between single integrated-vertical and surface dip samples (range: 0 to 200 percent, median: 24 percent) or surface-dip and EWI samples (range: 0 to 200 percent, median: 20 percent). These data indicate that single integrated-vertical samples at the centroid of flow may be a useful compromise between surface-dip and EWI sampling methods when a rapid approach is needed.

\section{Laboratory Analyses}

A comparison of microcystin analysis by GreenWater Laboratories and the OGRL was done on 23 laboratory splitreplicate samples. Microcystin was detected in 52 percent of samples analyzed by GreenWater Laboratories and 61 percent of samples analyzed by the OGRL. Samples with detections by the OGRL but not GreenWater Laboratories occurred when concentrations were near the method reporting limit $(0.1 \mu \mathrm{g} / \mathrm{L})$. The RPDs in samples with detections by both laboratories ranged from 2 to 88 percent (median: 24 percent; number of pairs $=15$ ), and the absolute difference in microcystin concentrations between replicate pairs was $3 \mu \mathrm{g} / \mathrm{L}$ or less.

\section{Upstream Reservoir Releases and Streamflow Conditions}

Reservoirs in the Kansas River Basin control streamflow in 85 percent of the drainage area and flood-control operations reduce flooding along the Kansas and lower Missouri Rivers (Perry, 1994). Flood-control reservoirs temporarily store flood waters to reduce downstream flood peaks and streamflow conditions downstream from a reservoir need to be considered before substantial releases are made. Because of flooding along the Missouri River, reservoir releases in the lower Kansas River Basin were maintained at low flows from June through August, 2011 (U.S. Army Corps of Engineers, 2011). From August 31 through October 5, 2011, releases from Milford (Republican River), Tuttle Creek (Big Blue River), and Perry (Delaware River) Lakes were increased (fig. $2 A$ ) to evacuate water that had accumulated in the flood-control pool; releases from Clinton Lake (Wakarusa River) were decreased from about $25 \mathrm{ft}^{3} / \mathrm{s}$ to $2 \mathrm{ft}^{3} / \mathrm{s}$ during the same period. Releases varied by reservoir, but, in general, maximum releases (about 6,$000 ; 8,000$; and $2,000 \mathrm{ft}^{3} / \mathrm{s}$, respectively) were reached around September 20, 2011, and maintained for 1 to 2 weeks (fig. 2A). Based on daily mean streamflow downstream from the reservoirs (sites on the Republican, Big Blue, and Delaware Rivers, respectively), about 270,000 acre-feet (acre-ft) of water was released from Milford Lake, 260,000 acre-ft was released from Tuttle Creek Lake, and 56,000 acre-ft was released from Perry Lake between August 31 and October 5, 2011.

Substantial runoff did not occur during the study period; therefore, reservoir releases were the primary cause of increased streamflow at Kansas River main-stem sites during September and October 2011. Streamflow at most Kansas River main-stem sites increased by about a factor of 10 during peak reservoir releases (fig. $2 B$ ). Visual inspection of hydrographs indicate that, during this event, when streamflow on the Kansas River exceeded about 3,000 ft $3 / \mathrm{s}$, water released from Milford Lake took about 28 hours to reach Topeka, 36 hours to reach Lecompton, and 51 hours to reach De Soto.

In August 2011, before reservoir releases, monthly mean streamflow at most sites was between 1.3 and 15 times lower than the monthly mean for the period of record, likely because reservoir outflows were being maintained at a low level. The only tributary site with a higher monthly mean streamflow in August 2011 was the Smoky Hill River at Enterprise, which is not affected by the lower Kansas River Basin reservoirs (table 3). During peak reservoir releases (September 2011), monthly mean streamflows at the Republican, Big Blue, and Delaware River sites were between 1.3 and 4.7 times higher than the monthly mean for the period of record. Monthly mean streamflow in October 2011 was between 1.4 and 52 times lower than the monthly mean for the period of record at all sites, except the Republican River downstream from Milford Lake. Republican River monthly mean streamflow in October 2011 was about 1.6 times higher than the monthly mean for the period of record, likely because water continued to be released from Milford Lake at about $400 \mathrm{ft}^{3} / \mathrm{s}$ throughout October (fig. $2 A$ ).

The percentage of streamflow contributed by reservoir outflows was calculated on four dates when streamflow conditions were stable for 48 hours before sample collection (September 8, 2011, September 26, 2011, October 3, 2011, and October 31, 2011). During peak reservoir releases 
Table 2. Comparison of discrete-water-quality sampling results from surface-dip, single integrated-vertical, and equal-widthincrement samples collected at the Wamego and Lecompton sites on October 5, 2011.

[EWI, equal width increment; RPD, relative percentage difference; cells/mL, cells per milliliter; $\mu \mathrm{g} / \mathrm{L}$, micrograms per liter; ng/L, nanograms per liter; MIB, 2-methylisoborneol; --, RPD could not be calculated; <, less than]

\begin{tabular}{|c|c|c|c|c|c|c|}
\hline & $\begin{array}{l}\text { Surface-dip } \\
\text { sample }\end{array}$ & $\begin{array}{c}\text { Single } \\
\text { integrated- } \\
\text { vertical sample }\end{array}$ & $\begin{array}{c}\text { EWI } \\
\text { sample }\end{array}$ & $\begin{array}{l}\text { RPD surface-dip } \\
\text { and single-vertical } \\
\text { samples }\end{array}$ & $\begin{array}{l}\text { RPD surface-dip } \\
\text { and EWI samples }\end{array}$ & $\begin{array}{l}\text { RPD single-vertical } \\
\text { and EWI samples }\end{array}$ \\
\hline \multicolumn{7}{|c|}{ Wamego } \\
\hline $\begin{array}{l}\text { Phytoplankton abundance } \\
\text { (cells } / \mathrm{mL})\end{array}$ & 3,100 & 17,000 & 15,000 & 138 & 131 & 13 \\
\hline $\begin{array}{l}\text { Cyanobacterial abundance } \\
(\text { cells } / \mathrm{mL})\end{array}$ & 0 & 3,400 & 14 & 200 & 200 & 198 \\
\hline Chlorophyll ( $\mu \mathrm{g} / \mathrm{L})$ & 12 & 12 & 13 & 0 & 8 & 8 \\
\hline Microcystin $(\mu \mathrm{g} / \mathrm{L})$ & 0.17 & 0.17 & 0.17 & 0 & 0 & 0 \\
\hline Geosmin (ng/L) & 8.4 & 8.0 & 7.4 & 5 & 13 & 8 \\
\hline $\operatorname{MIB}(n g / L)$ & $<2.0$ & $<2.0$ & $<2.0$ & -- & -- & -- \\
\hline \multicolumn{7}{|c|}{ Lecompton } \\
\hline Chlorophyll $(\mu \mathrm{g} / \mathrm{L})$ & 32 & 31 & 33 & 3 & 3 & 6 \\
\hline Microcystin $(\mu \mathrm{g} / \mathrm{L})$ & 0.22 & 0.17 & 0.22 & 26 & 0 & 26 \\
\hline Geosmin (ng/L) & 14 & 9.2 & 8.5 & 41 & 49 & 8 \\
\hline MIB (ng/L) & $<2.0$ & $<2.0$ & $<2.0$ & -- & -- & -- \\
\hline
\end{tabular}

Table 3. Monthly mean streamflows at Kansas River tributary and main-stem sites for August, September, and October during the period of record and 2011.

[Smoky Hill River streamflow data are from the streamflow-gaging site at Enterprise (USGS identification number 06877600) because there is not a streamflowgaging station at Junction City; $\mathrm{ft}^{3} / \mathrm{s}$, cubic feet per second]

\begin{tabular}{|c|c|c|c|c|c|c|}
\hline \multirow{2}{*}{ Site identifier } & \multicolumn{3}{|c|}{$\begin{array}{l}\text { Monthly mean streamflow }\left(\mathrm{ft}^{3} / \mathrm{s}\right) \text { for the period of } \\
\text { record post upstream impoundment }{ }^{1}\end{array}$} & \multicolumn{3}{|c|}{ Monthly mean streamflow (ft³/s) for 2011} \\
\hline & August & September & October & August & September & October \\
\hline \multicolumn{7}{|c|}{ Kansas River tributary sampling sites } \\
\hline Smoky Hill at Enterprise & 1,550 & 1,580 & 1,230 & 1,900 & 601 & 324 \\
\hline Republican & 1,050 & 709 & 732 & 70.7 & 3,660 & 1,200 \\
\hline Wakarusa & 155 & 128 & 192 & 28.3 & 26.6 & 3.72 \\
\hline \multicolumn{7}{|c|}{ Kansas River main-stem sampling sites } \\
\hline Ft. Riley & 2,760 & 2,160 & 2,260 & 2,100 & 4,400 & 1,660 \\
\hline Wamego & 5,700 & 4,250 & 4,180 & 2,350 & 7,900 & 2,920 \\
\hline De Soto & 8,620 & 5,880 & 5,950 & 3,070 & 7,440 & 3,820 \\
\hline
\end{tabular}

${ }^{1}$ Period of record post most recent upstream impoundment for: Republican, Ft. Riley, Wamego, and Topeka, August 1967-October 2011; Big Blue, May 1963-October 2011; Delaware, July 1970-October 2011; Wakarusa, May 1980-October 2011; Smoky Hill at Enterprise, October 1934-October 2011; Belvue, October 1982-October 2011; Lecompton, July 1970-October 2011; Desoto, May 1980-October 2011. 
(September 26 and October 3, 2011), upstream reservoirs contributed between 81 and 93 percent to total streamflow at Kansas River main-stem sites (table 4). Following reservoir releases (October 31, 2011), upstream reservoirs contributed between 44 and 55 percent to total streamflow. The relative contribution of water from Milford Lake was highest at Ft. Riley (55 to 87 percent of total streamflow) and lowest at De Soto (23 to 47 percent); however, differences among sites downstream from Ft. Riley (fig. 1) were small (less than 10 percent; table 4). Tuttle Creek Lake contributed between 18 and 53 percent to total streamflow at downstream sites in the Kansas River (fig. 1), and differences among sites were small (less than 10 percent). Contributions from Perry Lake (3 to 12 percent of total streamflow) and Clinton Lake (less than 1 percent) to total streamflow at downstream sites (Lecompton and De Soto) were small during September and October 2011 (table 4).
Bank storage is water that may be held in a river bank and contribute to streamflow; however, under high-flow conditions water may percolate from the river into the banks (Todd, 1964). On September 8, 2011, about 9 days after initial reservoir releases (fig. 2), gaged streamflows at Kansas River main-stem sites downstream from Ft. Riley were between 8 and 20 percent less than estimated streamflows based on upstream inflows, with the highest losses occurring at Lecompton (river mile 64.3; fig. 1, table 1) and De Soto (river mile 30.8; fig. 1, table 1) (fig. 4A). The opposite pattern was observed on October 31, 2011, about 20 days after streamflow in the Kansas River had returned to conditions similar to those before reservoir releases; gaged streamflows at Kansas River main-stem sites downstream from Ft. Riley (river mile 170.6; fig. 1, table 1) were 24 to 37 percent higher than estimated streamflows, with the highest gains occurring at Topeka (river mile 83.8; fig. 1, table 1) and Lecompton (river mile 64.3;

Table 4. Percentage of flow contributed by upstream reservoirs at Kansas River main-stem sites on September 8, 2011, September 26, 2011, October 3, 2011, and October 31, 2011.

\begin{tabular}{|c|c|c|c|c|}
\hline \multirow{2}{*}{ Reservoir } & \multicolumn{4}{|c|}{ Percentage of flow contributed by upstream reservoirs } \\
\hline & September 8 & September 26 & October 3 & October 31 \\
\hline \multicolumn{5}{|c|}{ Ft. Riley } \\
\hline Milford & 68 & 87 & 86 & 55 \\
\hline \multicolumn{5}{|c|}{ Wamego } \\
\hline Milford & 47 & 40 & 55 & 29 \\
\hline Tuttle Creek & 32 & 53 & 36 & 22 \\
\hline Total & 79 & 93 & 91 & 51 \\
\hline \multicolumn{5}{|c|}{ Belvue } \\
\hline Milford & 47 & 40 & 55 & 28 \\
\hline Tuttle Creek & 31 & 53 & 36 & 21 \\
\hline Total & 78 & 93 & 91 & 49 \\
\hline \multicolumn{5}{|c|}{ Topeka } \\
\hline Milford & 46 & 40 & 55 & 25 \\
\hline Tuttle Creek & 31 & 53 & 36 & 19 \\
\hline Total & 77 & 93 & 91 & 44 \\
\hline \multicolumn{5}{|c|}{ Lecompton } \\
\hline Milford & 43 & 33 & 49 & 24 \\
\hline Tuttle Creek & 29 & 45 & 31 & 18 \\
\hline Perry & 6 & 12 & 4 & 3 \\
\hline Total & 78 & 90 & 84 & 45 \\
\hline \multicolumn{5}{|c|}{ De Soto } \\
\hline Milford & 42 & 33 & 47 & 23 \\
\hline Tuttle Creek & 28 & 45 & 30 & 18 \\
\hline Perry & 6 & 12 & 4 & 3 \\
\hline Clinton & 1 & 0.2 & 0.02 & 0.4 \\
\hline Total & 77 & 90 & 81 & 44 \\
\hline
\end{tabular}


fig. 1, table 1) (fig. 4D). On September 26 and October 3, 2011, when reservoir releases and streamflows in the Kansas River were at their maximum, the difference between gaged and estimated streamflows was less than 10 percent at all sites (fig. $4 B$ and $C$ ). The observed losses to, and gains from, groundwater throughout the course of reservoir releases to the Kansas River are characteristic of bank storage (Todd, 1964), and demonstrate the connectivity between surface water and groundwater during this event. Losses to groundwater when streamflows in the Kansas River main stem were increasing and bank storage occurred indicate the potential for reservoir releases to affect groundwater quality, as well as surface-water quality in the lower Kansas River Basin.

\section{Cyanobacteria}

Reservoirs can have a substantial effect on phytoplankton community composition in rivers; however, rapid attrition of reservoir communities once they enter riverine systems is common. The diatoms (Bacillariophyta) and cyanobacteria (Cyanophyta) tend to persist farther downstream than other algal groups, likely because of differential trapping and settling. In general, diatoms tend to dominate phytoplankton communities in rivers, but cyanobacteria also may be present (Allan, 1995; Wehr and Sheath, 2003). Cyanobacteria may form the dense blooms more characteristic of lakes and reservoirs in rivers, particularly during hot weather conditions with little streamflow (Baker and Baker, 1981; Krogmann and others, 1986; Paerl and Bowles, 1987; Bowling and Baker, 1996).

Nine cyanobacterial genera were present at Kansas River tributary and main-stem sites during September and October 2011 and included Anabaena, Anabaenopsis, Aphanizomenon, Aphanocapsa, Chroococcus, Cylindrospermopsis, Microcystis, Phormidium, and Pseudanabaena (appendix 3). All but one of the cyanobacterial genera present (Chroococcus) are known producers of cyanotoxins and taste-and-odor compounds (Graham and others, 2008). In general, all genera were present at tributary and main-stem sites. Most genera were rare, occurring in less than 20 percent of samples (number of samples $(n)=70)$. Anabaena and Microcystis, present in 39 and 44 percent of samples, respectively, were the most commonly occurring genera. Anabaena and Microcystis are known microcystin producers, and Anabaena also may produce anatoxin and geosmin (Graham and others, 2008).
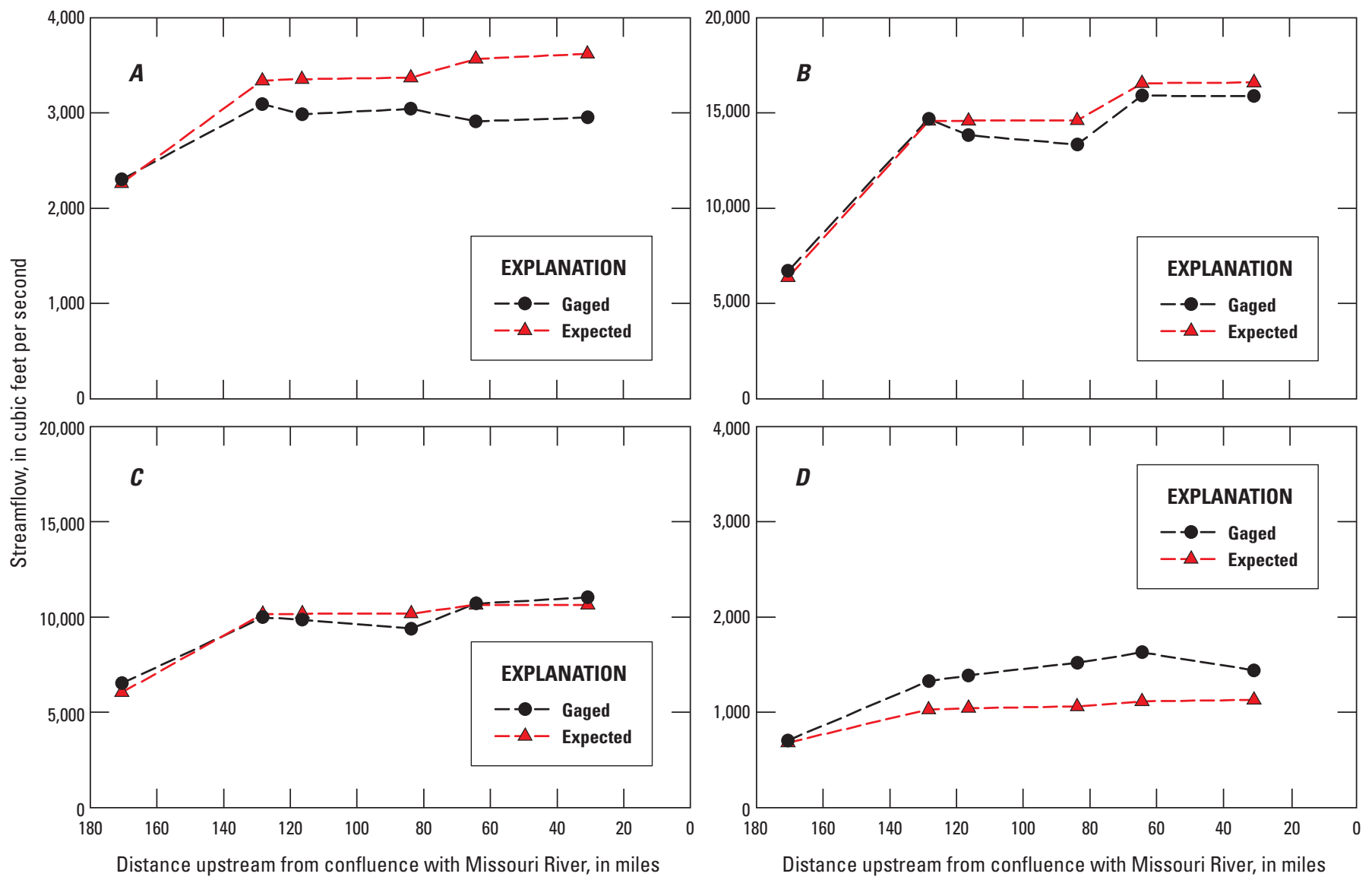

Figure 4. Gaged and expected streamflow at Kansas River main-stem sites on (A) September 8, 2011, (B) September 26, 2011, (C) October 3, 2011, and (D) October 31, 2011. 


\section{Cyanobacteria in Kansas River Tributaries}

Cyanobacteria occasionally were present at all Kansas River tributary sites, but occurred most frequently in the Republican River downstream from Milford Lake and in the Delaware River downstream from Perry Lake (fig. 5A). The Republican River was the only tributary where cyanobacteria dominated (greater than 50 percent of total abundance) the phytoplankton community (fig. $5 B$ ). Cyanobacteria at other tributary sites downstream from reservoirs typically contributed less than 25 percent to total phytoplankton abundance and cyanobacteria in the Smoky Hill River contributed less than 1 percent to total phytoplankton abundance; at these sites, diatoms and Cryptophyte algae generally were dominant (appendix 4).

The highest cyanobacterial abundances in the Republican, Big Blue, and Delaware Rivers occurred within the first 2 weeks after reservoir releases were increased (fig. $5 \mathrm{~A}$ ); however, maximum concentrations in the Republican River were higher than at other sites by a factor of about 10 and exceeded the 20,000 cells/mL guidance level used by KDHE to issue public health advisories. Seasonal patterns in cyanobacterial abundance were unique to individual sites. In the Republican River, cyanobacterial abundance generally declined throughout the course of the study period and cyanobacteria were absent from the phytoplankton community after October 11, 2011. By comparison, in the Delaware River, cyanobacteria peaked on September 8, 2011, were absent from the phytoplankton community between September 11 through September 26, 2011, and then persisted through the end of the study period (fig. $5 A, B$ ).

Microcystis was the dominant (greater than 50 percent of total cyanobacterial abundance) cyanobacterial genera in the Republican River for most of the study period (appendix 3). By comparison, though Microcystis was present downstream from other reservoirs, multiple genera typically were co-dominant. Microcystis was not present in the Smoky Hill River during the study period. The relative abundance of cyanobacteria and the predominance of Microcystis in the Republican River relative to other tributary sites reflected the ongoing Microcystis bloom in Milford Lake during the study period (appendix 3).

\section{Cyanobacteria in the Kansas River Main Stem}

On September 2, 2011, streamflow was peaking at Belvue, but water released from Milford and Tuttle Creek Lakes had not yet reached Topeka; therefore, water-quality conditions at sites located downstream from Belvue (fig. 1) may be indicative of Kansas River water-quality conditions before reservoir releases. On September 2, 2011, cyanobacteria represented between 15 and 59 percent of total phytoplankton abundance upstream from Belvue and Microcystis was the dominant (greater than 88 percent of cyanobacterial abundance) cyanobacterial genera at all sites. By comparison, cyanobacteria were present at all Kansas River main-stem sites downstream from Belvue, but represented less than 8 percent of total phytoplankton abundance (fig. 5C,D). Chroococcus and Pseudanabaena, genera commonly found in riverine ecosystems (Wehr and Sheath, 2003), generally were most abundant; however, Microcystis also was present and the dominant cyanobacterial genera at some sites (appendixes 3 and 4). Thus, cyanobacteria likely were present, and may have been affected by upstream reservoirs, in the Kansas River main stem before increased reservoir releases. On September 8, 2011, reservoir releases had reached Kansas City (I-435 site), and Microcystis was the dominant cyanobacterial genera (greater than 80 percent of cyanobacterial abundance) at all sites (appendixes 3 and 4).

In general, cyanobacterial abundance was highest at all sites on September 2 and 8, 2011 immediately following reservoir releases (fig. $5 \mathrm{C}$ ). Cyanobacterial abundance equalled or exceeded the 20,000 cells $/ \mathrm{mL}$ guidance level used by KDHE to issue public health advisories at Ft. Riley and Belvue on September 2, 2011. Cyanobacterial abundance remained low (less than 1,000 cells $/ \mathrm{mL}$ ) and often were not present in phytoplankton samples after September 12, 2011 (fig. 5C, D). EWI sampling techniques are most representative of the water-quality conditions at a given sample location (U.S. Geological Survey, 2006). As indicated by the spatial variability in cyanobacterial abundance along cross-sectional transects (fig. 3), the absence of cyanobacteria in surface-dip phytoplankton samples does not necessarily mean they were not present at a given site.

With the exception of Ft. Riley on September 2, 2011, the cyanobacteria never dominated (greater than 50 percent of total abundance) the phytoplankton community at Kansas River main-stem sites and typically represented less than 20 percent of the overall community (fig. $5 D$ ). Diatoms were dominant (greater than 70 percent of total abundance) most of the time at Kansas River main-stem sites. Microcystis typically was the dominant (greater than 80 percent of total cyanobacterial abundance) cyanobacterial genera at Kansas-River main-stem sites following reservoir releases; however, Aphanizomenon and Anabaena also were occasionally dominant (appendixes 3 and 4).

\section{Cyanotoxins}

Cyanotoxins are chemically and bioactively diverse (Sivonen, 1996; Carmichael, 1997) and target fundamental cellular processes, thereby affecting a wide range of organisms (Falconer, 1993; Christofferson, 1996), including humans. Cyanotoxins generally are classified into three main groups based on the toxic mechanism in humans: hepatotoxins (effect the liver), such as cylindrospermopsin and microcystin; neurotoxins (effect the central nervous system), such as anatoxin and saxitoxin, and dermatoxins (effect the skin and mucous membranes; Chorus and Bartram, 1999). Although 

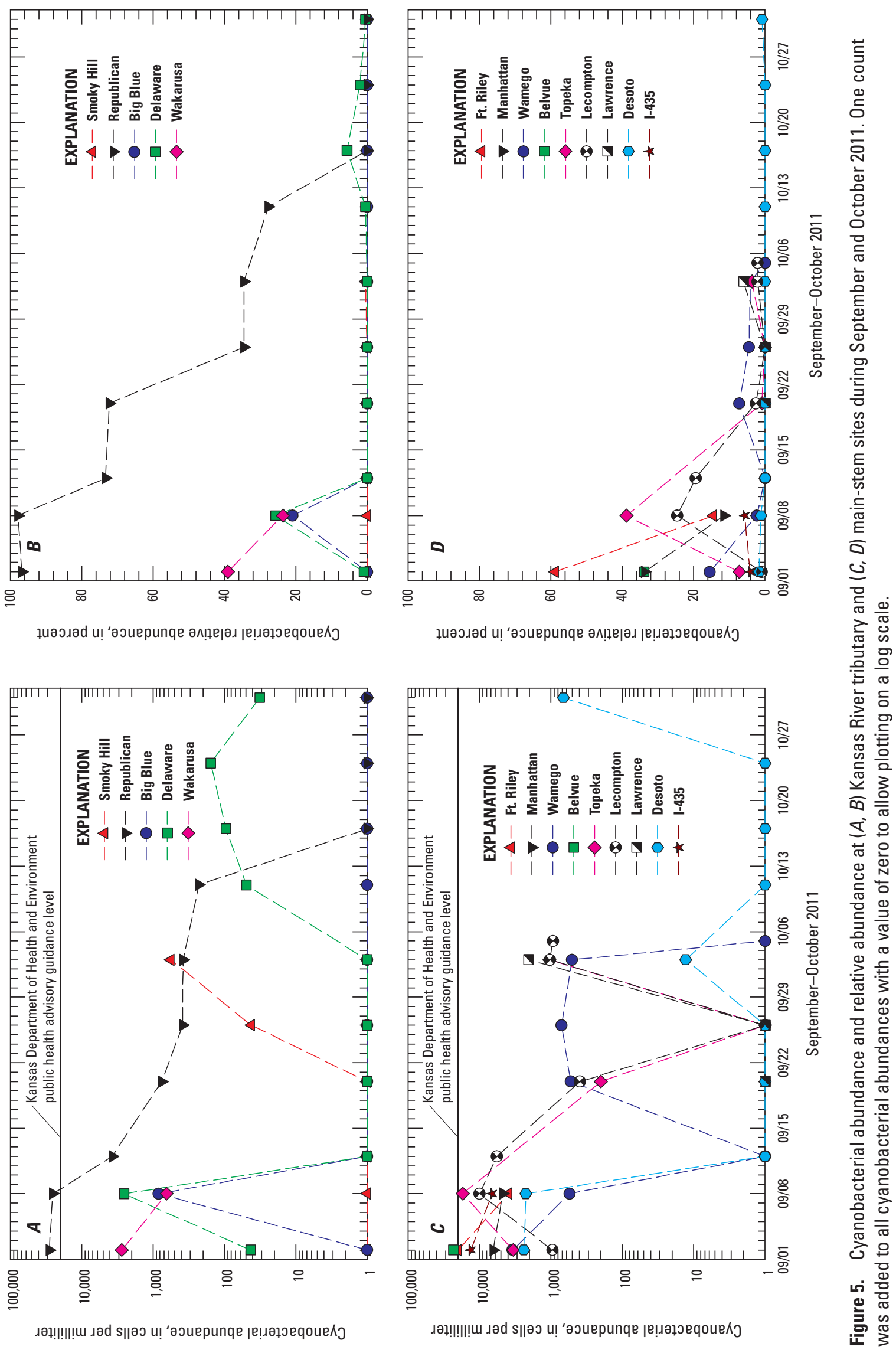
the adverse health effects caused by contact with, or ingestion or inhalation of, high concentrations of cyanotoxins (acute exposure) are well documented, the effects of exposure to low concentrations of cyanotoxins for an extended period of time (chronic exposure) are not as well understood, but may include neurodegenerative disease, tumor promotion, carcinogenicity, and mutagenicity (Chorus and Bartram, 1999; Graham and others, 2008).

Cylindrospermopsin, microcystin, and saxitoxin have been detected in Kansas reservoirs, and potential anatoxin producers are common in cyanobacterial communities (Graham and others, 2010). Anatoxin-a, cylindrospermopsin, microcystin, and saxitoxin were analyzed in samples collected on September 2, 2011, but microcystin was the only cyanotoxin detected; therefore, microcystin was the only cyanotoxin analyzed in all subsequent samples.

\section{Milford Lake Cyanobacterial Bloom}

Milford Lake was the only reservoir in the study area with an ongoing cyanobacterial bloom during reservoir releases and was, therefore, sampled more intensively than other reservoirs. Microcystis, a known microcystin producer, was the only algae present in surface accumulations of cyanobacteria several meters upstream from the Milford Lake Dam on September 2, 2011. The abundance of Microcystis was 600 million cells $/ \mathrm{mL}$ and total microcystin concentration was $150,000 \mu \mathrm{g} / \mathrm{L}$ (appendixes 2 and 3). Spatial variability is characteristic of cyanobacterial blooms, and abundance and concentration of cyanobacteria and cyanotoxins may change by several orders of magnitude within a few meters (Carmichael and Gorham, 1981; Lanaras and others, 1989; Kotak and others, 2000); therefore, results from a single sample location are not necessarily representative of the entire water body.

Total microcystin samples were collected several meters upstream from the Milford Lake Dam for several weeks in September and October 2011 (fig. 6). Total microcystin concentrations were 650 to 7,500 times higher than the KDHE guidance level for a public health warning until September 20,2011. Total microcystin concentrations decreased from 13,000 $\mu \mathrm{g} / \mathrm{L}$ on September 20, 2011 to less than $1 \mu \mathrm{g} / \mathrm{L}$ on September 26, 2011 (fig. 6). The orders of magnitude change in total microcystin concentration for the 7-day period between September 20 and September 26, 2011, demonstrates the extreme temporal variability characteristic of cyanotoxin concentrations. The sharp decline may have been caused by dispersal of the surface accumulation throughout the water column, the surface accumulation being blown to another location, or an overall decline in the bloom resulting in cyanobacteria settling out of the water column (Chorus and Bartram, 1999; Graham and others, 2008).

Milford Lake is a bottom release reservoir (U.S. Army Corps of Engineers, 2011), and outflow waters may not be representative of the entire water column (Thornton, 1990). To compare surface accumulation and outflow conditions, several

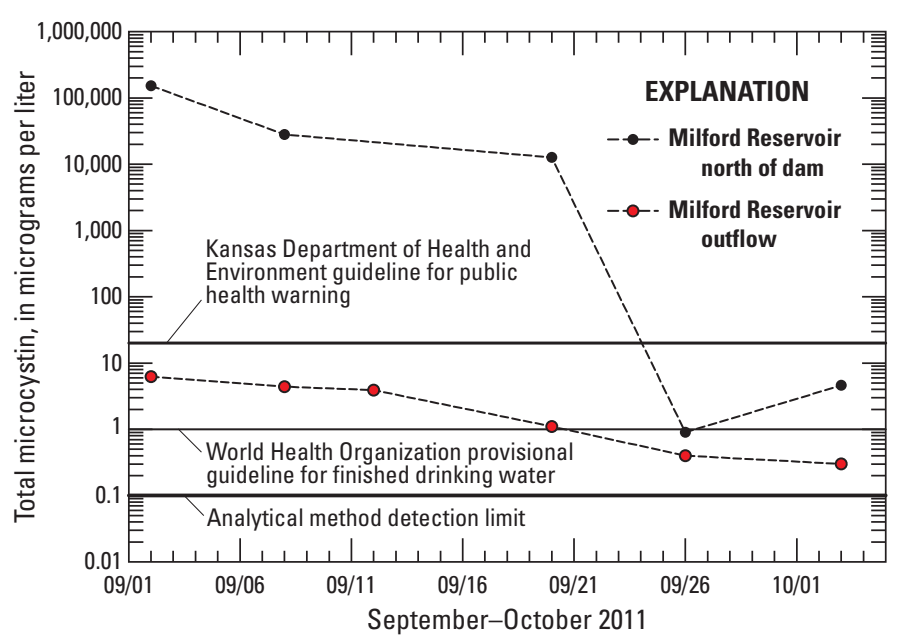

Figure 6. Total microcystin concentrations in Milford Lake upstream (north) from the dam and the Milford Lake outflow during September and October 2011.

samples were collected as close to the Milford Lake outlet structure as possible. On September 2, 2011, cyanobacterial abundance $(28,000$ cells $/ \mathrm{mL})$ and total microcystin concentration $(6.2 \mu \mathrm{g} / \mathrm{L})$ in the Milford Lake outflow were less than 1 percent of the concentrations observed in surface accumulations. Total microcystin concentrations in the Milford Lake outflow generally were less than 10 percent of the concentration in surface accumulations, and never exceeded the KDHE guidance level for a public health warning (fig. 6); therefore, reservoir concentrations of cyanobacteria and associated compounds were not necessarily indicative of outflow concentrations. The low microcystin concentration in Milford Lake outflows relative to surface accumulations indicates that a large part of the cyanobacterial bloom may have been retained in the reservoir. Because cyanobacteria are able to regulate buoyancy and maintain a position near the water surface (Reynolds and Walsby, 1975; Reynolds, 1987; Humphries and Lyne, 1998), cyanobacteria may have been retained on shorelines as reservoir water-surface elevations declined rather than being mixed through, or sedimenting out of, the water column; observations of accumulations of cyanobacteria on the Milford Lake shoreline by field personnel support this hypothesis. The fate and transport of cyanobacteria and associated toxins and taste-and-odor compounds in lakes and reservoirs, however, have not been well described, and studies are needed to quantify the fate of cyanobacteria and associated compounds during the decline of large blooms.

Collecting samples directly from reservoir outflows is not always practical, and may present challenges when continuous water-quality data are desired. For example, hyper-aeration of Milford Lake outflow waters interfered with the performance of optical sensors during September and October 2011 (appendix 2). Therefore, microcystin and chlorophyll data (the only two variables with enough data for a meaningful comparison) collected at the Milford Lake outflow and 4.8 miles 
downstream at the long-term USGS streamflow-gaging station on the Republican River at Junction City (fig. 1) were compared. In general, microcystin and chlorophyll concentrations at the two sites were similar based on a simple linear regression (Helsel and Hirsch, 2002) [coefficient of determination $\left(R^{2}\right)=0.94$ and 0.91 , respectively; all $n=6$ ], indicating that sampling directly at the reservoir outflow did not confer a substantial advantage compared to sampling farther downstream.

\section{Microcystin in Kansas River Tributaries}

The Republican River, downstream from Milford Lake, was the only tributary with detectable microcystin concentrations throughout the study period. Microcystin was detected periodically in the Big Blue and Delaware Rivers, downstream from Tuttle Creek and Perry Lakes, respectively (fig. 1), but concentrations were low (less than or equal to $0.30 \mu \mathrm{g} / \mathrm{L}$ ). Microcystin was not detected in the Smoky Hill River, upstream from the confluence with the Republican River, or in the Wakarusa River, downstream from Clinton Lake (appendix 2).

Total microcystin concentrations in the Republican River ranged from 0.17 to $7.4 \mu \mathrm{g} / \mathrm{L}$ (median: $0.36 \mu \mathrm{g} / \mathrm{L}, n=10$ ), and were greater than $1 \mu \mathrm{g} / \mathrm{L}$ from September 2 through September 26, 2011; however, concentrations never exceeded the KDHE guidance level for a public health warning. After September 26, 2011, low concentrations (less than $0.5 \mu \mathrm{g} / \mathrm{L}$ ) persisted in weekly samples until the end of the study (fig. 7). Temporal patterns in microcystin concentration generally matched patterns in cyanobacterial abundance (fig. 5); however, microcystin was detected for several weeks in October when cyanobacteria were no longer present. Because microcystin was still detected in the Republican River when weekly sampling concluded, samples for total microcystin analysis were collected when routine site visits were made from November 2011 through January $2012(n=4)$. Microcystin was still detected $(0.20 \mu \mathrm{g} / \mathrm{L})$ on November 7 , but was not detectable (less than $0.1 \mu \mathrm{g} / \mathrm{L}$ ) in later samples (data available from

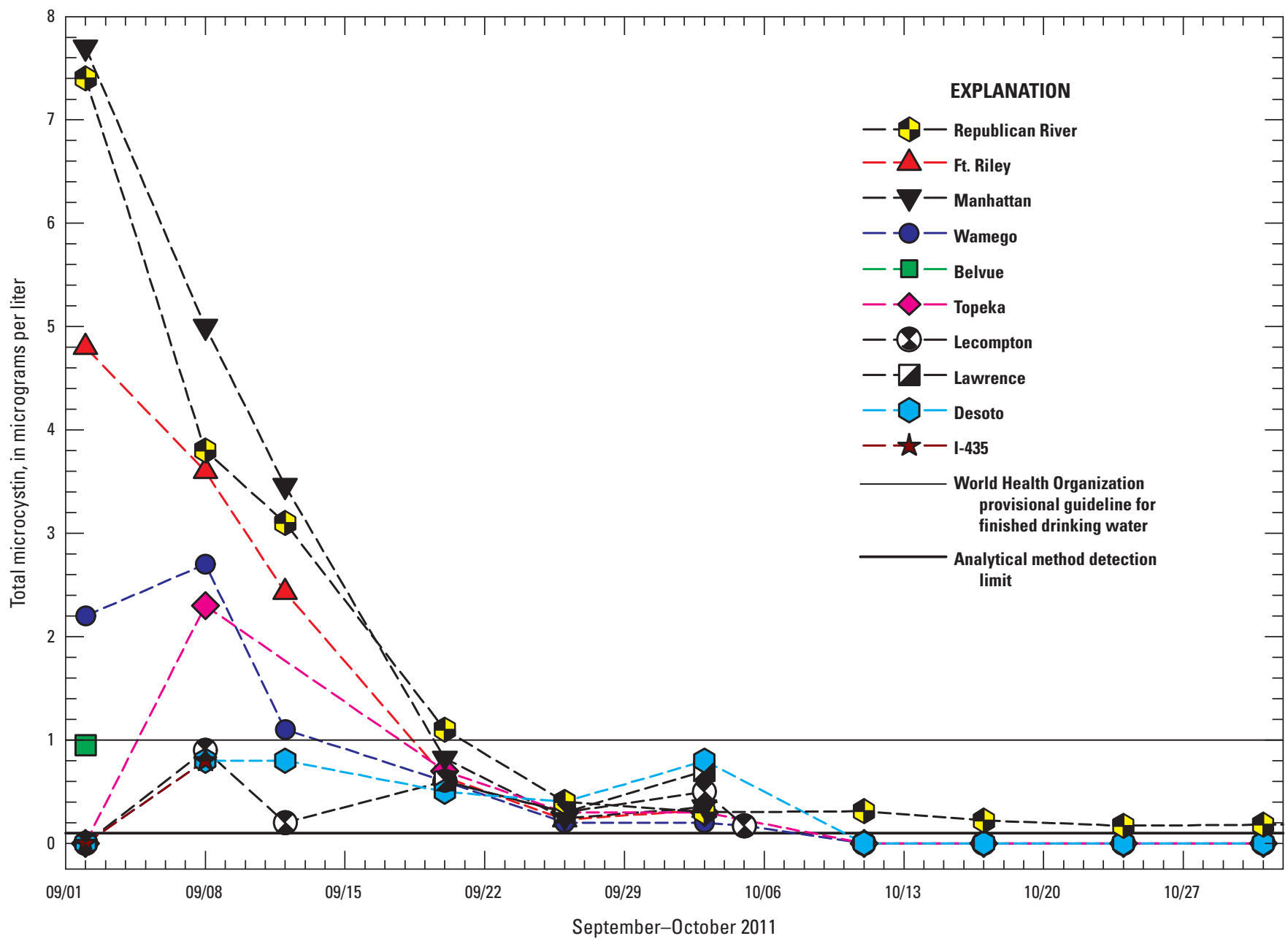

Figure 7. Total microcystin concentrations in the Republican River, downstream from Milford Lake, and Kansas River main-stem sites during September and October 2011. 
the USGS National Water Information System website, http:// waterdata.usgs.gov/nwis).

Based on total microcystin concentrations and daily mean streamflows at the Republican River site, total microcystin loads from Milford Lake on sampled days ranged from about 0.1 to 30 kilograms per day ( $\mathrm{kg} / \mathrm{d}$; fig. 8). Few studies have quantitatively described the downstream transport of cyanobacteria and associated compounds from reservoirs, and minimal data on microcystin loads are available for comparison. Collecting data on microcystin loads will help document transport and provide useful information when describing downstream effects of transport on water use, water-quality conditions, and ecosystem processes such as bioaccumulation (Lehman and others, 2005; Kann and others, 2010; Miller and others, 2010).

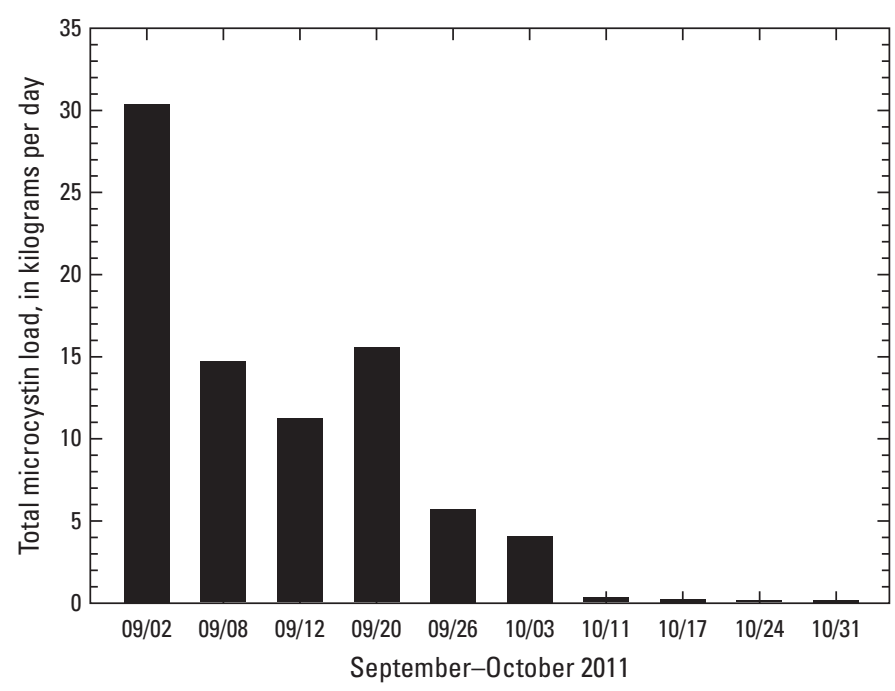

Figure 8. Total microcystin loads from Milford Lake on sampled days during September and October 2011.

\section{Microcystin in the Kansas River Main Stem}

On September 2, 2011, microcystin was not detected at any of the Kansas River main-stem sites downstream from Belvue (fig. 7), suggesting that microcystin may not have been present in the Kansas River main stem before reservoir releases, even though Microcystis was present at most sites on this date (appendix 3). By September 8, 2011, releases from Milford Lake had reached Kansas City (I-435 site), and microcystin was detected at all Kansas River main-stem sites (fig. 7). Temporal patterns in total microcystin concentrations in the Kansas River generally matched patterns in the Republican River, with the highest concentrations occurring immediately following the onset of releases from Milford Lake (fig. 7). Microcystin concentrations exceeded $1 \mu \mathrm{g} / \mathrm{L}$ at Kansas River main-stem sites upstream from Topeka during September 2 through September 12, 2011, when concentrations in the Republican River were greater than $3 \mu \mathrm{g} / \mathrm{L}$; total microcystin concentrations at Kansas River main-stem sites downstream from Topeka never exceeded $1 \mu \mathrm{g} / \mathrm{L}$. Microcystin was detected at all Kansas River main-stem sites until October 5, 2011. After October 5, microcystin was no longer detected in the Kansas River even though it was still detected in the Republican River (fig. 7), possibly because reservoir releases were substantially lower (fig. 2). Patterns in microcystin occurrence and concentration at Kansas River tributary and main-stem sites indicate that Milford Lake was the source of microcystin in the Kansas River.

In general, total microcystin concentrations in the Kansas River decreased in the downstream direction (fig. 7); however, one notable exception did occur. During September 2 through September 12, 2011, the highest total microcystin concentrations occurred at Manhattan (fig. 7), about 26 miles downstream from the confluence of the Smoky Hill and Republican Rivers and about 21 miles downstream from Ft. Riley (fig. 1). Concentrations at Manhattan were about 4 to 27 percent higher than in the Republican River, and 33 to 46 percent higher than at Ft. Riley. This result may indicate that cyanobacterial populations were growing in the Kansas River between the confluence of the Smoky Hill and Republican Rivers and Manhattan, but should be interpreted with caution given the potential spatial variability along crosssectional transects (fig. 3). Reservoirs may have substantial effects on phytoplankton community composition in rivers and cyanobacteria may persist farther downstream than some other algal groups (Reynolds, 1984; Allan, 1995; Wehr and Sheath, 2003). Although downstream microcystin transport from reservoir outflows has not been well studied, data collected in the Middle Klamath River Basin, Oregon and California, also may indicate an initial increase in microcystin concentrations downstream from the outflow of Iron Gate Reservoir, California (Kann and others, 2010).

\section{Microcystin in Treated Drinking Water}

Efficacy of cyanotoxin removal during drinking-water treatment processes depends on the cyanotoxin(s) present and the type of treatment process and maintenance. In general, most modern drinking-water treatment facilities reduce cyanotoxin concentrations, and acute illness from drinking-water exposure is uncommon (Chorus and Bartram, 1999; Westrick and others, 2010). The WHO has developed a provisional guideline of $1 \mu \mathrm{g} / \mathrm{L}$ for microcystin in finished drinking water that has been adopted by several countries worldwide (Chorus and Bartram, 1999; Hudnell, 2008). Microcystin was not detected in five finished drinking-water samples collected on September 8 and September 20, 2011, at drinking-water treatment facilities that use the Kansas River as a source-water supply (data on file). These samples do not necessarily characterize conditions in finished drinking-water during the study period, and do not provide information on individual steps in the treatment process. Studies designed specifically to evaluate the efficacy of cyanotoxin removal at drinking-water treatment 
facilities that use the Kansas River as a source supply are needed for a more quantitative evaluation.

The chemical composition of drinking water, including free chlorine and metal ions, may interfere with the quantitation of microcystin (Oliveira and others, 2005). Chemical quenching of chlorine generally is recommended before cyanotoxin analysis using bioassays, but the type of chemical depends on the assay being used (Froscio and others, 2010). Sodium thiosulfate, sodium sulfate, and ascorbic acid have traditionally used as quenching agents; however, these chemicals are reducing agents and may reduce the analytes or interfere with analytical methods. This issue requires a significant research effort to resolve and is an area of needed research. Finished drinking-water samples collected as part of this study were frozen as soon as possible after collection, but no chemicals were added to quench the effects of chlorine and the potential effects on ELISA results are unknown. More research on the analysis of cyanotoxins in finished drinkingwater samples is required to fully understand the effects of chemical composition on analytical results, but available data indicate that drinking-water samples should be processed and analyzed differently than surface-water samples.

\section{Taste-and-Odor Compounds}

Biological activity associated with naturally occurring algae in source water is among the most common causes of tastes and odors in finished drinking water. The taste-andodor causing compounds geosmin and MIB cause earthy and musty tastes and odors and are detectable by humans at low concentrations (human detection threshold of 5 to 10 nanograms per liter, ng/L). Most taste-and-odor problems associated with geosmin and MIB are caused by cyanobacteria, but bacteria in the actinomycetes group also may produce these compounds (Taylor and others, 2005). Unlike cyanobacteria, the actinomycetes bacteria are not photosynthetic and are not part of phytoplankton communities. The actinomycetes bacteria typically are terrestrial organisms associated with soils; taste-and-odor compounds from these bacteria typically are produced terrestrially and washed into aquatic ecosystems. Currently (2012), it is unknown if or for how long terrestrial actinomycetes bacteria remain metabolically active in aquatic environments (Zaitlin and others, 2003; Zaitlin and Watson, 2006). Actinomycetes bacteria were not analyzed as part of this study because of the focus on cyanobacteria and reservoir releases and substantial runoff events did not occur during the study period (fig. 2).

\section{Geosmin and MIB in Kansas River Tributaries}

Geosmin and MIB were detected in all tributaries located immediately downstream from reservoirs, but not in the Smoky Hill River (fig. 9A, B). The highest total geosmin concentrations occurred in the Republican River downstream from Milford Lake (range: less than 2.0-20 ng/L; median: $8.0 \mathrm{ng} / \mathrm{L} ; n=10)$, and concentrations were more than the human detection threshold ( 5 to $10 \mathrm{ng} / \mathrm{L}$ ) until October 11 , 2011. The Delaware River, downstream from Perry Lake, was the only other tributary that had total geosmin concentrations more than the human detection threshold (range: less than 2.0-11 ng/L; median: $4.6 \mathrm{ng} / \mathrm{L} ; n=10)$ during September and October, 2011 (fig. 9A). Total geosmin concentrations exceeded the human detection threshold in the Delaware River on October 11 through October 24, 2011. There were no clear temporal patterns in geosmin occurrence and concentration in the Kansas River tributaries (fig. 9A); however, patterns in the Republican and Delaware Rivers generally matched temporal patterns in cyanobacteria (fig. 5).

MIB was most common in the Big Blue River, downstream from Tuttle Creek Lake, and the Delaware River (fig. 9B). Total MIB concentrations in the Big Blue River were low (range: less than 2.0-7.7 ng/L; median $3.8 \mathrm{ng} / \mathrm{L}$; $n=10$ ), and only exceeded the human detection threshold on one occasion during the study period (fig. 9B). Concentrations in the Delaware River (range: less than 2.0-29 ng/L; median: $7.6 \mathrm{ng} / \mathrm{L} ; n=10)$ exceeded the human detection threshold from September 2 through September 26, 2011 (fig. 9B). Unlike geosmin, general temporal patterns in MIB occurrence and concentration were evident, but varied by river and did not necessarily match temporal patterns in cyanobacteria (figs. 5 and $9 B$ ). In general, MIB was detectable in the Big Blue River for most of the study period and fluctuated by less than a factor of two. Total MIB concentrations in the Delaware River peaked on September 8, 2011 and declined to concentrations below the analytical detection limit by October 17, 2011 (fig. 9B).

\section{Geosmin and MIB in the Kansas River Main Stem}

On September 2, 2011, geosmin was detected in the Republican River and at all Kansas River main-stem sites downstream to Belvue (figs. 1 and 9A, C). Geosmin was not detected in the Kansas River downstream from Belvue, indicating that geosmin may not have been present in the Kansas River main stem before reservoir releases. By comparison, MIB was not detected at any Kansas River main-stem sites except Lecompton (fig. 9D), immediately downstream from the confluence with the Delaware River (fig. 1), which indicates either the reservoir was affecting water-quality at the Lecompton site before increased reservoir releases or the compound was being produced in the Kansas River at this site. By September 8, 2011, geosmin was detected at all Kansas River main-stem sites and MIB was detected at most mainstem sites, with the exception of Manhattan and Wamego (fig. $9 C, D$ ).

Temporal patterns in geosmin and MIB concentrations in the Kansas River were more consistent than in tributaries. Total geosmin concentrations had similar temporal patterns at 

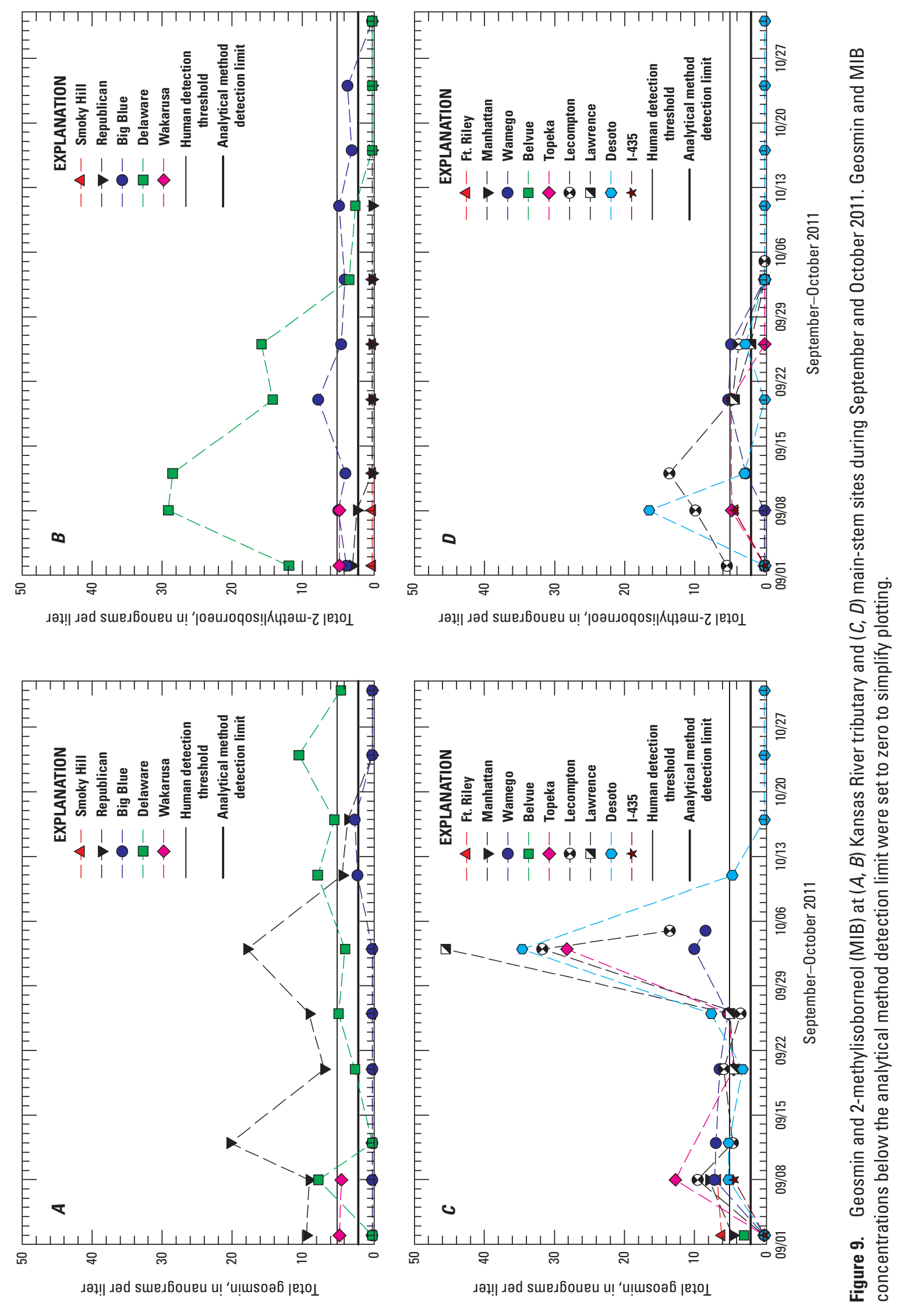
all main-stem sites and peaked on October 3, 2011; concentrations at all Kansas River main-stem sites exceeded the human detection threshold (5 to $10 \mathrm{ng} / \mathrm{L}$ ) on this date, with the highest concentrations occurring downstream from Wamego (greater than or equal to $28 \mathrm{ng} / \mathrm{L}$; fig. 9 C). Geosmin was not detected in the Kansas River at De Soto (the only Kansas River mainstem site sampled after October 5, 2011) after October 11, 2011. Temporal patterns in MIB were more variable among sites, but in general concentrations peaked in mid-September and were no longer detectable in October (fig. 9D).

Spatial patterns in geosmin and MIB concentrations at Kansas River main-stem sites are more complex than spatial patterns in total microcystin concentration (figs. 7 and 9), possibly because multiple tributaries contributed taste-and-odor compounds to the Kansas River. Data also suggest geosmin and MIB also may have been produced in the Kansas River, but this result should be interpreted with caution given the potential spatial variability in these compounds along crosssectional transects (fig. 3). Total geosmin concentrations at the Kansas River main-stem sites downstream from Wamego on October 3, 2011, exceeded the maximum concentration observed in the tributaries ( $20 \mathrm{ng} / \mathrm{L})$ by 33 to 49 percent. Similarly, on September 8, 2011, total MIB concentration at De Soto was 50 percent higher than at Lecompton, located about 33.5 miles upstream (fig. 1), and 90 percent higher than in the Wakarusa River, located about 10.5 miles upstream (fig. 9; appendix 2).

\section{Co-Occurrence of Cyanotoxins and Taste-and-Odor Compounds}

Cyanotoxins and taste-and-odor compounds present challenges to drinking-water treatment, though optimal treatment may vary depending on the compound or mixture of compounds present (Westrick and others, 2010). With multiple potential producers for most compounds (Graham and others, 2008), co-occurrence of cyanotoxins and taste-and-odor compounds in cyanobacterial blooms can be expected; however, few studies have addressed the frequency of co-occurrence. In a study of 23 cyanobacterial blooms in the Midwestern United States, cyanotoxins and taste-and-odor compounds co-occurred in 91 percent of blooms, indicating co-occurrence may be common (Graham and others, 2010); therefore, cooccurrence was evaluated in samples collected from Kansas River tributary and main-stem sites during September and October 2011.

During September and October 2011, taste-and-odor compounds were detected more frequently in Kansas River tributary and main-stem sites ( 80 percent of samples, $n=80$ ) than was microcystin (61 percent of samples, $n=95$ ); and geosmin (68 percent of samples) was more common than MIB (46 percent of samples). Only 16 percent of samples collected did not have either detectable microcystin or taste-and-odor concentrations. Overall, microcystin and taste-and-odor compounds co-occurred in 56 percent of samples that were analyzed for both compounds $(n=80)$, indicating co-occurrence was common during this study (fig. 10). Of the samples with detectable microcystin $(n=48)$, only 8 percent did not have detectable taste-and-odor compounds. Conversely, of the samples with detectable taste-and-odor compounds $(n=63)$, about 30 percent did not have detectable microcystin. Therefore, taste-and-odor may be used as an indicator that cyanotoxins may be present; however, microcystin did occasionally occur without taste-and-odor, so odor alone does not provide sufficient warning to ensure human-health protection.

Despite frequent co-occurrence, the spatial and temporal patterns in microcystin, geosmin, and MIB were unique for individual compounds and did not necessarily match patterns in cyanobacterial abundance (figs. 5, 7, and 9). Production of cyanotoxins and taste-and-odor compounds is straindependent, rather than species-dependent, and some strains may produce multiple compounds simultaneously. Although these compounds may be produced simultaneously by some strains, they are not produced by the same biogeochemical

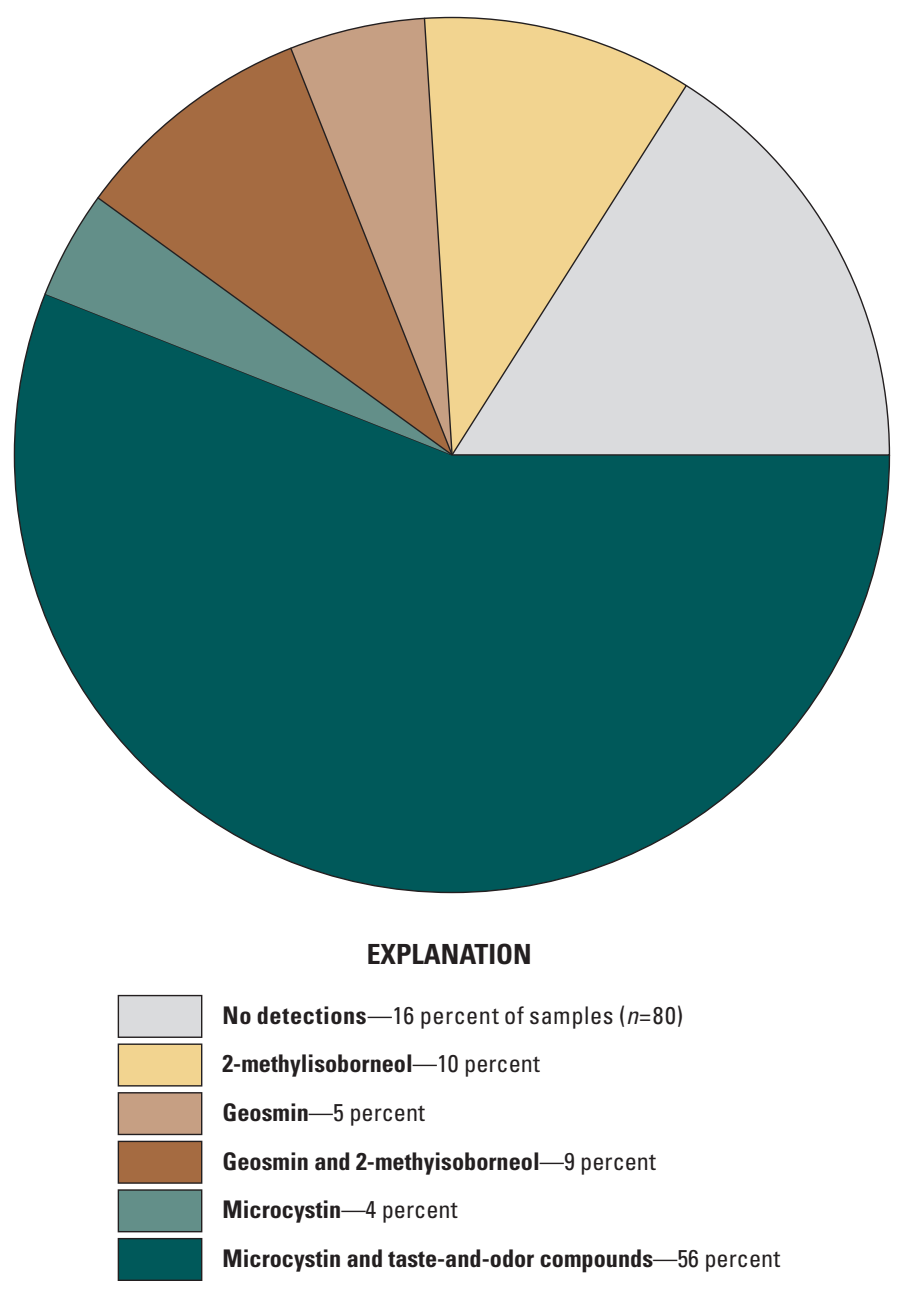

Figure 10. Co-occurrence of microcystin and taste-and-odor compounds in Kansas River samples $(n=80)$ during September and October 2011. 
pathways and production of each compound may be regulated by a different set of environmental conditions (Chorus and Bartram, 1999; Taylor and others, 2005). Additionally, in a mixed cyanobacterial assemblage, different compounds may be produced by different members of the community. All compounds should be studied for a comprehensive understanding of spatiotemporal dynamics and transport. Use of a single compound or cyanobacterial abundance cannot necessarily be used as an indicator of the presence or concentration of other compounds.

\section{Fate and Transport of Cyanobacteria and Associated Toxins and Taste-and- Odor Compounds in the Kansas River}

Fate and transport of cyanobacteria and associated toxins and taste-and-odor compounds in the Kansas River were described by comparing measured concentrations of cyanobacteria, microcystin, and taste-and-odor compounds at Kansas River main-stem sites to expected concentrations if dilution was the only factor influencing the fate and transport. This approach assumes that tributaries downstream from reservoirs are the only source of cyanobacteria and associated compounds in the Kansas River. Simple dilution models (Hem, 1985) were calculated on four dates when streamflow conditions were stable for 48 hours before sample collection (September 8, 2011; September 26, 2011; October 3, 2011; and October 31,2011). On October 31, 2011, few sites were sampled and concentrations of cyanobacteria and associated compounds were low or not detected (appendixes 2 and 3); measured and expected concentrations at all Kansas River main-stem sites were less than the analytical detection limit. Therefore, only results from September 8, 2011, September 26, 2011, and October 3, 2011 are described in detail.

On September 8, 2011, cyanobacterial abundance at most Kansas River main-stem sites was less than expected based on dilution alone (fig. 11A). Topeka (river mile 83.8; fig. 1, table 1) was the only site where measured abundance was higher than expected abundance. At all other sites, the measured abundance was between 12 and 183 percent less than expected abundance (median: 120 percent, $n=6$ ). Measured cyanobacterial abundance at Wamego (river mile 128.3; fig. 1, table 1) on September 26, 2011, was about 78 percent higher than expected based on dilution alone; however, Wamego was the only Kansas River main-stem site with cyanobacteria present and abundance was less than expected at all other sites (fig. $11 B$ ). In contrast to September patterns, cyanobacterial abundance on October 3, 2011 was between 83 and 167 percent higher than expected (median: 136 percent, $n=4$ ) based on dilution alone at all sites except De Soto (river mile 30.8; fig. 1, table 1) (fig. 11C). At De Soto, cyanobacterial abundance was about 173 percent less than expected. Because cyanobacteria have the ability to regulate buoyancy and control their position in the water column (Reynolds, 1987), differential transport of these organisms may occur, and as indicated by cross-sectional transects (fig. 3), measured cyanobacterial abundance at a given sample location may not have been indicative of the entire cyanobacterial community (fig. 11A). In addition, buoyancy may cause cyanobacteria to become trapped in backwaters or eddies in the Kansas River.

Measured total microcystin concentrations upstream from Topeka (river mile 83.8; fig. 1, table 1) on September 8, 2011 were between 33 and 63 percent higher than expected concentrations based on dilution alone (fig. 12A). The largest difference occurred at Manhattan (river mile 149.3; fig. 1, table 1), reflecting the relatively high total microcystin concentrations that occurred at this site in early September (fig. 7). Downstream from Topeka, measured total microcystin concentrations were between 59 and 67 percent less than expected based on dilution alone. A different pattern was observed on September 26, 2011, and October 3, 2011; total microcystin concentrations downstream from Wamego (river mile 128.3; fig. 1, table 1) were between 40 and 128 percent higher than expected based on dilution alone, with concentrations generally increasing downstream (fig. 12B,C).

Measured total geosmin concentrations were more than 25 percent higher than expected concentrations based on dilution at most Kansas River main-stem sites on September 8, 2011, September 26, 2011, and October 3, 2011, with the largest differences (greater than 70 percent) occurring downstream from Wamego (river mile 128.3; fig. 1, table 1) (fig. 13A, C, E). Patterns in measured and expected total MIB concentrations were more variable than geosmin. On September 8, 2011, measured total MIB concentrations were between 61 and 96 percent higher than expected concentrations at Ft. Riley, Topeka, Lecompton, and De Soto (river miles $170.6,83.8,64.3$, and 30.8 , respectively; fig. 1, table 1); measured and expected concentrations were similar (less than 25 percent different) at other sites. The largest differences occurred at Lecompton and De Soto, downstream from the confluence with the Delaware River (fig. 13B). Patterns were substantially different on September 26, 2011, even though total MIB concentrations in tributary streams were similar to those on September 8, 2011. Total MIB concentrations were less than, or similar to, expected concentrations at most sites, with the exception of Wamego, where the measured concentration was about 69 percent higher than the expected concentration (fig. 13D). Measured and expected total MIB concentrations were below the analytical detection limit (less than $2 \mathrm{ng} / \mathrm{L}$ ) at all Kansas River main-stem sites on October 3, 2011 (fig. 13F).

Measured concentrations of cyanobacteria and associated compounds were substantially higher than expected concentrations at some sites and substantially lower at others, though spatial and temporal patterns were unique for individual compounds (figs. 11, 12, and 13). Higher than expected concentrations, coupled with higher microcystin and tasteand-odor concentrations at Kansas River main-stem sites than tributary sites on several occasions (figs. 7 and 9), suggest 


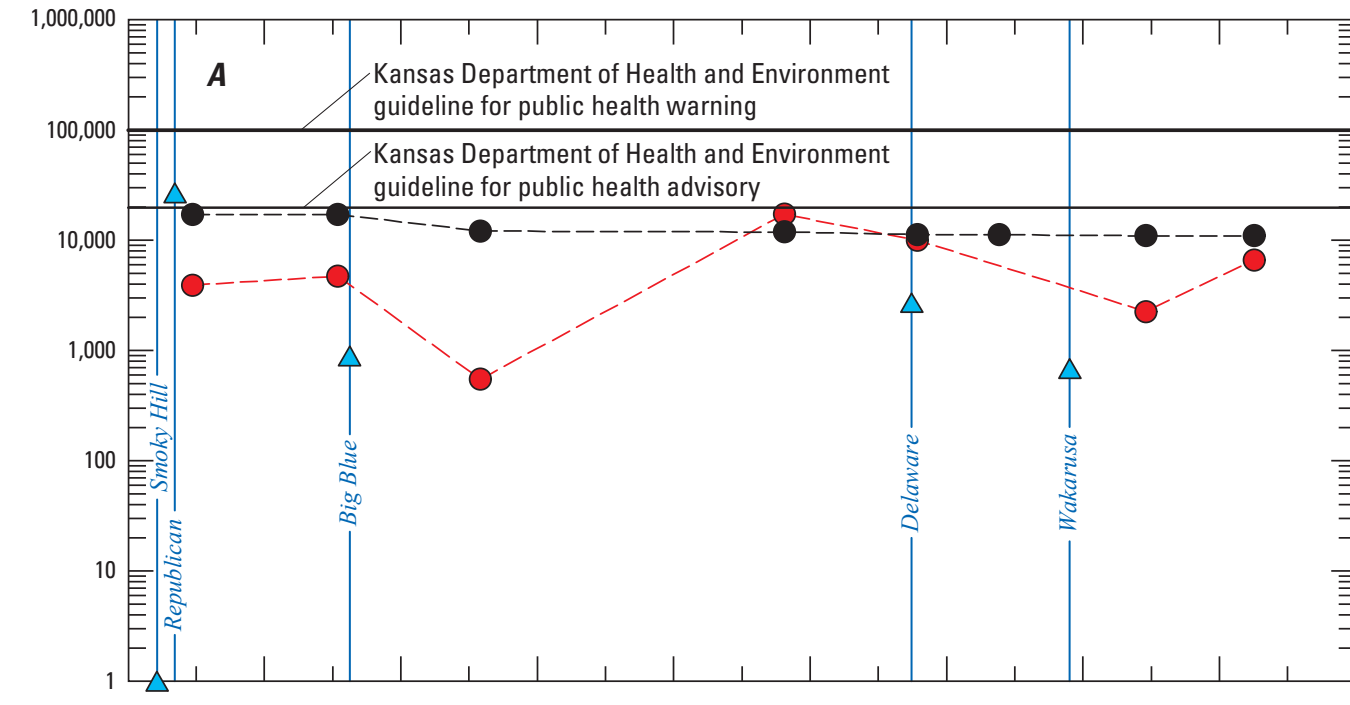

EXPLANATION

$\triangle$ Measured tributary concentration

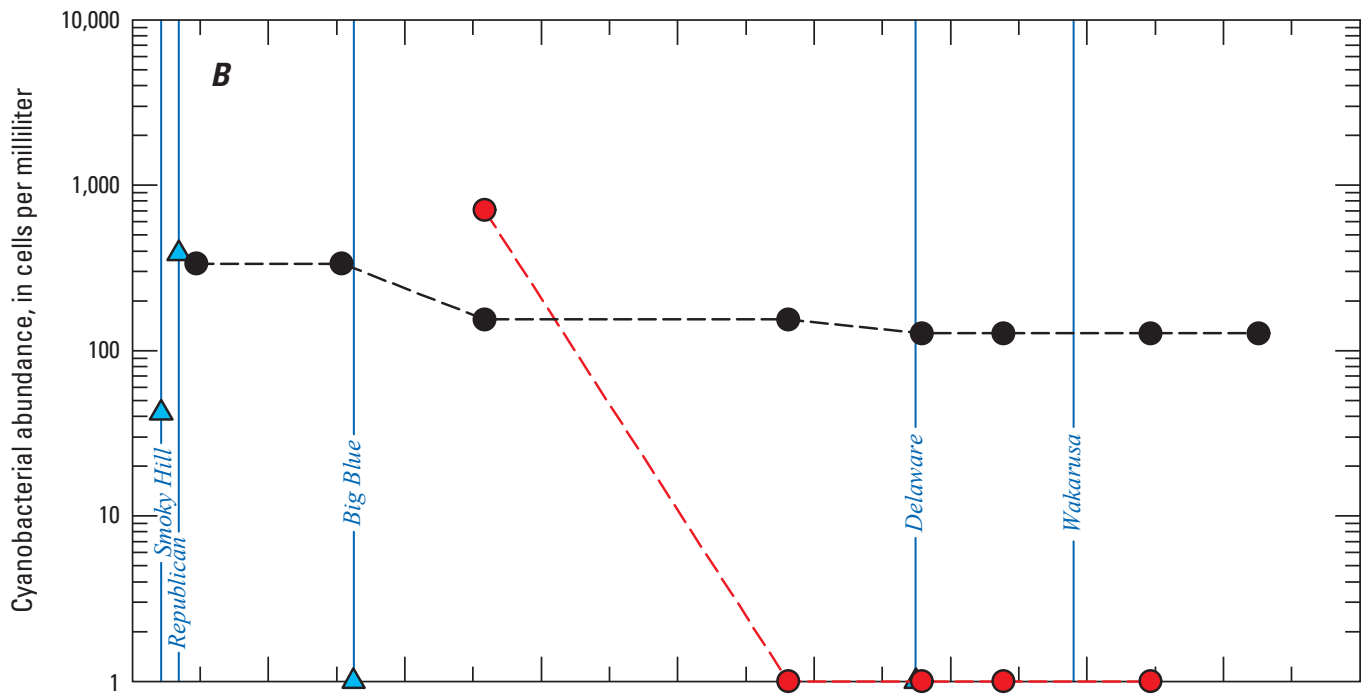

Expected main-stem concentration

Measured main-stem concentration

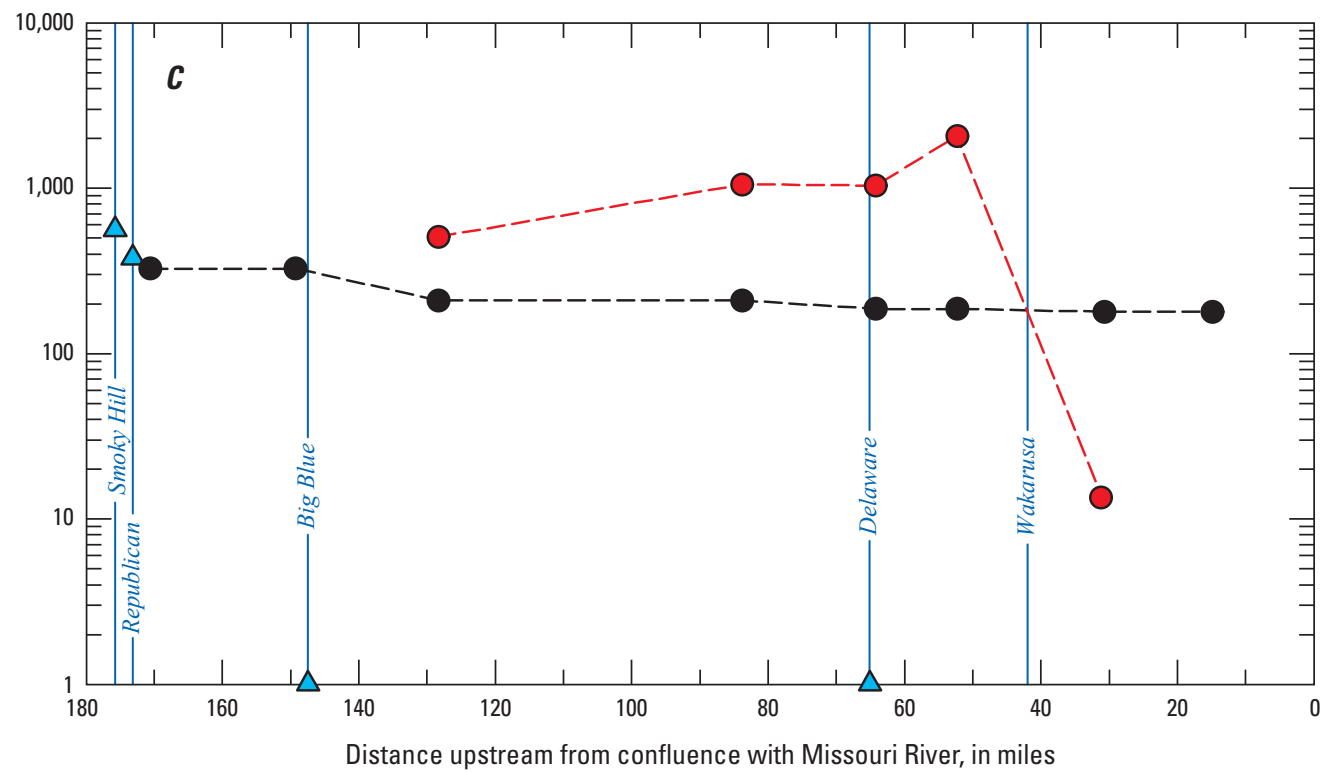

Figure 11. Measured and expected concentrations of cyanobacteria in the Kansas River on $(A)$ September 8, 2011, $(B)$ September 26, 2011, and (C) October 3, 2011, with tributaries labeled. One count was added to all cyanobacterial abundances with a value of zero to allow plotting on a log scale. 

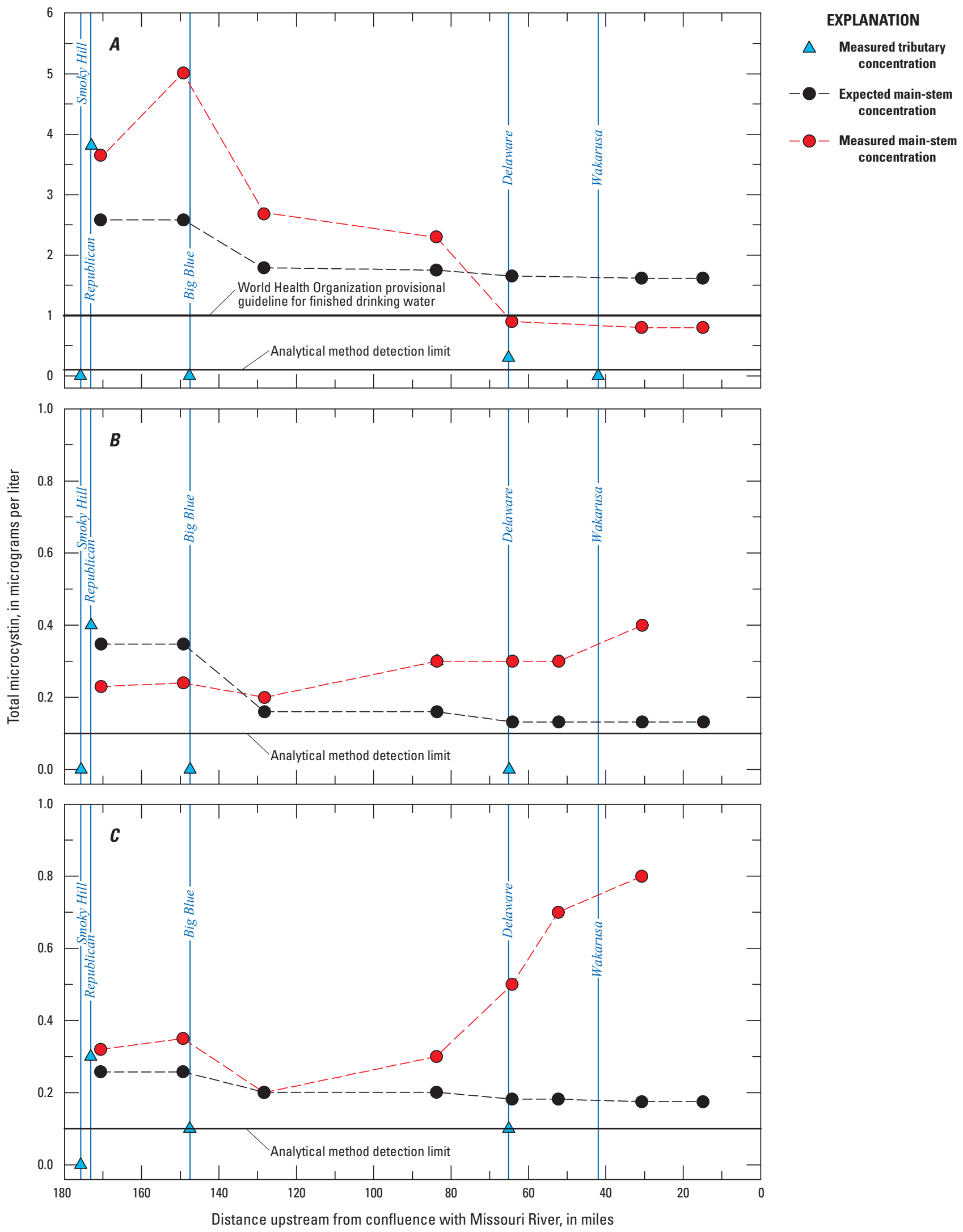

Figure 12. Measured and expected concentrations of total microcystin in the Kansas River on (A) September 8, 2011, $(B)$ September 26, 2011, and (C) October 3, 2011, with tributaries labeled. Microcystin concentrations below the analytical method detection limit were set to zero to simplify plotting. 

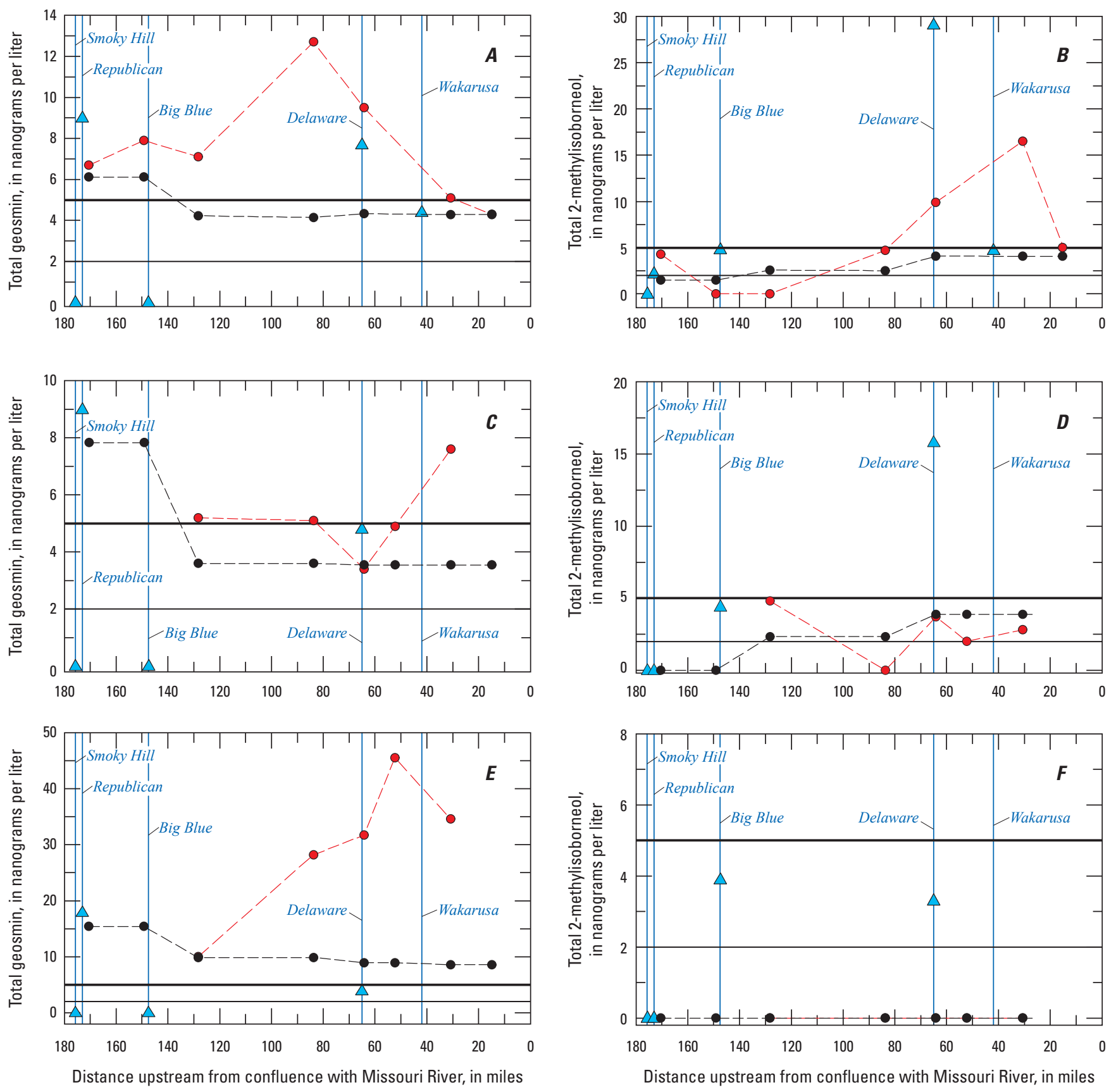

EXPLANATION

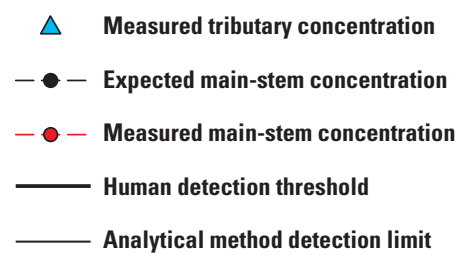

Figure 13. Measured and expected concentrations of geosmin and 2-methylisoborneol (MIB) in the Kansas River on $(A, B)$ September 8, 2011, $(C, D)$ September 26, 2011, and (E, F) October 3, 2011, with tributaries labeled. Measured and estimated geosmin and 2-methylisoborneol concentrations below the analytical method detection limit were set to zero to simplify plotting. 
that cyanobacteria introduced to the Kansas River may have occasionally continued to grow and produce these compounds; however, cyanobacterial abundance at Kansas River mainstem sites was rarely higher than tributary sites and measured abundances commonly were less than expected abundances (figs. 5 and 11, appendix 3). Cyanobacterial toxins and tasteand-odor compounds may occur in particulate (intracellular) and dissolved (extracellular) phases (Graham and others, 2008). During this study, total microcystin concentration was analyzed in most samples, which does not account for the amount of cyanotoxin present in each phase. Dissolved-phase cyanotoxins and taste-and-odor compounds may persist for several days to weeks after the decline of a cyanobacterial population (Jones and Orr, 1994; Heresztyn and Nicholson, 1997; Chiswell and others, 1999; Chorus and Bartram, 1999), and may lead to spatial or temporal uncoupling of cyanobacteria and associated compounds. On September 20, 2011, total and dissolved microcystin were analyzed to evaluate potential for differential transport (appendix 2). Dissolved microcystin contributed between 0 and 40 percent (median: 8 percent; $n=8$ ) to total microcystin concentrations, indicating particulate and dissolved-phase transport mechanisms likely were important in the Kansas River. Studies designed to specifically evaluate the differences between particulate and dissolved-phase transport of cyanotoxins and taste-and-odor compounds are needed to fully characterize the fate and transport of these compounds during reservoir releases.

Data were not collected in such a way to determine whether differences between measured and expected concentrations were statistically significant; however, results indicate that simple dilution models were not sufficient to describe the downstream transport of cyanobacteria and associated compounds in the Kansas River. The environmental fate and downstream transport of cyanobacterial toxins and taste-andodor compounds within natural conditions has not been well studied. There likely are several factors that affect the downstream transport of cyanobacteria and associated compounds, including losses to and gains from groundwater, the potential for cyanobacterial growth and production of cyanotoxins and taste-and-odor compounds, differential transport of particulate and dissolved phases, and potential for sediment sorption and desorption, photolysis, and biodegradation (Westerhoff and others, 2005; Kato and others, 2007; Chen and others, 2008; Wörmer and others, 2010; Wu and others, 2011).

\section{Summary}

Cyanobacteria cause a multitude of water-quality concerns, including the potential to produce toxins and taste-andodor compounds. Toxins and taste-and-odor compounds may cause substantial economic and public health concerns and are of particular interest in lakes, reservoirs, and rivers that are used for drinking-water supply, recreation, or aquaculture. The Kansas River is a primary source of drinking water for about
800,000 people in northeastern Kansas. There are no reports of noticeable cyanobacterial blooms developing in the Kansas River; however, reservoirs in the lower Kansas River Basin do occasionally develop blooms. Water releases from Milford Lake to the Kansas River during a toxic cyanobacterial bloom in late August 2011 prompted concerns about cyanobacteria and associated toxins and taste-and-odor compounds in downstream drinking-water supplies. The purpose of this report is to characterize the fate and transport of cyanobacteria and associated toxins and taste-and-odor compounds in the Kansas River following upstream reservoir releases during September and October 2011. This study is one of the first to quantitatively document the transport of cyanobacteria and associated compounds during a reservoir release and improves understanding of the fate and transport of cyanotoxins and taste-and-odor compounds downstream from reservoirs.

Discrete water-quality samples were collected weekly from surface accumulations of cyanobacteria several meters upstream from the Milford Lake Dam, the Milford Lake outlet, 5 Kansas River tributary sites, and 9 Kansas River mainstem sites during September 2 through October 31, 2011. Most discrete water-quality samples were collected as surface dips from the centroid of flow and analyzed for cyanotoxins, tasteand-odor compounds, and phytoplankton community composition. Several discrete surface-dip and single integrated-vertical samples from cross-channel transects and EWI samples also were collected to describe variability in cyanobacteria, cyanotoxins, taste-and-odor compounds, and sampling techniques.

Understanding the effect of sample location and method is essential to the design of effective monitoring strategies and studies to quantify fate and transport of cyanobacteria and associated compounds. Cyanobacterial abundance varied by as much as a factor of about 5,000 along cross-channel transects. Microcystin, geosmin, and MIB concentrations were less variable; concentrations of these compounds varied by as much as a factor of two along cross-channel transects. A comparison of results from surface-dip, single integrated-vertical, and EWI samples indicates that single integrated-vertical samples at the centroid of flow may be a useful compromise between surface-dip and EWI sampling methods when a rapid approach is needed.

From August 31 through October 5, 2011, releases from Milford, Tuttle Creek, and Perry Lakes were increased to evacuate water that had accumulated in the flood-control pool during flood conditions along the Missouri River. Streamflow at most Kansas River main-stem sites increased by about a factor of 10 during peak reservoir releases. Water gains and losses occurred in the Kansas River depending on reservoir releases and streamflow conditions. Losses to groundwater when streamflows in the Kansas River main stem were increasing indicate the potential for reservoir releases to affect groundwater quality as well as surface-water quality in the lower Kansas River Basin.

Cyanobacteria occasionally were present at all Kansas River tributary sites, but occurred most frequently in the Republican River, downstream from Milford Lake, and in the 
Delaware River, downstream from Perry Lake. The highest cyanobacterial abundances in the Republican, Big Blue (downstream from Tuttle Creek Lake), and Delaware Rivers occurred within the first 2 weeks after reservoir releases were increased; however, maximum concentrations in the Republican River were higher than at other sites by a factor of about 10 and exceeded the 20,000 cells per milliliter guidance level used by the Kansas Department of Health and Environment to issue public health advisories. Cyanobacteria in the Smoky Hill River contributed less than 1 percent to total phytoplankton abundance. The relative abundance of cyanobacteria and the predominance of Microcystis in the Republican River relative to other tributary sites reflect the ongoing Microcystis bloom in Milford Lake during the study period.

Like the tributary sites downstream from reservoirs, cyanobacterial abundance was generally highest at Kansas River main-stem sites during the first 2 weeks following reservoir releases. The KDHE guidance level of 20,000 cells per milliliter was exceeded on September 2, 2011, at Ft. Riley and Belvue. With the exception of Ft. Riley on September 2, 2011, the cyanobacteria never dominated phytoplankton community composition in the Kansas River main stem, and typically represented less than 20 percent of the overall community. Microcystis typically was the dominant (greater than 80 percent of total cyanobacterial abundance) cyanobacterial genera at Kansas-River main-stem sites following reservoir releases; however, Aphanizomenon and Anabaena also were occasionally dominant.

Microcystin was the only cyanotoxin detected in samples collected on September 2, 2011, and was, therefore, the only cyanotoxin analyzed in all subsequent samples. Concentrations of cyanobacteria and associated compounds in Milford Lake were not necessarily indicative of outflow conditions. Total microcystin concentrations in Milford Lake were 650 to 7,500 times higher than the KDHE guidance level for a public health warning (20 micrograms per liter) for most of September 2011. By comparison, total microcystin concentrations in the Milford Lake outflow, generally, were less than 10 percent of the concentration in surface accumulations, and never exceeded the KDHE guidance level for a public health warning. Microcystin and chlorophyll concentrations at the Milford Lake outflow and the Republican River site, located about 4.8 miles downstream, were similar; therefore, sampling directly at the reservoir outflow did not confer a substantial advantage compared to sampling farther downstream.

The Republican River, downstream from Milford Lake, was the only tributary with detectable microcystin concentrations throughout the study period; concentrations ranged from 0.17 to 7.4 micrograms per liter and were greater than 1 microgram per liter for most of September. Microcystin was detected periodically in the Big Blue and Delaware Rivers, but concentrations were low (less than or equal to 0.3 microgram per liter). Microcystin was not detected in the Smoky Hill River upstream from the confluence with the Republican River that forms the Kansas River. Temporal patterns in total microcystin concentration, generally, matched patterns in cyanobacterial abundance; however, microcystin was detected for several weeks in October when cyanobacteria were no longer present. Based on concentration and streamflow in the Republican River, total microcystin loads from Milford Lake ranged from 0.1 to 30 kilograms per day on sampled days during September and October 2011.

Temporal patterns in total microcystin concentrations at Kansas River main-stem sites generally matched patterns in the Republican River, with the highest concentrations occurring immediately following the onset of releases from Milford Lake. Microcystin concentrations exceeded 1 microgram per liter at Kansas River main-stem sites upstream from Topeka from September 2 through September 12, 2011, and was detected at all main-stem sites through October 5, 2011. Patterns in microcystin occurrence and concentration at Kansas River tributaries and main-stem sites indicate that Milford Lake was the source of microcystin in the Kansas River during the study period.

Microcystin was not detected in five finished drinkingwater samples collected on September 8 and September 20, 2011, at drinking-water treatment facilities that use the Kansas River as a source-water supply. Finished drinkingwater samples collected as part of this study were frozen as soon as possible after collection, but no chemicals were added to quench the effects of chlorine and the potential effect on ELISA results are unknown. More research on the analysis of cyanotoxins in finished drinking-water samples is required, but available data indicate that drinking-water samples should be processed and analyzed differently than surface-water samples.

Geosmin and MIB were detected in all tributaries located immediately downstream from reservoirs, but not in the Smoky Hill River. The highest total geosmin concentrations occurred in the Republican River, and exceeded the human detection threshold (5 to 10 nanograms per liter) until midOctober 2011. Total geosmin concentrations in the Delaware River exceeded the human detection threshold in late October. MIB was most common in the Big Blue and Delaware Rivers, and total concentrations periodically exceeded the human detection threshold in September 2011. Spatial patterns in geosmin and MIB concentrations at Kansas River main-stem sites were more complex than spatial patterns in microcystin concentration, possibly because multiple tributaries contributed taste-and-odor compounds to the Kansas River. In general, taste-and-odor compounds were detected at most Kansas River main-stem sites until mid-October 2011.

Microcystin and taste-and-odor compounds co-occurred in 56 percent of samples collected from Kansas River tributary and main-stem sites during September and October, 2011, indicating co-occurrence was common. Despite frequent cooccurrence, the spatial and temporal patterns in microcystin, geosmin, and MIB were unique for individual compounds and did not necessarily match patterns in cyanobacterial abundance. Use of a single compound or cyanobacterial abundance cannot necessarily be used as an indicator of the presence or concentration of other compounds. 
Fate and transport of cyanobacteria and associated toxins and taste-and-odor compounds in the Kansas River were described by comparing measured concentrations of cyanobacteria, microcystin, and taste-and-odor compounds at Kansas River main-stem sites to expected concentrations if dilution was the only factor influencing the fate and transport. Measured concentrations of cyanobacteria and associated compounds were substantially higher than expected concentrations at some sites and substantially lower at others, though spatial and temporal patterns were unique for individual compounds. Dissolved microcystin concentrations from a subset of samples indicate particulate and dissolved-phase transport mechanisms likely were important in the Kansas River. Studies designed to specifically evaluate the differences between particulate and dissolved-phase transport of cyanobacterial toxins and taste-and-odor compounds are needed to fully characterize the fate and transport of these compounds during reservoir releases.

Data were not collected in such a way to determine whether differences between measured and expected concentrations were statistically significant; however, results indicate that simple dilution models were not sufficient to describe the downstream transport of cyanobacteria and associated compounds in the Kansas River. The environmental fate and downstream transport of cyanobacterial toxins and taste-andodor compounds within natural conditions has not been well studied. There likely are several factors that affect the downstream transport of cyanobacteria and associated compounds, including losses to and gains from groundwater, the potential for cyanobacterial growth and production of cyanotoxins and taste-and-odor compounds, differential transport of particulate and dissolved phases, and potential for sediment sorption and desorption, photolysis, and biodegradation.

\section{References Cited}

Allan, J.D., 1995, Stream ecology-Structure and function of running waters: Boston, Mass., Kluwer Academic Publishers, 388 p.

Arar, E.J., and Collins, G.B., 1997, U.S. Environmental Protection Agency Method 445.0, In vitro determination of chlorophyll-a and pheophytin-a in marine and freshwater algae by fluorescence, Revision 1.2: Office of Research and Development, $22 \mathrm{p}$.

Baker, A.L., and Baker, K.K., 1981, Seasonal succession of the phytoplankton in the upper Mississippi River: Hydrobiologia, v. 83, p. 295-301.

Bowling, L.C., and Baker, P.D., 1996, Major cyanobacterial bloom in the Barwon-Darling River, Australia, in 1991, and underlying limnological conditions: Marine and Freshwater Research, v. 47, p. 643-657.
Carmichael, W.W., 1997, The cyanotoxins: Advances in Botanical Research, v. 27, p. 211-256.

Carmichael, W.W., and Gorham, P.R., 1981, The mosaic nature of toxic blooms of cyanobacteria, in Carmichael, W.W., ed., The water environment — algal toxins and health: New York, Plenum Press, p. 161-173, 491 p.

Carney, E., 2012, Kansas River Algae Information Exchange Meeting-Stream and River Trophic State and Phytoplankton in Kansas: accessed June 6, 2012, at http://www.kdheks. gov/algae-illness/algae_workshop.htm.

Chen, W., Song, L., Peng, L., Wan, N., Zhang, X., and Gan, N., 2008, Reduction of microcystin concentrations in large and shallow lakes - water and sediment-interface contributions: Water Research, v. 42, p. 763-773.

Chiswell, R.K., Shaw, G.R., Eaglesham, G.K., Smith, M.J., Norris, R.L., Seawright, A.A., and Moore, M.R., 1999, Stability of cylindrospermopsin, the toxin from the cyanobacterium, Cylindrospermopsis raciborskii-effect of $\mathrm{pH}$, temperature, and sunlight on decomposition: Environmental Toxicology, v. 14, p. 155-161.

Chorus, I., and Bartram, J., 1999, Toxic cyanobacteria in water-A Guide to public health significance, monitoring and management: World Health Organization, E \& FN Spon, Chapman \& Hall, London, 416 p. (Also available online at http://www.who.int/water_sanitation_health/ resourcesquality/toxicyanbact/en/index.html).

Christofferson, K., 1996, Ecological implications of cyanobacterial toxins in aquatic food webs: Phycologia, v. 35, p. $42-50$.

Cross, F., and deNoyelles, J.F., 1982, Report on the impacts of commercial dredging on the fishery of the lower Kansas River: U.S. Army Corps of Engineers, Kansas City District, Report DACW 41-79-C-0075, 283 p.

Dell'Aversano, C., Eaglesham, G.K., and Quilliam, M.A., 2004, Analysis of cyanobacterial toxins by hydrophilic interaction liquid chromatography-mass spectrometry: Journal of Chromatography A, v. 1028, p. 155-164.

Falconer, I.R., 1993, Mechanism of toxicity of cyclic peptide toxins from blue-green algae, in Falconer, I.R., ed., Algal toxins in seafood and drinking water: London, Academic Press, p.177-186, 224 p.

Friday, C., and Carmichael, W.W., 2001, Simultaneous analyses of cylindrospermopsin and anatoxin-a in water samples using LC/MS: Proceedings of the 5th International Conference on Toxic Cyanobacteria (ICTC), July 15-19,2001, Noosa, Queensland, Australia.

Froscio, S., Lau, M., Bright, R., and Humpage, A.R., 2010, Methods for measuring toxins in finished water: American Water Works Association Research Foundation, 92 p. 
Fry, J., Xian, G., Jin, S., Dewitz, J., Homer, C., Yang, L., Barnes, C., Herold, N., and Wickham, J., 2011, Completion of the 2006 national land cover database for the conterminous United States: Photogrammetric Engineering \& Remote Sensing, v. 77, p. 858-864.

Graham, J.L., 2006, Harmful algal blooms: U. S. Geological Survey Fact Sheet 2006-3147, 2 p.

Graham, J.L., Loftin, K.A., Ziegler, A.C., and Meyer, M.T., 2008, Cyanobacteria in lakes and reservoirs: toxin and tasteand-odor sampling guidelines (ver. 1.0): U.S. Geological Survey Techniques of Water-Resources Investigations, book 9, chap. A7, section 7.5, September, accessed April 2012 at http://pubs.water.usgs.gov/twri9A/.

Graham, J.L., Loftin, K.A., and Kamman, N., 2009, Monitoring recreational freshwaters: LakeLine, v. 29, p. 16-22.

Graham, J.L., Loftin, K.A., Meyer, M.T., and Ziegler, A.C., 2010, Cyanotoxin mixtures and taste-and-odor compounds in cyanobacterial blooms from the midwestern United States: Environmental Science and Technology, v. 44, p. 7,361-7,368.

Hambrook Berkman, J.A., and Canova, M.G., 2007, Algal biomass indicators (ver. 1.0): U.S. Geological Survey Techniques of Water-Resources Investigations, book 9 chap. A7, section 7.4, accessed April 2012 at http://pubs.water.usgs. gov/twri9A/.

Helgesen, J.O., 1996, Surface-water-quality assessment of the lower Kansas River Basin, Kansas and Nebraska-results of investigations, 1987-90: U.S. Geological Survey, Open-File Report 94-365, 129 p.

Helsel, D.R., and Hirsch, R.M., 2002, Statistical methods in water resources - hydrologic analysis and interpretation: Techniques of Water-Resources Investigations of the U.S. Geological Survey, chap. A3, book 4, 510 p.

Hem, J.D., 1985, Study and interpretation of the chemical characteristics of natural water: U.S. Geological Survey Water-Supply Paper 2254, 263 p.

Heresztyn, T., and Nicholson, B.C., 1997, Nodularian concentrations in Lakes Alexandrina and Albert, South Australia, during a bloom of the cyanobacterium (blue-green alga) Nodularia spumigena and degradation of the toxin: Environmental Toxicology and Water Quality, v. 12, p. 273-282.

Hirsch, R.M., 1979, An evaluation of some record reconstruction techniques: Water Resources Research, v. 15, p. $1,781-1,790$.

Hudnell, H.K., ed., 2008, Cyanobacterial harmful algal blooms - State of the Science and Research Needs: Advances in Experimental Medicine and Biology, v. 619, $950 \mathrm{p}$.
Humphries, S.E., and Lyne, V.D., 1998, Cyanophyte bloomsthe role of cell buoyancy: Limnology and Oceanography, v. 33, p. 79-91.

Jones, G.J., and Orr, P.T., 1994, Release and degradation of microcystin following algicide treatment of a Microcystis aeruginosa bloom in a recreational lake, as determined by HPLC and protein phosphatase inhibition assay: Water Research, v. 28, p. 871-876.

Jordan, P.R., 1995, Surface-water-quality assessment of the lower Kansas River Basin, Kansas and Nebraska: suspended-sediment conditions, May 1987 through April 1990, and trends, 1963 through April 1990: U.S. Geological Survey Water-Resources Investigations Report 94-4187, 36 p.

Jordan, P.R., and Stamer, J.K., 1995, Surface-water-quality assessment of the lower Kansas River Basin, Kansas and Nebraska, analysis of data through 1986: U.S. Geological Survey Water-Supply Paper 2352-B, 161 p.

Juracek, K.E., 2011, Suspended-sediment loads, reservoir sediment trap efficiency, and upstream and downstream channel stability for Kanopolis and Tuttle Creek Lakes, Kansas 2008-10: U.S. Geological Survey Scientific Investigations Report 2011-5187, 35 p.

Kann, J., Bowater, L., and Corum, S., 2010, Middle Klamath River toxic cyanobacteria trends, 2009: Aquatic Ecosystem Sciences LLC Technical Memorandum, 34 p., accessed April 2012, at http://www.klamathwaterquality.com/ documents.html.

Kansas Department of Health and Environment, 2010, BlueGreen Algae in Kansas - Kansas Department of Health and Environment Agency Response Plan: accessed September 16, 2011, at http://www.kdheks.gov/algae-illness/download/ $H A B \_$policy.pdf.

Kansas Department of Health and Environment, 2011, Kansas-Lower Republican Basin total maximum daily load: accessed April 2012, at http://www.kdheks.gov/tmdl/krtmdl. htm.

Kansas Department of Health and Environment, 2012, Guidelines for addressing harmful algal blooms in Kansas recreational waters: accessed June 6, 2012, at http://www.kdheks. gov/algae-illness/download/HAB_policy.pdf.

Kansas Riverkeeper, 2012, Kansas River Inventory: accessed June 18, 2012, at http://www.kansasriver.org/.

Kato, H., Imanishi, S.Y., Tsuji, K., and Harada, K.-I., 2007, Microbial degradation of cyanobacterial cyclic peptides: Water Research, v. 41, p. 1,754-1,762.

Knowlton, M.F., 1984, Flow-through microcuvette for fluorometric determination of chlorophyll: Water Resources Bulletin, v. 20, p. 1,198-1,205. 
Kotak, B.G., Lam, A.K.-Y., Prepas, E.E., and Hrudey, S.E., 2000 , Role of physical and chemical variables in regulating microcystin-LR concentration in phytoplankton of eutrophic lakes: Canadian Journal of Fisheries and Aquatic Sciences, v. 57 , p. $1,584-1,593$.

Krogmann, D.W., Buttala, R., and Sprinkle, J., 1986, Blooms of cyanobacteria in the Potamac River: Plant Physiology, v. 80 , p. $667-671$.

Lanaras, T., Tsitsamis, S., Chlichlia, C., and Cook, C.M., 1989, Toxic cyanobacteria in Greek freshwaters: Journal of Applied Phycology, v. 1, p. 67-73.

Lane, S.L., Flanagan, Sarah, and Wilde, F.D., 2003, Selection of equipment for water sampling (ver. 2.0): U.S. Geological Survey Techniques of Water-Resources Investigations, book 9, chap. A2, accessed April 2012, at http://pubs.water. usgs.gov/twri9A2\%.

Lehman, P.W., Boyer, G., Hall, C., Waller, S., and Gehrts, K., 2005, Distribution and toxicity of a new colonial Microcystis aeruginosa bloom in the San Francisco Bay Estuary, California: Hydrobiologia, v. 541, p. 87-99.

Loftin, K.A., Meyer, M.T., Rubio, F., Kamp, L., Humphries, E., and Whereat, E., 2008, Comparison of two cell lysis procedures for recovery of microcystins in water samples from Silver Lake in Dover, Delaware, with microcystin producing cyanobacterial accumulations: U.S. Geological Survey Open-File Report 2008-1341, 9 p.

Lund, J.W.G., Kipling, C., and LeCren, E.D., 1958, The inverted microscope method of estimated algal numbers and the statistical basis of estimates by counting: Hydrobiologia, v. 11, p. $143-170$.

McNabb, C.D., 1960, Enumeration of freshwater phytoplankton concentrated on the membrane filter: Limnology and Oceanography, v. 5, p. 57-61.

Miller, M.A., Kudela, R.M., Mekebri, A., Crane, D.B., Oates, S.C., Tinker, M.T., Staedler, M., Miller, W.A., Toy-Choutka, S., Dominik, C., Hardin, D., Langlois, G., Murray, M., Ward, K., and Jessup, D.A., 2010, Evidence for a novel marine harmful algal bloom: cyanotoxin (microcystin) transfer from land to sea otters: Public Library of Science ONE, v. 5, e12576.

Oliveira, A.C., Magalhães, V.F., Soares, R.M., and Azevedo, S.M.F.O., 2005, Influence of drinking water composition on quantitation and biological activity of dissolved microcystin (cyanotoxin): Environmental Toxicology, v. 20, p. 126-130.

Paerl, H.W., and Bowles, N.D., 1987, Dilution bioassays: their application to assessments of nutrient limitation in hypereutrophic lakes: Hydrobiologia, v. 146, p. 265-273.
Perry, C.A., 1994, Effects of reservoirs on flood discharges in Kansas and the Missouri River Basins, 1993: U.S. Geological Survey Circular 1120-E, 20 p.

Pope, L.M., 1994, Surface-water quality assessment of the lower Kansas River Basin, Kansas and Nebraska-dissolved oxygen and Escherichia coli bacteria in streams during low flow, July 1988 through July 1989: U.S. Geological Survey Water-Resources Investigations Report 94-4077, 102 p.

Pope, L.M., and Putnam, J.E., 1997, Effects of urbanization on water quality in the Kansas River, Shunganunga Creek Basin, and Soldier Creek, Topeka, Kansas, October 1993 through September 1995: U.S. Geological Survey WaterResources Investigations Report 97-4045, 84 p.

Rapala, J., Erkomaa, K., Kukkonen, J., Sivonen, K., and Lahti, K., 2002, Detection of microcystins with protein phosphatase inhibition assay, high-performance liquid chromatography-UV detection and enzyme-linked immunosorbent assays-comparison of methods: Analytica Chimica Acta, v. 466, p. $213-231$.

Rasmussen, P.P., and Ziegler, A.C., 2003, Comparison and continuous estimates of fecal coliform and Escherichia coli bacteria in selected Kansas streams, May 1999 through April 2002: U.S. Geological Survey Water-Resources Investigations Report 03-4056, $80 \mathrm{p}$.

Rasmussen, P.P., and Christensen, V.G., 2005, Hydrologic and water-quality conditions in the Kansas River, Northeast Kansas, November 2001-August 2001, and simulation of ammonia assimilative capacity and bacteria transport during low flow: U.S. Geological Survey Scientific Investgations Report 2005-5188, $111 \mathrm{p}$.

Rasmussen, T.J., Ziegler, A.C., and Rasmussen, P.P., 2005, Estimation of constituent concentrations, densities, loads, and yields in lower Kansas River, northeast Kansas, using regression models and continuous water-quality monitoring, January 2000 through December 2003: U.S. Geological Survey Scientific Investigations Report 2005-5165, 117 p.

Reynolds, C.S., 1984, The ecology of freshwater phytoplankton: Cambridge, Cambridge University Press, 384 p.

Reynolds, C.S., 1987, Cyanobacterial water blooms: Advances in Botanical Research, v. 13, p. 67-143.

Reynolds, C.S., and Walsby, A.E., 1975, Water-blooms: Biological Reviews, v. 50, p. 437-481.

Sartory, D.P., and Grobbelar, J.U., 1986, Extraction of chlorophyll-a from freshwater phytoplankton for spectrophotometric analysis: Hydrobiolgia, v. 114, p. 117-187.

Sauer, V.B., and Turnipseed, D.P., 2010, Stage measurement at gaging stations: U.S. Geological Survey Techniques and Methods, book 3, chap. A7, 45 p. (Also available at http:// pubs.usgs.gov/tm/tm3-a7/.) 
Sivonen, K., 1996, Cyanobacteria toxins and toxin production: Phycologia, v. 35, p. 12-24.

Spoof, L., Vesterkist, P., Lindholm, T., and Meriluoto, J., 2003, Screening for cyanobacterial hepatotoxins, microcystins, and nodularin in environmental water samples by reversedphase liquid chromotography-electrospray ionization mass spectrometry: Journal of Chromatography A, v. 1020, p. 105-119.

Taylor, W.D., Losee, R.F., Torobin, M., Izaguirre, G., Sass, D., Khiari, D., and Atasi, K., 2005, Early warning and management of surface water taste-and-odor events: American Water Works Association Research Foundation, 373 p.

Thornton, K.W., 1990, Perspectives on reservoir limnology, in Thornton, K.W., Kimmel, B.L., and Payne, F.E., eds., Reservoir Limnology—Ecological Perspectives: New York, John Wiley \& Sons, Inc., p. 1-13., 246 p.

Todd, D.K., 1964, Groundwater, in Chow, V.T., ed., Handbook of Applied Hydrology: New York, McGraw-Hill Book Company, 1,468 p.

Turnipseed, D.P., and Sauer, V.B., 2010, Discharge measurements at gaging stations: U.S. Geological Survey Techniques and Methods, book 3, chap. A8, 87 p. (Also available at $h t t p: / / p u b s . u s g s . g o v / t m / t m 3-a 8 /$.

U.S. Army Corps of Engineers, Kansas City District, 2011, Annual report of reservoir regulation activities, summary for 2010-2011: Enginnering Division, Hydrologic Engineering Branch, Water Management Section, 79 p., accessed April 2012, at http://www.nwk.usace.army.mil/ WaterManagement/AnnualReportOfReservoirRegulationAc tivities.pdf.

U.S. Army Corps of Engineers, Kansas City District, 2012, Kansas City district lakes: accessed June 18, 2012, at http:// www.nwk.usace.army.mil/lakes/.

U.S. Environmental Protection Agency, 2009, Final third drinking water contaminant candidate list (CCL 3): EPA Office of Water, 8 p., accessed April 2012, at http://www. epa.gov/ogwdw/ccl/pdfs/ccl3_docs/fs_cc3_final.pdf.

U.S. Geological Survey, 2006, Collection of water samples (ver. 2.0): U.S. Geological Survey Techniques of WaterResources Investigations, book 9, chap. A4. (Also available at http://pubs.water.usgs.gov/twri9A4/).

U.S. Geological Survey, variously dated, National field manual for the collection of water-quality data: U.S. Geological Survey Techniques of Water-Resources Investigations, book 9, chaps. A1-A9. (Also available at http://pubs.water. usgs.gov/twri9A). van der Merwe, D., Sebbag, L., Nietfeld, J.C., Aubel, M.T., Foss, A., and Carney, E., 2012, Investigation of a Microcystis aeruginosa cyanobacterial freshwater harmful algal bloom associated with acute microcystin toxicosis in a dog: Journal of Veterinary Diagnostic Investigation, doi: 10.1177/1040638712445768, accessed June 6, 2012, at http://www.researchgate.net/journal/19434936_Journal_ of_veterinary_diagnostic_investigation_official_publication_of_the_American_Association_of_Veterinary_Laboratory_Diagnosticians_Inc.

Wagner, R.J., Boulger, R.W., Jr., Oblinger, C.J., and Smith, B.A., 2006, Guidelines and standard procedures for continuous water-quality monitors-Station operation, record computation, and data reporting: U.S. Geological Survey Techniques and Methods 1-D3, 51 p. +8 attachments, accessed April 2012, at http://pubs.water.usgs.gov/tm1d3.

Wehr, J.D., and Sheath, R.G., eds., 2003, Freshwater algae of North America-Ecology and classification: San Diego, California, Academic Press, 918 p.

Westerhoff, P., Rodriguez-Hernandez, M., Baker, L., and Sommerfeld, M., 2005, Seasonal occurrence and degradation of 2-methylisoborneol in water supply reservoirs: Water Research, v. 39, p. 4,899-4,912.

Westrick, J.A., Szlag, D.C., Southwell, B.J., and Sinclair, J.L., 2010, A review of cyanobacteria and cyanotoxins removal/ inactivation in drinking water treatment: Analytical and Bioanalytical Chemistry, v. 397, p. 1,705-1,714.

Wörmer, L., Huerta-Fontela, M., Cirés, S., Carrasco, D., and Quesada, A., 2010, Natural photodegradation of the cyanobacterial toxins microcystin and cylindrospermopsin: Environmental Science and Technology, v. 44, p. 3,002-3,007.

Wu, X., Xiao, B., Li, R., Wang, C., Huang, J., and Wang, Z., 2011, Mechanisms and factors affecting sorption of microcystins onto natural sediments: Environmental Science and Technology, v. 45, p. 2,641-2,647.

Zaitlin, B., and Watson, S.B., 2006, Actinomycetes in relation to taste and odour in drinking water-Myths, tenets, and truths: Water Research, v. 40, p. 1,741-1,753.

Zaitlin, B., Watson, S.B., Ridal, J., Satchwill, T., and Parkinson, D., 2003, Actinomycetes in Lake Ontario-Habitats and geosmin and MIB production: Journal of the American Water Works Association, v. 95, p. 113-118.

Zimmerman, L.R., Ziegler, A.C., and Thurman, E.M., 2002, Method of analysis and quality-assurance practices by U.S. Geological Survey Organic Geochemistry Research Group-Determination of geosmin and methylisoborneol in water using solid-phase microextraction and gas chromatograhphy/mass spectrometery: U.S. Geological Survey Open-File Report 02-337, 12 p. 

Appendix 1. U.S. Geological Survey streamflow-gaging stations used to describe streamflow conditions in the Kansas River during August through October 2011.

[R, River; KS, Kansas; C, Creek; nr, near; St, street]

\begin{tabular}{lccc}
\hline \multicolumn{1}{c}{ Site name } & $\begin{array}{c}\text { U.S. Geological Survey } \\
\text { identification number }\end{array}$ & $\begin{array}{c}\text { Drainage area } \\
\text { (miles }^{2} \text { ) }\end{array}$ & Period of record \\
\hline Smoky Hill R at Enterprise, KS & Kansas River tributary sites & & \\
Chapman C nr Chapman, KS & 06877600 & 19,260 & October 1934-October 2011. \\
Republican R at Junction City, KS & 06878000 & 300 & December 1953-October 2011. \\
Big Blue R nr Manhattan, KS & 06857100 & 24,900 & October 1963-October 2011. \\
Vermillion C nr Wamego, KS & 06887000 & 9,640 & October 1950-October 2011. \\
Mill C nr Paxico, KS & 06888000 & 243 & April 1936-October 2011. \\
Soldier C nr Topeka, KS & 06888500 & 318 & December 1953-October 2011. \\
Shunganunga C at Topeka, KS & 06889500 & 290 & May 1929-October 2011. \\
Delaware R at Perry, KS & 06889630 & 34 & October 2010-October 2011. \\
Wakarusa R nr Lawrence, KS & 06890900 & 1,141 & March 1969-October 2011. \\
Stranger C nr Tonganoxie, KS & 06891500 & 425 & April 1929-October 2011. \\
Kill C at 95th St nr Desoto, KS & 06892000 & 406 & April 1929-October 2011. \\
Cedar C nr Desoto, KS & 06892360 & 53 & March 2003-October 2011. \\
Mill C at Johnson Drive, Shawnee, KS & 06892495 & 58 & October 2002-October 2011. \\
\hline & 06892513 & 58 & October 2002-October 2011. \\
\hline Kansas R at Fort Riley, KS & Kansas River main-stem sites & & \\
Kansas R at Wamego, KS & 06879100 & 44,870 & December 1963-October 2011. \\
Kansas R nr Belvue, KS & 06887500 & 55,280 & January 1919-October 2011. \\
Kansas R at Topeka, KS & 06888350 & 55,870 & October 1982-October 2011. \\
Kansas R at Lecompton, KS & 06889000 & 56,720 & June 1917-October 2011. \\
Kansas R at Desoto, KS & 06891000 & 58,460 & March 1936-October 2011. \\
\hline
\end{tabular}


Appendix 2. Discrete water-quality sampling results from samples collected from Kansas River tributary and main-stem sites during September and October 2011.

[nr, near; KS, Kansas; $\mu \mathrm{S} / \mathrm{cm}$, microsiemens per centimeter at 25 degrees Celsius; --, sample not collected; ${ }^{\circ} \mathrm{C}$, degrees Celsius; FNU, formazin nephelometric units; mg/L, milligrams per liter; \%, percent; $\mu \mathrm{g} / \mathrm{L}$, micrograms per liter; >, greater than; nm, analyte not measured but sample archived; <, less than; ng/L, nanograms per liter; $\mathrm{ft}^{3} / \mathrm{s}$, cubic feet per second; se, sonde measurement error; R, River; Pl, Plaza]

\begin{tabular}{|c|c|c|c|c|c|c|c|c|c|c|c|}
\hline Water-quality property & $09 / 02 / 11$ & 09/08/11 & $09 / 12 / 11$ & $09 / 20 / 11$ & $09 / 26 / 11$ & $10 / 03 / 11$ & $10 / 05 / 11$ & 10/11/11 & 10/17/11 & $10 / 24 / 11$ & $10 / 31 / 11$ \\
\hline \multicolumn{12}{|c|}{ Milford Reservoir sampling sites } \\
\hline \multicolumn{12}{|c|}{ Milford Lake nr Junction City, KS (06857050) } \\
\hline $\begin{array}{l}\text { Specific conductance } \\
(\mu \mathrm{S} / \mathrm{cm})\end{array}$ & 549 & 551 & 553 & 562 & 567 & 574 & -- & -- & -- & -- & -- \\
\hline $\mathrm{pH}$ & 9.6 & 8.6 & 8.8 & 8.5 & 8.7 & 8.6 & -- & -- & -- & -- & -- \\
\hline Water temperature $\left({ }^{\circ} \mathrm{C}\right)$ & 27.9 & 24.0 & 22.5 & 21.6 & 20.8 & 19.9 & -- & -- & -- & -- & -- \\
\hline $\begin{array}{l}\text { Dissolved oxygen satura- } \\
\text { tion }(\%)\end{array}$ & 78.0 & 69.6 & 106.0 & 79.8 & 93.5 & 72.0 & -- & -- & -- & -- & -- \\
\hline $\begin{array}{l}\text { Fluorescence }(\mu \mathrm{g} / \mathrm{L} \text {, as } \\
\text { chlorophyll) }\end{array}$ & 76 & 1.9 & 19 & 5.1 & 1.9 & 4.6 & -- & -- & -- & -- & -- \\
\hline Chlorophyll $(\mu \mathrm{g} / \mathrm{L})$ & -- & -- & -- & 1,000 & 3.3 & 5.8 & -- & -- & -- & -- & -- \\
\hline Total anatoxin-a $(\mu \mathrm{g} / \mathrm{L})$ & $\mathrm{nm}$ & $\mathrm{nm}$ & -- & $\mathrm{nm}$ & $\mathrm{nm}$ & $\mathrm{nm}$ & -- & -- & -- & -- & -- \\
\hline $\begin{array}{l}\text { Total cylindrospermopsin } \\
\qquad(\mu \mathrm{g} / \mathrm{L})\end{array}$ & $<0.05$ & $\mathrm{~nm}$ & -- & $\mathrm{nm}$ & $\mathrm{nm}$ & $\mathrm{nm}$ & -- & -- & -- & -- & -- \\
\hline Total saxitoxin $(\mu \mathrm{g} / \mathrm{L})$ & $<0.02$ & $\mathrm{~nm}$ & -- & $\mathrm{nm}$ & $\mathrm{nm}$ & $\mathrm{nm}$ & -- & -- & -- & -- & -- \\
\hline Total geosmin $(\mathrm{ng} / \mathrm{L})$ & -- & 170 & $\mathrm{~nm}$ & -- & -- & $\mathrm{nm}$ & -- & -- & -- & -- & -- \\
\hline $\begin{array}{l}\text { Total 2-methylisoborneol } \\
\text { (ng/L) }\end{array}$ & -- & $<2.0$ & $\mathrm{~nm}$ & -- & -- & $\mathrm{nm}$ & -- & -- & -- & -- & -- \\
\hline \multicolumn{12}{|c|}{ Milford Lake outlet, KS (390433096534600) } \\
\hline $\begin{array}{l}\text { Specific conductance } \\
(\mu \mathrm{S} / \mathrm{cm})\end{array}$ & 545 & se & 556 & 561 & 569 & 573 & -- & -- & -- & -- & -- \\
\hline $\mathrm{pH}$ & 8.4 & se & 8.7 & 8.5 & 8.5 & 8.4 & -- & -- & -- & -- & -- \\
\hline Chlorophyll $(\mu \mathrm{g} / \mathrm{L})$ & 8.9 & 7.1 & 9.2 & 2.0 & 2.2 & 2.1 & -- & -- & -- & -- & -- \\
\hline Total microcystin $(\mu \mathrm{g} / \mathrm{L})$ & 6.2 & 4.4 & 3.9 & 1.1 & 0.4 & 0.3 & -- & -- & -- & -- & -- \\
\hline $\begin{array}{l}\text { Dissolved microcystin } \\
\quad(\mu \mathrm{g} / \mathrm{L})\end{array}$ & -- & -- & -- & 0.2 & $\mathrm{~nm}$ & $\mathrm{~nm}$ & -- & -- & -- & -- & -- \\
\hline Total anatoxin-a $(\mu \mathrm{g} / \mathrm{L})$ & $<0.1$ & $\mathrm{~nm}$ & $\mathrm{~nm}$ & $\mathrm{~nm}$ & $\mathrm{~nm}$ & $\mathrm{~nm}$ & -- & -- & -- & -- & -- \\
\hline $\begin{array}{l}\text { Total cylindrospermopsin } \\
\qquad(\mu \mathrm{g} / \mathrm{L})\end{array}$ & $<0.05$ & $\mathrm{~nm}$ & $\mathrm{~nm}$ & $\mathrm{~nm}$ & $\mathrm{~nm}$ & $\mathrm{~nm}$ & -- & -- & -- & -- & -- \\
\hline Total saxitoxin $(\mu \mathrm{g} / \mathrm{L})$ & $<0.02$ & $\mathrm{~nm}$ & $\mathrm{~nm}$ & $\mathrm{~nm}$ & $\mathrm{~nm}$ & $\mathrm{~nm}$ & -- & -- & -- & -- & -- \\
\hline Total geosmin (ng/L) & 7.9 & 8.6 & $\mathrm{~nm}$ & $\mathrm{~nm}$ & -- & $\mathrm{nm}$ & -- & -- & -- & -- & -- \\
\hline $\begin{array}{l}\text { Total 2-methylisoborneol } \\
\text { (ng/L) }\end{array}$ & $<2.0$ & $<2.0$ & $\mathrm{~nm}$ & $\mathrm{~nm}$ & -- & $\mathrm{nm}$ & -- & -- & -- & -- & -- \\
\hline
\end{tabular}


Appendix 2. Discrete water-quality sampling results from samples collected from Kansas River tributary and main-stem sites during September and October 2011. - Continued

[nr, near; KS, Kansas; $\mu \mathrm{S} / \mathrm{cm}$, microsiemens per centimeter at 25 degrees Celsius; --, sample not collected; ${ }^{\circ} \mathrm{C}$, degrees Celsius; FNU, formazin nephelometric units; $\mathrm{mg} / \mathrm{L}$, milligrams per liter; \%, percent; $\mu \mathrm{g} / \mathrm{L}$, micrograms per liter; >, greater than; nm, analyte not measured but sample archived; <, less than; ng/L, nanograms per liter; $\mathrm{ft}^{3} / \mathrm{s}$, cubic feet per second; se, sonde measurement error; R, River; Pl, Plaza]

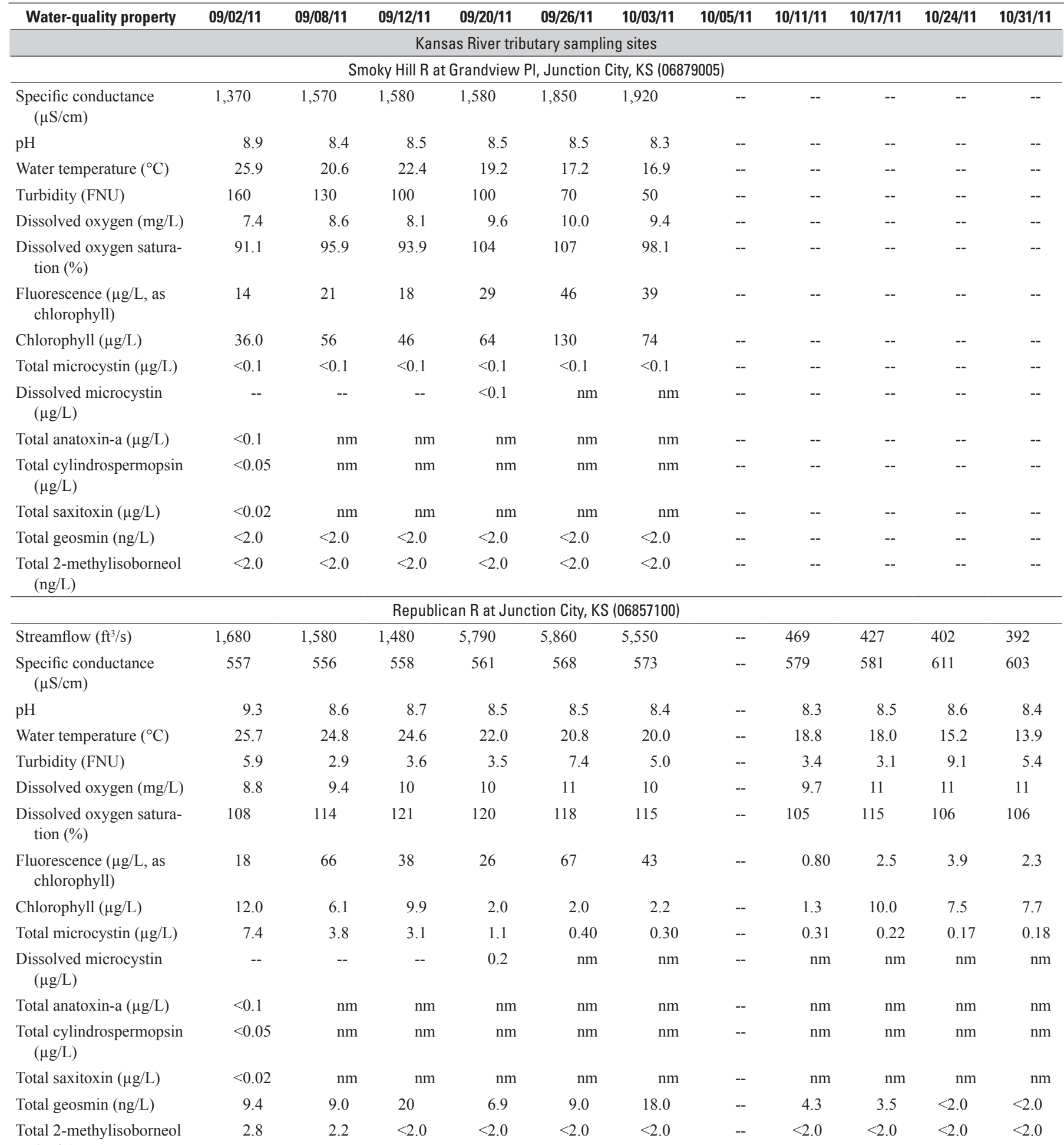
(ng/L) 
Appendix 2. Discrete water-quality sampling results from samples collected from Kansas River tributary and main-stem sites during September and October 2011.-Continued

[nr, near; KS, Kansas; $\mu \mathrm{S} / \mathrm{cm}$, microsiemens per centimeter at 25 degrees Celsius; --, sample not collected; ${ }^{\circ} \mathrm{C}$, degrees Celsius; FNU, formazin nephelometric units; mg/L, milligrams per liter; \%, percent; $\mu \mathrm{g} / \mathrm{L}$, micrograms per liter; >, greater than; nm, analyte not measured but sample archived; <, less than; ng/L, nanograms per liter; $\mathrm{ft}^{3} / \mathrm{s}$, cubic feet per second; se, sonde measurement error; R, River; Pl, Plaza]

\begin{tabular}{|c|c|c|c|c|c|c|c|c|c|c|c|}
\hline Water-quality property & $09 / 02 / 11$ & $09 / 08 / 11$ & $09 / 12 / 11$ & $09 / 20 / 11$ & $09 / 26 / 11$ & $10 / 03 / 11$ & $10 / 05 / 11$ & 10/11/11 & $10 / 17 / 11$ & $10 / 24 / 11$ & $10 / 31 / 11$ \\
\hline \multicolumn{12}{|c|}{ Big Blue R nr Manhattan, KS (06887000) } \\
\hline Streamflow $\left(\mathrm{ft}^{3} / \mathrm{s}\right)$ & 1,050 & 1,020 & 1,000 & 5,270 & 7,870 & 3,630 & -- & 310 & 302 & 282 & 298 \\
\hline $\mathrm{pH}$ & 8.7 & 8.3 & 8.3 & 8.3 & 8.4 & 8.4 & -- & 8.4 & 8.3 & 8.6 & 8.4 \\
\hline Water temperature $\left({ }^{\circ} \mathrm{C}\right)$ & 26.2 & 25.0 & 24.6 & 22.4 & 21.1 & 19.9 & -- & 18.7 & 17.2 & 14.8 & 13.3 \\
\hline $\begin{array}{l}\text { Dissolved oxygen satura- } \\
\text { tion }(\%)\end{array}$ & 96.4 & 103.0 & 104.0 & 108.0 & 111.0 & 104.0 & -- & 98.6 & 95.9 & 98.1 & 102.0 \\
\hline $\begin{array}{l}\text { Fluorescence }(\mu \mathrm{g} / \mathrm{L} \text {, as } \\
\text { chlorophyll) }\end{array}$ & 4.2 & 4.2 & 3.2 & 2.7 & 2.9 & 0.40 & -- & 4.4 & 4.4 & 4.7 & 4.8 \\
\hline Chlorophyll $(\mu \mathrm{g} / \mathrm{L})$ & 6.0 & 12 & 7.3 & 4.4 & 3.7 & 5.6 & -- & 5.3 & 16.5 & 9.0 & 17.0 \\
\hline Total anatoxin-a $(\mu \mathrm{g} / \mathrm{L})$ & $<0.1$ & $\mathrm{~nm}$ & $\mathrm{~nm}$ & $\mathrm{~nm}$ & $\mathrm{~nm}$ & $\mathrm{~nm}$ & -- & $\mathrm{nm}$ & $\mathrm{nm}$ & $\mathrm{nm}$ & $\mathrm{nm}$ \\
\hline $\begin{array}{l}\text { Total cylindrospermopsin } \\
\quad(\mu \mathrm{g} / \mathrm{L})\end{array}$ & $<0.05$ & $\mathrm{~nm}$ & $\mathrm{~nm}$ & $\mathrm{~nm}$ & $\mathrm{~nm}$ & $\mathrm{~nm}$ & -- & $\mathrm{nm}$ & $\mathrm{nm}$ & $\mathrm{nm}$ & $\mathrm{nm}$ \\
\hline Total saxitoxin $(\mu \mathrm{g} / \mathrm{L})$ & $<0.02$ & $\mathrm{~nm}$ & $\mathrm{~nm}$ & $\mathrm{~nm}$ & $\mathrm{~nm}$ & $\mathrm{~nm}$ & -- & $\mathrm{nm}$ & $\mathrm{nm}$ & $\mathrm{nm}$ & $\mathrm{nm}$ \\
\hline Total geosmin (ng/L) & $<2.0$ & $<2.0$ & $<2.0$ & $<2.0$ & $<2.0$ & $<2.0$ & -- & 2.1 & 2.5 & $<2.0$ & $<2.0$ \\
\hline $\begin{array}{l}\text { Total 2-methylisoborneol } \\
\text { (ng/L) }\end{array}$ & 3.7 & 4.8 & 3.8 & 7.7 & 4.4 & 3.9 & -- & 4.7 & 2.9 & 3.5 & $<2.0$ \\
\hline \multicolumn{12}{|c|}{ Delaware R at Perry, KS (06890900) } \\
\hline Streamflow $\left(\mathrm{ft}^{3} / \mathrm{s}\right)$ & 166 & 172 & 199 & 1,030 & 1,960 & 107 & -- & 49.9 & 43.3 & 40.6 & 42.5 \\
\hline $\begin{array}{l}\text { Specific conductance } \\
\qquad(\mu \mathrm{S} / \mathrm{cm})\end{array}$ & 319 & 312 & 316 & 310 & 309 & 310 & -- & 324 & 335 & 318 & 341 \\
\hline $\begin{array}{l}\text { Fluorescence }(\mu \mathrm{g} / \mathrm{L} \text {, as } \\
\text { chlorophyll) }\end{array}$ & 4 & 7 & 5 & 2 & 3 & 4 & -- & 11 & & 6 & 4 \\
\hline Chlorophyll ( $\mu \mathrm{g} / \mathrm{L})$ & 9.9 & 20 & 9.7 & 4.0 & 4.3 & 2.8 & -- & 21 & 16 & 9.7 & 11 \\
\hline Total microcystin $(\mu \mathrm{g} / \mathrm{L})$ & 0.13 & 0.30 & $<0.1$ & $<0.1$ & $<0.1$ & 0.1 & -- & $<0.1$ & $<0.1$ & $<0.1$ & $<0.1$ \\
\hline $\begin{array}{l}\text { Dissolved microcystin } \\
\quad(\mu \mathrm{g} / \mathrm{L})\end{array}$ & -- & -- & -- & $<0.1$ & $\mathrm{~nm}$ & $\mathrm{~nm}$ & -- & $\mathrm{nm}$ & $\mathrm{nm}$ & $\mathrm{nm}$ & $\mathrm{nm}$ \\
\hline Total anatoxin-a $(\mu \mathrm{g} / \mathrm{L})$ & $<0.1$ & $\mathrm{~nm}$ & $\mathrm{~nm}$ & $\mathrm{~nm}$ & $\mathrm{~nm}$ & $\mathrm{~nm}$ & -- & $\mathrm{nm}$ & $\mathrm{nm}$ & $\mathrm{nm}$ & $\mathrm{nm}$ \\
\hline $\begin{array}{l}\text { Total cylindrospermopsin } \\
\qquad(\mu \mathrm{g} / \mathrm{L})\end{array}$ & $<0.05$ & $\mathrm{~nm}$ & $\mathrm{~nm}$ & $\mathrm{~nm}$ & $\mathrm{~nm}$ & $\mathrm{~nm}$ & -- & $\mathrm{nm}$ & $\mathrm{nm}$ & $\mathrm{nm}$ & $\mathrm{nm}$ \\
\hline Total saxitoxin $(\mu \mathrm{g} / \mathrm{L})$ & $<0.02$ & $\mathrm{~nm}$ & $\mathrm{~nm}$ & $\mathrm{~nm}$ & $\mathrm{~nm}$ & $\mathrm{~nm}$ & -- & $\mathrm{nm}$ & $\mathrm{nm}$ & $\mathrm{nm}$ & $\mathrm{nm}$ \\
\hline Total geosmin (ng/L) & $<2.0$ & 7.7 & $<2.0$ & 2.5 & 4.8 & 3.9 & -- & 7.8 & 5.4 & 11 & 4.5 \\
\hline Total 2-methylisoborneol & 12 & 29 & 28 & 14 & 16 & 3.3 & -- & 2.4 & $<2.0$ & $<2.0$ & $<2.0$ \\
\hline
\end{tabular}
(ng/L) 
Appendix 2. Discrete water-quality sampling results from samples collected from Kansas River tributary and main-stem sites during September and October 2011. - Continued

[nr, near; KS, Kansas; $\mu \mathrm{S} / \mathrm{cm}$, microsiemens per centimeter at 25 degrees Celsius; --, sample not collected; ${ }^{\circ} \mathrm{C}$, degrees Celsius; FNU, formazin nephelometric units; $\mathrm{mg} / \mathrm{L}$, milligrams per liter; \%, percent; $\mu \mathrm{g} / \mathrm{L}$, micrograms per liter; >, greater than; nm, analyte not measured but sample archived; <, less than; ng/L, nanograms per liter; $\mathrm{ft}^{3} / \mathrm{s}$, cubic feet per second; se, sonde measurement error; R, River; Pl, Plaza]

\begin{tabular}{|c|c|c|c|c|c|c|c|c|c|c|c|}
\hline Water-quality property & $09 / 02 / 11$ & $09 / 08 / 11$ & $09 / 12 / 11$ & $09 / 20 / 11$ & $09 / 26 / 11$ & $10 / 03 / 11$ & $10 / 05 / 11$ & $10 / 11 / 11$ & $10 / 17 / 11$ & $10 / 24 / 11$ & $10 / 31 / 11$ \\
\hline \multicolumn{12}{|c|}{ Wakarusa R nr Lawrence, KS (06891500) } \\
\hline Streamflow $\left(\mathrm{ft}^{3} / \mathrm{s}\right)$ & 24.9 & 31.7 & 25.6 & 26.3 & 24.9 & 2.46 & -- & -- & -- & -- & -- \\
\hline $\begin{array}{l}\text { Specific conductance } \\
(\mu \mathrm{S} / \mathrm{cm})\end{array}$ & 332 & 321 & 306 & 343 & 338 & 358 & -- & -- & -- & -- & -- \\
\hline $\mathrm{pH}$ & 8.7 & 8.0 & 7.9 & 8.1 & 8.1 & 8.2 & -- & -- & -- & -- & -- \\
\hline Water temperature $\left({ }^{\circ} \mathrm{C}\right)$ & 27.1 & 21.1 & 25.1 & 19.2 & 15.7 & 14.6 & -- & -- & -- & -- & -- \\
\hline $\begin{array}{l}\text { Dissolved oxygen satura- } \\
\text { tion }(\%)\end{array}$ & 87.9 & 82.3 & 73.3 & 83.7 & 85.9 & 79.1 & -- & -- & -- & -- & -- \\
\hline $\begin{array}{l}\text { Fluorescence }(\mu \mathrm{g} / \mathrm{L} \text {, as } \\
\quad \text { chlorophyll) }\end{array}$ & 6.1 & 2.4 & 2.8 & 0.10 & 2.3 & 2.3 & -- & -- & -- & -- & -- \\
\hline Chlorophyll ( $\mu \mathrm{g} / \mathrm{L})$ & 15 & 8.8 & 6.7 & 5.5 & 4.2 & 3.0 & -- & -- & -- & -- & -- \\
\hline Total anatoxin-a $(\mu \mathrm{g} / \mathrm{L})$ & $<0.1$ & $\mathrm{~nm}$ & $\mathrm{~nm}$ & $\mathrm{~nm}$ & $\mathrm{~nm}$ & $\mathrm{~nm}$ & -- & -- & -- & -- & -- \\
\hline $\begin{array}{l}\text { Total cylindrospermopsin } \\
\quad(\mu \mathrm{g} / \mathrm{L})\end{array}$ & $<0.05$ & $\mathrm{~nm}$ & $\mathrm{~nm}$ & $\mathrm{~nm}$ & $\mathrm{~nm}$ & $\mathrm{~nm}$ & -- & -- & -- & -- & -- \\
\hline Total saxitoxin $(\mu \mathrm{g} / \mathrm{L})$ & $<0.02$ & $\mathrm{~nm}$ & $\mathrm{~nm}$ & $\mathrm{~nm}$ & $\mathrm{~nm}$ & $\mathrm{~nm}$ & -- & -- & -- & -- & -- \\
\hline Total geosmin (ng/L) & 4.7 & 4.4 & $\mathrm{~nm}$ & $\mathrm{~nm}$ & -- & $\mathrm{nm}$ & -- & -- & -- & -- & -- \\
\hline $\begin{array}{l}\text { Total 2-methylisoborneol } \\
\text { (ng/L) }\end{array}$ & 4.7 & 4.7 & $\mathrm{~nm}$ & $\mathrm{~nm}$ & -- & $\mathrm{nm}$ & -- & -- & -- & -- & -- \\
\hline \multicolumn{12}{|c|}{ Kansas River main-stem sampling sites } \\
\hline \multicolumn{12}{|c|}{ Kansas R at Fort Riley, KS (06879100) } \\
\hline Streamflow $\left(\mathrm{ft}^{3} / \mathrm{s}\right)$ & 2,480 & 2,290 & 2,230 & 6,560 & 6,540 & 6,420 & -- & -- & -- & -- & -- \\
\hline $\begin{array}{l}\text { Specific conductance } \\
\quad(\mu \mathrm{S} / \mathrm{cm})\end{array}$ & 829 & 862 & 860 & 675 & 677 & 668 & -- & -- & -- & -- & -- \\
\hline $\begin{array}{l}\text { Fluorescence }(\mu \mathrm{g} / \mathrm{L}, \text { as } \\
\quad \text { chlorophyll) }\end{array}$ & 4.0 & 3.1 & 1.8 & 2.5 & 6.9 & 0.40 & -- & -- & -- & -- & -- \\
\hline Chlorophyll ( $\mu \mathrm{g} / \mathrm{L})$ & 29.0 & 20 & 19 & 8.5 & 18.0 & 7.1 & -- & -- & -- & -- & -- \\
\hline Total microcystin $(\mu \mathrm{g} / \mathrm{L})$ & 4.8 & 3.6 & 2.4 & 0.64 & 0.23 & 0.32 & -- & -- & -- & -- & -- \\
\hline $\begin{array}{l}\text { Dissolved microcystin } \\
\quad(\mu \mathrm{g} / \mathrm{L})\end{array}$ & -- & -- & -- & $\mathrm{nm}$ & $\mathrm{nm}$ & $\mathrm{nm}$ & -- & -- & -- & -- & -- \\
\hline Total anatoxin-a $(\mu \mathrm{g} / \mathrm{L})$ & $<0.1$ & $\mathrm{~nm}$ & $\mathrm{~nm}$ & $\mathrm{~nm}$ & $\mathrm{~nm}$ & $\mathrm{~nm}$ & -- & -- & -- & -- & -- \\
\hline $\begin{array}{l}\text { Total cylindrospermopsin } \\
\qquad(\mu \mathrm{g} / \mathrm{L})\end{array}$ & $<0.05$ & $\mathrm{~nm}$ & $\mathrm{~nm}$ & $\mathrm{~nm}$ & $\mathrm{~nm}$ & $\mathrm{~nm}$ & -- & -- & -- & -- & -- \\
\hline Total saxitoxin $(\mu \mathrm{g} / \mathrm{L})$ & $<0.02$ & $\mathrm{~nm}$ & $\mathrm{~nm}$ & $\mathrm{~nm}$ & $\mathrm{~nm}$ & $\mathrm{~nm}$ & -- & -- & -- & -- & -- \\
\hline Total geosmin (ng/L) & 6.1 & 6.7 & $\mathrm{~nm}$ & $\mathrm{~nm}$ & -- & $\mathrm{nm}$ & -- & -- & -- & -- & -- \\
\hline $\begin{array}{l}\text { Total 2-methylisoborneol } \\
\quad(\mathrm{ng} / \mathrm{L})\end{array}$ & $<2.0$ & 4.3 & $\mathrm{~nm}$ & $\mathrm{~nm}$ & -- & $\mathrm{nm}$ & -- & -- & -- & -- & -- \\
\hline
\end{tabular}


Appendix 2. Discrete water-quality sampling results from samples collected from Kansas River tributary and main-stem sites during September and October 2011.-Continued

[nr, near; KS, Kansas; $\mu \mathrm{S} / \mathrm{cm}$, microsiemens per centimeter at 25 degrees Celsius; --, sample not collected; ${ }^{\circ} \mathrm{C}$, degrees Celsius; FNU, formazin nephelometric units; mg/L, milligrams per liter; \%, percent; $\mu \mathrm{g} / \mathrm{L}$, micrograms per liter; >, greater than; nm, analyte not measured but sample archived; <, less than; ng/L, nanograms per liter; $\mathrm{ft}^{3} / \mathrm{s}$, cubic feet per second; se, sonde measurement error; R, River; Pl, Plaza]

\begin{tabular}{|c|c|c|c|c|c|c|c|c|c|c|c|}
\hline Water-quality property & $09 / 02 / 11$ & $09 / 08 / 11$ & $09 / 12 / 11$ & $09 / 20 / 11$ & $09 / 26 / 11$ & $10 / 03 / 11$ & $10 / 05 / 11$ & $10 / 11 / 11$ & 10/17/11 & $10 / 24 / 11$ & $10 / 31 / 11$ \\
\hline \multicolumn{12}{|c|}{ Kansas R at Manhattan, KS (06879820) } \\
\hline $\begin{array}{l}\text { Specific conductance } \\
(\mu \mathrm{S} / \mathrm{cm})\end{array}$ & 816 & 861 & 853 & 677 & 665 & 670 & -- & -- & -- & -- & -- \\
\hline Water temperature $\left({ }^{\circ} \mathrm{C}\right)$ & 26.3 & 22.7 & 23.8 & 21.6 & 19.8 & 19.8 & -- & -- & -- & -- & -- \\
\hline Turbidity (FNU) & 140 & 56 & 42 & 58 & 23 & 22 & -- & -- & -- & -- & -- \\
\hline $\begin{array}{l}\text { Fluorescence }(\mu \mathrm{g} / \mathrm{L} \text {, as } \\
\text { chlorophyll) }\end{array}$ & 8.4 & 9.2 & 8.3 & 5.8 & 9.4 & 11 & -- & -- & -- & -- & -- \\
\hline Chlorophyll $(\mu \mathrm{g} / \mathrm{L})$ & 23 & 21 & 24 & 12 & 24 & 10 & -- & -- & -- & -- & -- \\
\hline Total microcystin $(\mu \mathrm{g} / \mathrm{L})$ & 7.7 & 5.0 & 3.5 & 0.82 & 0.24 & 0.35 & -- & -- & -- & -- & -- \\
\hline $\begin{array}{l}\text { Total cylindrospermopsin } \\
\qquad(\mu \mathrm{g} / \mathrm{L})\end{array}$ & $<0.05$ & $\mathrm{~nm}$ & $\mathrm{~nm}$ & $\mathrm{~nm}$ & $\mathrm{~nm}$ & $\mathrm{~nm}$ & -- & -- & -- & -- & -- \\
\hline Total saxitoxin $(\mu \mathrm{g} / \mathrm{L})$ & $<0.02$ & $\mathrm{~nm}$ & $\mathrm{~nm}$ & $\mathrm{~nm}$ & $\mathrm{~nm}$ & $\mathrm{~nm}$ & -- & -- & -- & -- & -- \\
\hline Total geosmin (ng/L) & 4.5 & 7.9 & $\mathrm{~nm}$ & $\mathrm{~nm}$ & -- & $\mathrm{nm}$ & -- & -- & -- & -- & -- \\
\hline $\begin{array}{l}\text { Total 2-methylisoborneol } \\
\text { (ng/L) }\end{array}$ & $<2.0$ & $<2.0$ & $\mathrm{~nm}$ & $\mathrm{~nm}$ & -- & $\mathrm{nm}$ & -- & -- & -- & -- & -- \\
\hline \multicolumn{12}{|c|}{ Kansas $R$ at Wamego, KS (06887500) } \\
\hline Streamflow $\left(\mathrm{ft}^{3} / \mathrm{s}\right)$ & 3,100 & 3,100 & 3,100 & 11,300 & 14,600 & 10,000 & 7,080 & 1,630 & 1,420 & 1,390 & 1,320 \\
\hline $\begin{array}{l}\text { Specific conductance } \\
\qquad(\mu \mathrm{S} / \mathrm{cm})\end{array}$ & 714 & 744 & 715 & 537 & 494 & 545 & 639 & 948 & 982 & 1,040 & 1,040 \\
\hline $\mathrm{pH}$ & 8.2 & 8.4 & 8.5 & 8.4 & 8.5 & 8.4 & 8.4 & 8.7 & 8.6 & 8.9 & 8.6 \\
\hline Chlorophyll $(\mu \mathrm{g} / \mathrm{L})$ & 33 & 22 & 22 & 8.5 & 8.7 & 11 & 12 & 50 & 110 & 49 & 73 \\
\hline Total microcystin $(\mu \mathrm{g} / \mathrm{L})$ & 2.2 & 2.7 & 1.1 & 0.60 & 0.20 & 0.20 & 0.17 & $<0.1$ & $<0.1$ & $<0.1$ & $<0.1$ \\
\hline $\begin{array}{l}\text { Dissolved microcystin } \\
\qquad(\mu \mathrm{g} / \mathrm{L})\end{array}$ & -- & -- & -- & 0.15 & $\mathrm{~nm}$ & $\mathrm{~nm}$ & $\mathrm{~nm}$ & $\mathrm{~nm}$ & $\mathrm{~nm}$ & $\mathrm{~nm}$ & $\mathrm{~nm}$ \\
\hline Total anatoxin-a $(\mu \mathrm{g} / \mathrm{L})$ & $<0.1$ & $\mathrm{~nm}$ & $\mathrm{~nm}$ & $\mathrm{~nm}$ & $\mathrm{~nm}$ & $\mathrm{~nm}$ & $\mathrm{~nm}$ & $\mathrm{~nm}$ & $\mathrm{~nm}$ & $\mathrm{~nm}$ & $\mathrm{~nm}$ \\
\hline $\begin{array}{l}\text { Total cylindrospermopsin } \\
\qquad(\mu \mathrm{g} / \mathrm{L})\end{array}$ & $<0.05$ & $\mathrm{~nm}$ & $\mathrm{~nm}$ & $\mathrm{~nm}$ & $\mathrm{~nm}$ & $\mathrm{~nm}$ & $\mathrm{~nm}$ & $\mathrm{~nm}$ & $\mathrm{~nm}$ & $\mathrm{~nm}$ & $\mathrm{~nm}$ \\
\hline Total saxitoxin $(\mu \mathrm{g} / \mathrm{L})$ & $<0.02$ & $\mathrm{~nm}$ & $\mathrm{~nm}$ & $\mathrm{~nm}$ & $\mathrm{~nm}$ & $\mathrm{~nm}$ & $\mathrm{~nm}$ & $\mathrm{~nm}$ & $\mathrm{~nm}$ & $\mathrm{~nm}$ & $\mathrm{~nm}$ \\
\hline Total geosmin (ng/L) & $<2.0$ & 7.1 & 6.9 & 6.4 & 5.2 & 10 & 8.4 & $\mathrm{~nm}$ & $\mathrm{~nm}$ & $\mathrm{~nm}$ & $\mathrm{~nm}$ \\
\hline $\begin{array}{l}\text { Total 2-methylisoborneol } \\
\text { (ng/L) }\end{array}$ & $<2.0$ & $<2.0$ & 2.7 & 5.2 & 4.8 & $<2.0$ & $<2.0$ & $\mathrm{~nm}$ & $\mathrm{~nm}$ & $\mathrm{~nm}$ & $\mathrm{~nm}$ \\
\hline
\end{tabular}


Appendix 2. Discrete water-quality sampling results from samples collected from Kansas River tributary and main-stem sites during September and October 2011. - Continued

[nr, near; KS, Kansas; $\mu \mathrm{S} / \mathrm{cm}$, microsiemens per centimeter at 25 degrees Celsius; --, sample not collected; ${ }^{\circ} \mathrm{C}$, degrees Celsius; FNU, formazin nephelometric units; $\mathrm{mg} / \mathrm{L}$, milligrams per liter; \%, percent; $\mu \mathrm{g} / \mathrm{L}$, micrograms per liter; >, greater than; nm, analyte not measured but sample archived; <, less than; ng/L, nanograms per liter; $\mathrm{ft}^{3} / \mathrm{s}$, cubic feet per second; se, sonde measurement error; R, River; Pl, Plaza]

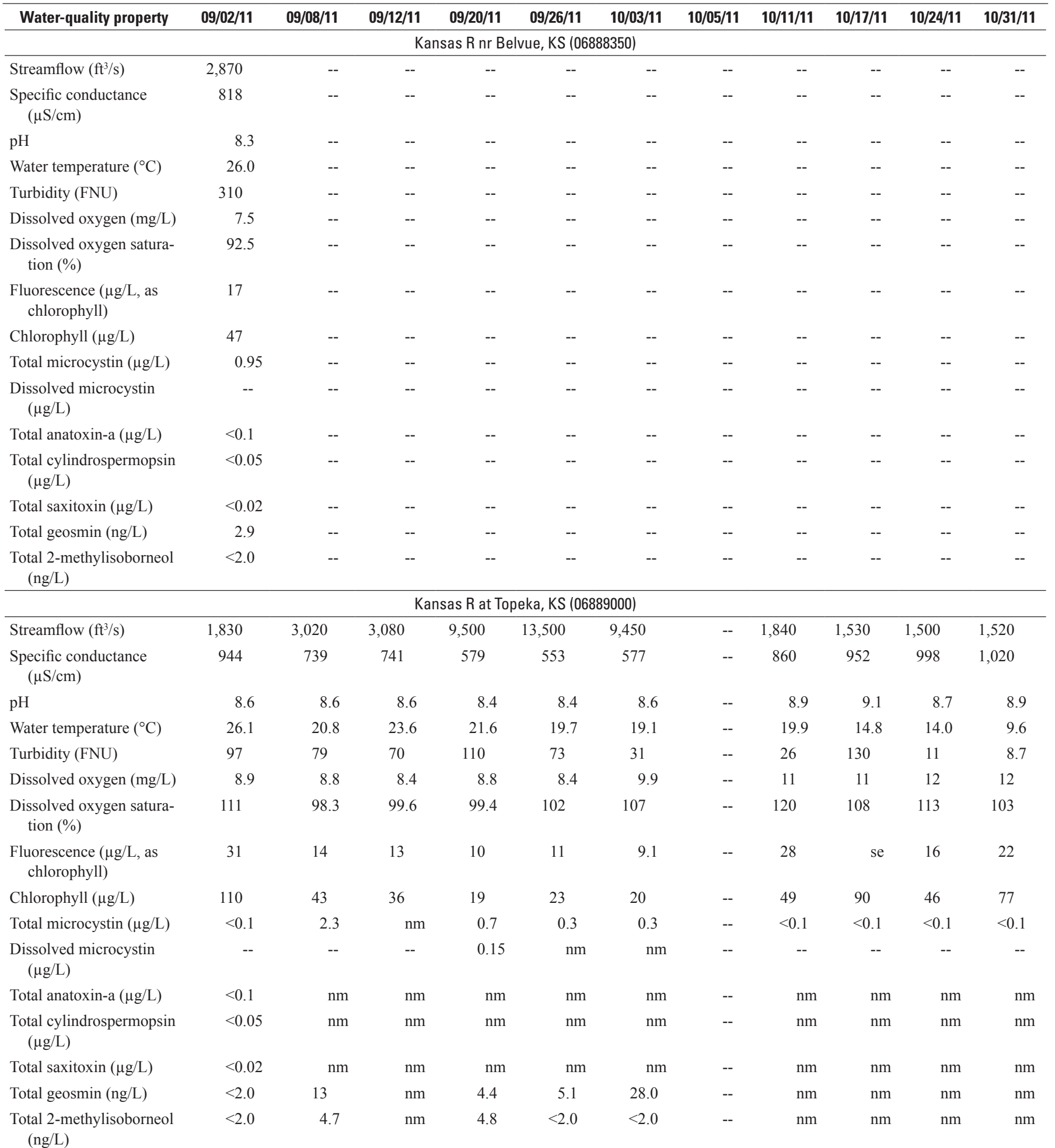


Appendix 2. Discrete water-quality sampling results from samples collected from Kansas River tributary and main-stem sites during September and October 2011.-Continued

[nr, near; KS, Kansas; $\mu \mathrm{S} / \mathrm{cm}$, microsiemens per centimeter at 25 degrees Celsius; --, sample not collected; ${ }^{\circ} \mathrm{C}$, degrees Celsius; FNU, formazin nephelometric units; mg/L, milligrams per liter; \%, percent; $\mu \mathrm{g} / \mathrm{L}$, micrograms per liter; >, greater than; nm, analyte not measured but sample archived; <, less than; ng/L, nanograms per liter; $\mathrm{ft}^{3} / \mathrm{s}$, cubic feet per second; se, sonde measurement error; R, River; Pl, Plaza]

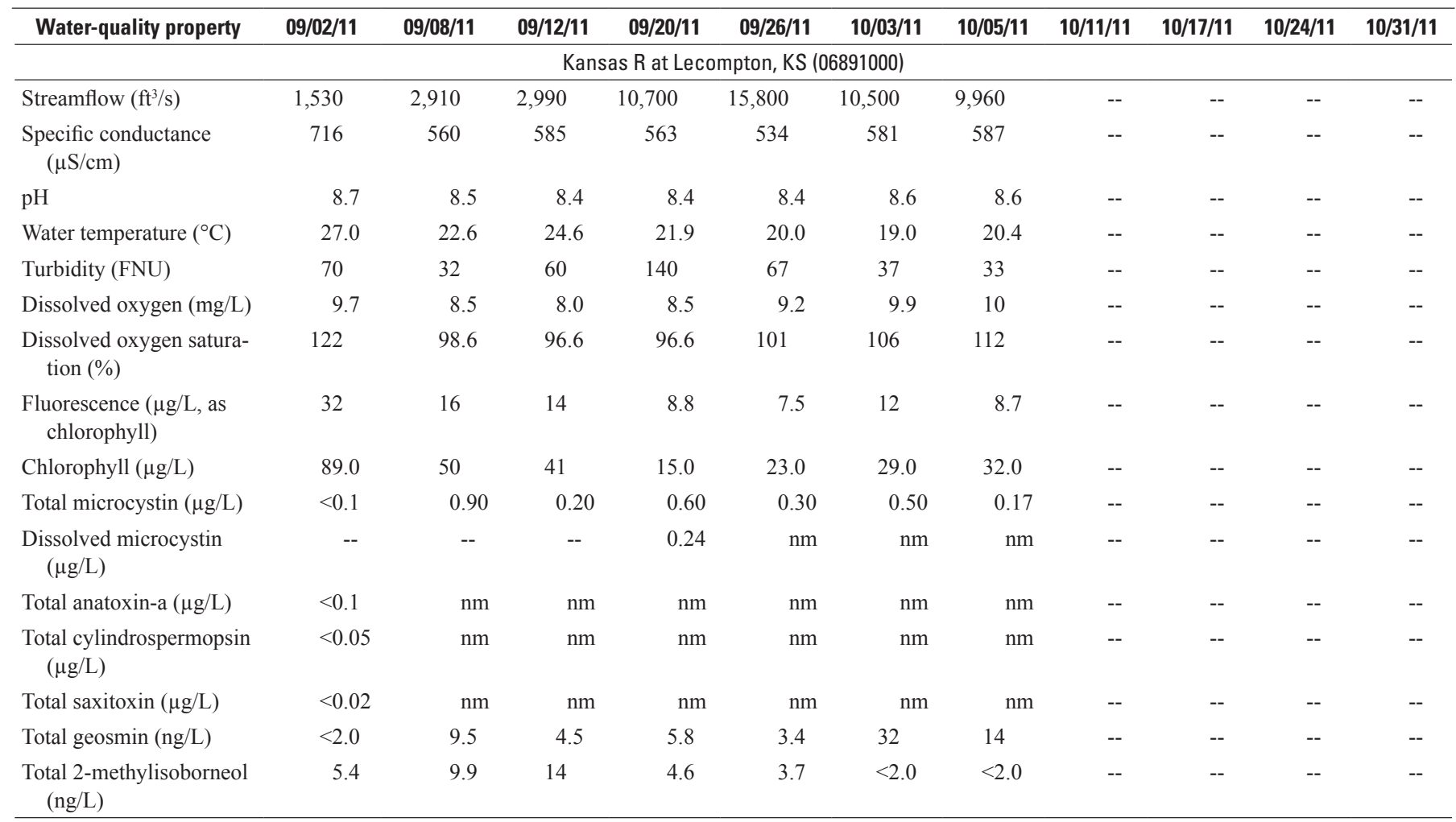

Specific conductance
$(\mu \mathrm{S} / \mathrm{cm})$

Kansas $\mathrm{R}$ at Lawrence, KS (06891080)

$\mathrm{pH}$

Water temperature $\left({ }^{\circ} \mathrm{C}\right)$

Turbidity (FNU)

Dissolved oxygen (mg/L)

Dissolved oxygen saturation (\%)

Fluorescence ( $\mu \mathrm{g} / \mathrm{L}$, as chlorophyll)

Chlorophyll $(\mu \mathrm{g} / \mathrm{L})$

Total microcystin $(\mu \mathrm{g} / \mathrm{L})$

Dissolved microcystin $(\mu \mathrm{g} / \mathrm{L})$

Total anatoxin-a $(\mu \mathrm{g} / \mathrm{L})$

Total cylindrospermopsin $(\mu \mathrm{g} / \mathrm{L})$

Total saxitoxin $(\mu \mathrm{g} / \mathrm{L})$

Total geosmin (ng/L)

Total 2-methylisoborneol (ng/L)

\section{$\begin{array}{llll}-- & 560 & 551 & 549\end{array}$}

$\begin{array}{llllll}-- & - & - & & & \\ - & - & -3 & 8.5 & 8.5\end{array}$

$\begin{array}{rrrrrr}-- & - & - & 8.3 & & 8.5 \\ - & -- & -- & 20.5 & 18.8 & 18.2\end{array}$

$\begin{array}{llllll}- & - & - & 170 & 87 & 38\end{array}$

$\begin{array}{rrrrrr}-- & - & - & 170 & & \\ -- & -- & -- & 8.3 & 8.8 & 9.3\end{array}$

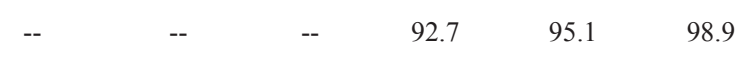

\begin{tabular}{|c|c|c|c|}
\hline -- & -- & 8.8 & 9.4 \\
\hline
\end{tabular}

$\begin{array}{lllllll}-- & -- & - & 13 & 19 & 35\end{array}$

$\begin{array}{lllllll}-- & - & - & - & 0.60 & 0.30 & 0.70\end{array}$

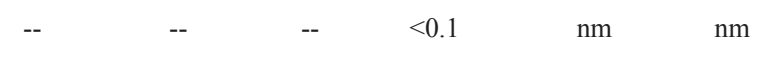


Appendix 2. Discrete water-quality sampling results from samples collected from Kansas River tributary and main-stem sites during September and October 2011.-Continued

[nr, near; KS, Kansas; $\mu \mathrm{S} / \mathrm{cm}$, microsiemens per centimeter at 25 degrees Celsius; --, sample not collected; ${ }^{\circ} \mathrm{C}$, degrees Celsius; FNU, formazin nephelometric units; $\mathrm{mg} / \mathrm{L}$, milligrams per liter; \%, percent; $\mu \mathrm{g} / \mathrm{L}$, micrograms per liter; >, greater than; nm, analyte not measured but sample archived; <, less than; ng/L, nanograms per liter; $\mathrm{ft}^{3} / \mathrm{s}$, cubic feet per second; se, sonde measurement error; R, River; Pl, Plaza]

\begin{tabular}{|c|c|c|c|c|c|c|c|c|c|c|c|}
\hline Water-quality property & $09 / 02 / 11$ & 09/08/11 & 09/12/11 & $09 / 20 / 11$ & $09 / 26 / 11$ & $10 / 03 / 11$ & $10 / 05 / 11$ & 10/11/11 & $10 / 17 / 11$ & $10 / 24 / 11$ & $10 / 31 / 11$ \\
\hline \multicolumn{12}{|c|}{ Kansas R at Desoto, KS (06892350) } \\
\hline Streamflow $\left(\mathrm{ft}^{3} / \mathrm{s}\right)$ & 1,650 & 2,960 & 2,990 & 10,300 & 15,800 & 11,000 & -- & 2,290 & 1,740 & 1,480 & 1,280 \\
\hline $\begin{array}{l}\text { Specific conductance } \\
\qquad(\mu \mathrm{S} / \mathrm{cm})\end{array}$ & 850 & 701 & 665 & 537 & 516 & 545 & -- & 764 & 871 & 950 & 999 \\
\hline $\mathrm{pH}$ & 8.3 & 8.6 & 8.5 & 8.4 & 8.6 & 8.7 & -- & 9.0 & 9.1 & 8.8 & 8.4 \\
\hline Water temperature $\left({ }^{\circ} \mathrm{C}\right)$ & 26.6 & 19.9 & 25.5 & 21.1 & 19.1 & 18.7 & -- & 21.3 & 15.2 & 13.3 & 10.5 \\
\hline $\begin{array}{l}\text { Dissolved oxygen satura- } \\
\text { tion (\%) }\end{array}$ & 104 & 91.6 & 90.4 & 96.6 & 100 & 102 & -- & 134 & 102 & 104 & 103 \\
\hline $\begin{array}{l}\text { Fluorescence }(\mu \mathrm{g} / \mathrm{L} \text {, as } \\
\text { chlorophyll) }\end{array}$ & 37 & 28 & 19 & 16 & 74 & 14 & -- & 30 & se & 34 & 34 \\
\hline Chlorophyll $(\mu \mathrm{g} / \mathrm{L})$ & 110 & 85 & 58 & 15 & 19 & 42 & -- & 48 & 100 & 86 & 97 \\
\hline Total anatoxin-a $(\mu \mathrm{g} / \mathrm{L})$ & $<0.1$ & $\mathrm{~nm}$ & $\mathrm{~nm}$ & $\mathrm{~nm}$ & $\mathrm{~nm}$ & $\mathrm{~nm}$ & -- & $\mathrm{nm}$ & $\mathrm{nm}$ & $\mathrm{nm}$ & $\mathrm{nm}$ \\
\hline $\begin{array}{l}\text { Total cylindrospermopsin } \\
\qquad(\mu \mathrm{g} / \mathrm{L})\end{array}$ & $<0.05$ & $\mathrm{~nm}$ & $\mathrm{~nm}$ & $\mathrm{~nm}$ & $\mathrm{~nm}$ & $\mathrm{~nm}$ & -- & $\mathrm{nm}$ & $\mathrm{nm}$ & $\mathrm{nm}$ & $\mathrm{nm}$ \\
\hline Total saxitoxin $(\mu \mathrm{g} / \mathrm{L})$ & $<0.02$ & $\mathrm{~nm}$ & $\mathrm{~nm}$ & $\mathrm{~nm}$ & $\mathrm{~nm}$ & $\mathrm{~nm}$ & -- & $\mathrm{nm}$ & $\mathrm{nm}$ & $\mathrm{nm}$ & $\mathrm{nm}$ \\
\hline Total geosmin $(\mathrm{ng} / \mathrm{L})$ & $<2.0$ & 5.1 & 5.1 & 3.1 & 7.6 & 35 & -- & 4.6 & $<2.0$ & $<2.0$ & $<2.0$ \\
\hline $\begin{array}{l}\text { Total 2-methylisoborneol } \\
\text { (ng/L) }\end{array}$ & $<2.0$ & 16 & 2.9 & $<2.0$ & 2.8 & $<2.0$ & -- & $<2.0$ & $<2.0$ & $<2.0$ & $<2.0$ \\
\hline \multicolumn{12}{|c|}{ Kansas R nr I-435 Bridge, KS (06892518) } \\
\hline $\begin{array}{l}\text { Specific conductance } \\
\quad(\mu \mathrm{S} / \mathrm{cm})\end{array}$ & 829 & 709 & 713 & 537 & 516 & 523 & -- & -- & -- & -- & -- \\
\hline $\mathrm{pH}$ & 8.7 & 8.7 & 8.7 & 8.3 & 8.4 & 8.6 & -- & -- & -- & -- & -- \\
\hline Chlorophyll $(\mu \mathrm{g} / \mathrm{L})$ & 140 & 89 & 61 & 16 & 26 & 39 & -- & -- & -- & -- & -- \\
\hline Total microcystin $(\mu \mathrm{g} / \mathrm{L})$ & $<0.1$ & 0.80 & $\mathrm{~nm}$ & $\mathrm{~nm}$ & $\mathrm{~nm}$ & $\mathrm{~nm}$ & -- & -- & -- & -- & -- \\
\hline $\begin{array}{l}\text { Dissolved microcystin } \\
\qquad(\mu \mathrm{g} / \mathrm{L})\end{array}$ & -- & -- & -- & $\mathrm{nm}$ & $\mathrm{nm}$ & $\mathrm{nm}$ & -- & -- & -- & -- & -- \\
\hline Total anatoxin-a $(\mu \mathrm{g} / \mathrm{L})$ & $<0.1$ & $\mathrm{~nm}$ & $\mathrm{~nm}$ & $\mathrm{~nm}$ & $\mathrm{~nm}$ & $\mathrm{~nm}$ & -- & -- & -- & -- & -- \\
\hline $\begin{array}{l}\text { Total cylindrospermopsin } \\
\qquad(\mu \mathrm{g} / \mathrm{L})\end{array}$ & $<0.05$ & $\mathrm{~nm}$ & $\mathrm{~nm}$ & $\mathrm{~nm}$ & $\mathrm{~nm}$ & $\mathrm{~nm}$ & -- & -- & -- & -- & -- \\
\hline Total saxitoxin $(\mu \mathrm{g} / \mathrm{L})$ & $<0.02$ & $\mathrm{~nm}$ & $\mathrm{~nm}$ & $\mathrm{~nm}$ & $\mathrm{~nm}$ & $\mathrm{~nm}$ & -- & -- & -- & -- & -- \\
\hline Total geosmin (ng/L) & $<2.0$ & 4.3 & $\mathrm{~nm}$ & $\mathrm{~nm}$ & -- & $\mathrm{nm}$ & -- & -- & -- & -- & -- \\
\hline $\begin{array}{l}\text { Total 2-methylisoborneol } \\
\text { (ng/L) }\end{array}$ & $<2.0$ & 5.0 & $\mathrm{~nm}$ & $\mathrm{~nm}$ & -- & $\mathrm{nm}$ & -- & -- & -- & -- & -- \\
\hline
\end{tabular}


Appendix 3. Cyanobacterial community composition in samples collected from Kansas River tributary and main-stem sites during September and October 2011.

[cells/mL, cells per milliliter; \%, percent; nr, near; KS, Kansas; --, sample not collected; nm, analyte not measured but sample archived; R, River; Pl, Plaza]

\begin{tabular}{|c|c|c|c|c|c|c|c|c|c|c|}
\hline Date & $\begin{array}{c}\text { Cyanobacteria } \\
\text { abundance } \\
\text { (cells/mL) }\end{array}$ & $\begin{array}{c}\text { Anabaena } \\
\text { abundance } \\
\text { (cells/mL) }\end{array}$ & $\begin{array}{c}\text { Anabae- } \\
\text { nopsis } \\
\text { abundance } \\
\text { (cells/mL) }\end{array}$ & $\begin{array}{l}\text { Aphanizo- } \\
\text { menon } \\
\text { abundance } \\
\text { (cells/mL }\end{array}$ & $\begin{array}{c}\text { Aphano- } \\
\text { capsa } \\
\text { abundance } \\
\text { (cells/mL) }\end{array}$ & $\begin{array}{c}\text { Chroococ- } \\
\text { cus } \\
\text { abundance } \\
\text { (cells/mL) }\end{array}$ & $\begin{array}{l}\text { Cylindro- } \\
\text { spermopsis } \\
\text { abundance } \\
\text { (cells/mL) }\end{array}$ & $\begin{array}{c}\text { Microcystis } \\
\text { abundance } \\
\text { (cells/mL) }\end{array}$ & $\begin{array}{l}\text { Phormidium } \\
\text { abundance } \\
\text { (cells/mL) }\end{array}$ & $\begin{array}{c}\text { Pseudana- } \\
\text { baena } \\
\text { abundance } \\
\text { (cells } / \mathrm{mL} \text { ) }\end{array}$ \\
\hline \multicolumn{11}{|c|}{ Milford Reservoir sampling sites } \\
\hline \multicolumn{11}{|c|}{ Milford Lake nr Junction City, KS (06857050) } \\
\hline $09 / 02 / 11$ & $600,000,000$ & 0 & 0 & 0 & 0 & 0 & 0 & $600,000,000$ & 0.0 & 0.0 \\
\hline $09 / 08 / 11$ & -- & -- & -- & -- & -- & -- & -- & -- & -- & -- \\
\hline $09 / 12 / 11$ & -- & -- & -- & -- & -- & -- & -- & -- & -- & -- \\
\hline $09 / 20 / 11$ & -- & -- & -- & -- & -- & -- & -- & -- & -- & -- \\
\hline $09 / 26 / 11$ & $\mathrm{~nm}$ & $\mathrm{~nm}$ & $\mathrm{~nm}$ & $\mathrm{~nm}$ & $\mathrm{~nm}$ & $\mathrm{~nm}$ & $\mathrm{~nm}$ & $\mathrm{~nm}$ & $\mathrm{~nm}$ & $\mathrm{~nm}$ \\
\hline $10 / 03 / 11$ & $\mathrm{~nm}$ & $\mathrm{~nm}$ & $\mathrm{~nm}$ & $\mathrm{~nm}$ & $\mathrm{~nm}$ & $\mathrm{~nm}$ & $\mathrm{~nm}$ & $\mathrm{~nm}$ & $\mathrm{~nm}$ & $\mathrm{~nm}$ \\
\hline $10 / 05 / 11$ & -- & -- & -- & -- & -- & -- & -- & -- & -- & -- \\
\hline $10 / 11 / 11$ & -- & -- & -- & -- & -- & -- & -- & -- & -- & -- \\
\hline $10 / 17 / 11$ & -- & -- & -- & -- & -- & -- & -- & -- & -- & -- \\
\hline $10 / 24 / 11$ & -- & -- & -- & -- & -- & -- & -- & -- & -- & -- \\
\hline $10 / 31 / 11$ & -- & -- & -- & -- & -- & -- & -- & -- & -- & -- \\
\hline \multicolumn{11}{|c|}{ Milford Lake outlet, KS (390433096534600) } \\
\hline $09 / 02 / 11$ & 28,000 & 20 & 0.0 & 0.0 & 0.0 & 21 & 0.0 & 28,000 & 0.0 & 0.0 \\
\hline $09 / 08 / 11$ & 17,000 & 4.0 & 76 & 0.0 & 0.0 & 0.0 & 0.0 & 16,000 & 0.0 & 29 \\
\hline $09 / 12 / 11$ & $\mathrm{~nm}$ & $\mathrm{~nm}$ & $\mathrm{~nm}$ & $\mathrm{~nm}$ & $\mathrm{~nm}$ & $\mathrm{~nm}$ & $\mathrm{~nm}$ & $\mathrm{~nm}$ & $\mathrm{~nm}$ & $\mathrm{~nm}$ \\
\hline $09 / 20 / 11$ & $\mathrm{~nm}$ & $\mathrm{~nm}$ & $\mathrm{~nm}$ & $\mathrm{~nm}$ & $\mathrm{~nm}$ & $\mathrm{~nm}$ & $\mathrm{~nm}$ & $\mathrm{~nm}$ & $\mathrm{~nm}$ & $\mathrm{~nm}$ \\
\hline $09 / 26 / 11$ & $\mathrm{~nm}$ & $\mathrm{~nm}$ & $\mathrm{~nm}$ & $\mathrm{~nm}$ & $\mathrm{~nm}$ & $\mathrm{~nm}$ & $\mathrm{~nm}$ & $\mathrm{~nm}$ & $\mathrm{~nm}$ & $\mathrm{~nm}$ \\
\hline $10 / 03 / 11$ & $\mathrm{~nm}$ & $\mathrm{~nm}$ & $\mathrm{~nm}$ & $\mathrm{~nm}$ & $\mathrm{~nm}$ & $\mathrm{~nm}$ & $\mathrm{~nm}$ & $\mathrm{~nm}$ & $\mathrm{~nm}$ & $\mathrm{~nm}$ \\
\hline $10 / 05 / 11$ & -- & -- & -- & -- & -- & -- & -- & -- & -- & -- \\
\hline $10 / 11 / 11$ & -- & -- & -- & -- & -- & -- & -- & -- & -- & -- \\
\hline $10 / 17 / 11$ & -- & -- & -- & -- & -- & -- & -- & -- & -- & -- \\
\hline $10 / 24 / 11$ & -- & -- & -- & -- & -- & -- & -- & -- & -- & -- \\
\hline $10 / 31 / 11$ & -- & -- & -- & -- & -- & -- & -- & -- & -- & -- \\
\hline \multicolumn{11}{|c|}{ Kansas River tributary sampling sites } \\
\hline \multicolumn{11}{|c|}{ Smoky Hill R at Grandview PI, Junction City, KS (06879005) } \\
\hline $09 / 02 / 11$ & 0.0 & 0.0 & 0.0 & 0.0 & 0.0 & 0.0 & 0.0 & 0.0 & 0.0 & 0.0 \\
\hline $09 / 08 / 11$ & 0.0 & 0.0 & 0.0 & 0.0 & 0.0 & 0.0 & 0.0 & 0.0 & 0.0 & 0.0 \\
\hline $09 / 12 / 11$ & 0.0 & 0.0 & 0.0 & 0.0 & 0.0 & 0.0 & 0.0 & 0.0 & 0.0 & 0.0 \\
\hline $09 / 20 / 11$ & 0.0 & 0.0 & 0.0 & 0.0 & 0.0 & 0.0 & 0.0 & 0.0 & 0.0 & 0.0 \\
\hline $09 / 26 / 11$ & 72 & 0.0 & 0.0 & 42 & 0.0 & 0.0 & 0.0 & 0.0 & 0.0 & 0.0 \\
\hline $10 / 03 / 11$ & 560 & 0.0 & 0.0 & 560 & 0.0 & 0.0 & 0.0 & 0.0 & 0.0 & 0.0 \\
\hline $10 / 05 / 11$ & -- & -- & -- & -- & -- & -- & -- & -- & -- & -- \\
\hline $10 / 11 / 11$ & -- & -- & -- & -- & -- & -- & -- & -- & -- & -- \\
\hline $10 / 17 / 11$ & -- & -- & -- & -- & -- & -- & -- & -- & -- & -- \\
\hline $10 / 24 / 11$ & -- & -- & -- & -- & -- & -- & -- & -- & -- & -- \\
\hline $10 / 31 / 11$ & -- & -- & -- & -- & -- & -- & -- & -- & -- & -- \\
\hline
\end{tabular}


Appendix 3. Cyanobacterial community composition in samples collected from Kansas River tributary and main-stem sites during September and October 2011.-Continued

[cells/mL, cells per milliliter; \%, percent; nr, near; KS, Kansas; --, sample not collected; nm, analyte not measured but sample archived; R, River; Pl, Plaza]

\begin{tabular}{|c|c|c|c|c|c|c|c|c|c|}
\hline Date & $\begin{array}{c}\text { Anabaena } \\
\text { relative } \\
\text { abundance } \\
(\%)\end{array}$ & $\begin{array}{l}\text { Anabaenopsis } \\
\text { relative } \\
\text { abundance } \\
(\%)\end{array}$ & $\begin{array}{c}\text { Aphanizo- } \\
\text { menon } \\
\text { relative } \\
\text { abundance } \\
(\%)\end{array}$ & $\begin{array}{c}\text { Aphanocapsa } \\
\text { relative } \\
\text { abundance } \\
(\%)\end{array}$ & $\begin{array}{c}\text { Chroococcus } \\
\text { relative } \\
\text { abundance } \\
(\%)\end{array}$ & $\begin{array}{c}\text { Cylindrosper- } \\
\text { mopsis } \\
\text { relative } \\
\text { abundance } \\
(\%)\end{array}$ & $\begin{array}{l}\text { Microcystis } \\
\text { relative } \\
\text { abundance } \\
(\%)\end{array}$ & $\begin{array}{c}\text { Phormidium } \\
\text { relative } \\
\text { abundance } \\
(\%)\end{array}$ & $\begin{array}{c}\text { Pseudanbaena } \\
\text { relative } \\
\text { abundance } \\
(\%)\end{array}$ \\
\hline \multicolumn{10}{|c|}{ Milford Reservoir sampling sites } \\
\hline \multicolumn{10}{|c|}{ Milford Lake nr Junction City, KS (06857050) } \\
\hline $09 / 02 / 11$ & 0.0 & 0.0 & 0.0 & 0.0 & 0.0 & 0.0 & 100 & 0.0 & 0.0 \\
\hline 09/08/11 & -- & -- & -- & -- & -- & -- & -- & -- & -- \\
\hline $09 / 12 / 11$ & -- & -- & -- & -- & -- & -- & -- & -- & -- \\
\hline $09 / 20 / 11$ & -- & -- & -- & -- & -- & -- & -- & -- & -- \\
\hline $09 / 26 / 11$ & $\mathrm{~nm}$ & $\mathrm{~nm}$ & $\mathrm{~nm}$ & $\mathrm{~nm}$ & $\mathrm{~nm}$ & $\mathrm{~nm}$ & $\mathrm{~nm}$ & $\mathrm{~nm}$ & $\mathrm{~nm}$ \\
\hline $10 / 03 / 11$ & $\mathrm{~nm}$ & $\mathrm{~nm}$ & $\mathrm{~nm}$ & $\mathrm{~nm}$ & $\mathrm{~nm}$ & $\mathrm{~nm}$ & $\mathrm{~nm}$ & $\mathrm{~nm}$ & $\mathrm{~nm}$ \\
\hline $10 / 05 / 11$ & -- & -- & -- & -- & -- & -- & -- & -- & -- \\
\hline $10 / 11 / 11$ & -- & -- & -- & -- & -- & -- & -- & -- & -- \\
\hline $10 / 17 / 11$ & -- & -- & -- & -- & -- & -- & -- & -- & -- \\
\hline $10 / 24 / 11$ & -- & -- & -- & -- & -- & -- & -- & -- & -- \\
\hline $10 / 31 / 11$ & -- & -- & -- & -- & -- & -- & -- & -- & -- \\
\hline \multicolumn{10}{|c|}{ Milford Lake outlet, KS (390433096534600) } \\
\hline $09 / 02 / 11$ & 0.069 & 0.0 & 0.0 & 0.0 & 0.076 & 0.0 & 100 & 0.0 & 0.0 \\
\hline $09 / 08 / 11$ & 0.024 & 0.46 & 0.0 & 0.0 & 0.0 & 0.0 & 99 & 0.0 & 0.18 \\
\hline $09 / 12 / 11$ & $\mathrm{~nm}$ & $\mathrm{~nm}$ & $\mathrm{~nm}$ & $\mathrm{~nm}$ & $\mathrm{~nm}$ & $\mathrm{~nm}$ & $\mathrm{~nm}$ & $\mathrm{~nm}$ & $\mathrm{~nm}$ \\
\hline $09 / 20 / 11$ & $\mathrm{~nm}$ & $\mathrm{~nm}$ & $\mathrm{~nm}$ & $\mathrm{~nm}$ & $\mathrm{~nm}$ & $\mathrm{~nm}$ & $\mathrm{~nm}$ & $\mathrm{~nm}$ & $\mathrm{~nm}$ \\
\hline $09 / 26 / 11$ & $\mathrm{~nm}$ & $\mathrm{~nm}$ & $\mathrm{~nm}$ & $\mathrm{~nm}$ & $\mathrm{~nm}$ & $\mathrm{~nm}$ & $\mathrm{~nm}$ & $\mathrm{~nm}$ & $\mathrm{~nm}$ \\
\hline $10 / 03 / 11$ & $\mathrm{~nm}$ & $\mathrm{~nm}$ & $\mathrm{~nm}$ & $\mathrm{~nm}$ & $\mathrm{~nm}$ & $\mathrm{~nm}$ & $\mathrm{~nm}$ & $\mathrm{~nm}$ & $\mathrm{~nm}$ \\
\hline $10 / 05 / 11$ & -- & -- & -- & -- & -- & -- & -- & -- & -- \\
\hline $10 / 11 / 11$ & -- & -- & -- & -- & -- & -- & -- & -- & -- \\
\hline $10 / 17 / 11$ & -- & -- & -- & -- & -- & -- & -- & -- & -- \\
\hline $10 / 24 / 11$ & -- & -- & -- & -- & -- & -- & -- & -- & -- \\
\hline $10 / 31 / 11$ & -- & -- & -- & -- & -- & -- & -- & -- & -- \\
\hline \multicolumn{10}{|c|}{ Kansas River tributary sampling sites } \\
\hline \multicolumn{10}{|c|}{ Smoky Hill R at Grandview PI, Junction City, KS (06879005) } \\
\hline $09 / 02 / 11$ & 0.0 & 0.0 & 0.0 & 0.0 & 0.0 & 0.0 & 0.0 & 0.0 & 0.0 \\
\hline $09 / 08 / 11$ & 0.0 & 0.0 & 0.0 & 0.0 & 0.0 & 0.0 & 0.0 & 0.0 & 0.0 \\
\hline $09 / 12 / 11$ & 0.0 & 0.0 & 0.0 & 0.0 & 0.0 & 0.0 & 0.0 & 0.0 & 0.0 \\
\hline $09 / 20 / 11$ & 0.0 & 0.0 & 0.0 & 0.0 & 0.0 & 0.0 & 0.0 & 0.0 & 0.0 \\
\hline $09 / 26 / 11$ & 0.0 & 0.0 & 100 & 0.0 & 0.0 & 0.0 & 0.0 & 0.0 & 0.0 \\
\hline $10 / 03 / 11$ & 0.0 & 0.0 & 100 & 0.0 & 0.0 & 0.0 & 0.0 & 0.0 & 0.0 \\
\hline $10 / 05 / 11$ & -- & -- & -- & -- & -- & -- & -- & -- & -- \\
\hline $10 / 11 / 11$ & -- & -- & -- & -- & -- & -- & -- & -- & -- \\
\hline $10 / 17 / 11$ & -- & -- & -- & -- & -- & -- & -- & -- & -- \\
\hline $10 / 24 / 11$ & -- & -- & -- & -- & -- & -- & -- & -- & -- \\
\hline $10 / 31 / 11$ & -- & -- & -- & -- & -- & -- & -- & -- & -- \\
\hline
\end{tabular}


Appendix 3. Cyanobacterial community composition in samples collected from Kansas River tributary and main-stem sites during September and October 2011.-Continued

[cells/mL, cells per milliliter; \%, percent; nr, near; KS, Kansas; --, sample not collected; nm, analyte not measured but sample archived; R, River; Pl, Plaza]

\begin{tabular}{|c|c|c|c|c|c|c|c|c|c|c|}
\hline Date & $\begin{array}{l}\text { Cyanobacteria } \\
\text { abundance } \\
\text { (cells/mL) }\end{array}$ & $\begin{array}{c}\text { Anabaena } \\
\text { abundance } \\
\text { (cells/mL) }\end{array}$ & $\begin{array}{c}\text { Anabae- } \\
\text { nopsis } \\
\text { abundance } \\
\text { (cells/mL) }\end{array}$ & $\begin{array}{l}\text { Aphanizo- } \\
\text { menon } \\
\text { abundance } \\
\text { (cells/mL }\end{array}$ & $\begin{array}{l}\text { Aphano- } \\
\text { capsa } \\
\text { abundance } \\
\text { (cells/mL) }\end{array}$ & $\begin{array}{l}\text { Chroococ- } \\
\text { cus } \\
\text { abundance } \\
\text { (cells } / \mathrm{mL} \text { ) }\end{array}$ & $\begin{array}{l}\text { Cylindro- } \\
\text { spermopsis } \\
\text { abundance } \\
\text { (cells/mL) }\end{array}$ & $\begin{array}{l}\text { Microcystis } \\
\text { abundance } \\
\text { (cells/mL) }\end{array}$ & $\begin{array}{l}\text { Phormidium } \\
\text { abundance } \\
\text { (cells/mL) }\end{array}$ & $\begin{array}{l}\text { Pseudana- } \\
\text { baena } \\
\text { abundance } \\
\text { (cells } / \mathrm{mL} \text { ) }\end{array}$ \\
\hline \multicolumn{11}{|c|}{ Republican R at Junction City, KS (06857100) } \\
\hline $09 / 02 / 11$ & 28,000 & 340 & 0.0 & 0.0 & 0.0 & 0.0 & 0.0 & 28,000 & 210 & 25 \\
\hline $09 / 08 / 11$ & 25,000 & 360 & 180 & 0.0 & 0.0 & 0.0 & 0.0 & 24,000 & 0.0 & 890 \\
\hline $09 / 12 / 11$ & 3,700 & 500 & 0.0 & 0.0 & 0.0 & 0.0 & 240 & 2,700 & 290 & 0.0 \\
\hline $09 / 20 / 11$ & 760 & 110 & 0.0 & 0.0 & 0.0 & 7.0 & 0.0 & 640 & 0.0 & 0.0 \\
\hline $09 / 26 / 11$ & 380 & 110 & 0.0 & 0.0 & 0.0 & 0.0 & 0.0 & 280 & 0.0 & 0.0 \\
\hline $10 / 03 / 11$ & 380 & 270 & 0.0 & 21 & 0.0 & 0.0 & 0.0 & 86 & 0.0 & 0.0 \\
\hline $10 / 05 / 11$ & -- & -- & -- & -- & -- & -- & -- & -- & -- & -- \\
\hline $10 / 11 / 11$ & 230 & 74 & 0.0 & 0.0 & 0.0 & 0.0 & 0.0 & 150 & 0.0 & 0.0 \\
\hline $10 / 17 / 11$ & 0.0 & 0.0 & 0.0 & 0.0 & 0.0 & 0.0 & 0.0 & 0.0 & 0.0 & 0.0 \\
\hline $10 / 24 / 11$ & 0.0 & 0.0 & 0.0 & 0.0 & 0.0 & 0.0 & 0.0 & 0.0 & 0.0 & 0.0 \\
\hline $10 / 31 / 11$ & 0.0 & 0.0 & 0.0 & 0.0 & 0.0 & 0.0 & 0.0 & 0.0 & 0.0 & 0.0 \\
\hline \multicolumn{11}{|c|}{ Big Blue R nr Manhattan, KS (06887000) } \\
\hline $09 / 02 / 11$ & 0.0 & 0.0 & 0.0 & 0.0 & 0.0 & 0.0 & 0.0 & 0.0 & 0.0 & 0.0 \\
\hline $09 / 08 / 11$ & 830 & 210 & 0.0 & 0.0 & 0.0 & 0.0 & 0.0 & 360 & 0.0 & 260 \\
\hline $09 / 12 / 11$ & 0.0 & 0.0 & 0.0 & 0.0 & 0.0 & 0.0 & 0.0 & 0.0 & 0.0 & 0.0 \\
\hline $09 / 20 / 11$ & 0.0 & 0.0 & 0.0 & 0.0 & 0.0 & 0.0 & 0.0 & 0.0 & 0.0 & 0.0 \\
\hline $09 / 26 / 11$ & 0.0 & 0.0 & 0.0 & 0.0 & 0.0 & 0.0 & 0.0 & 0.0 & 0.0 & 0.0 \\
\hline $10 / 03 / 11$ & 0.0 & 0.0 & 0.0 & 0.0 & 0.0 & 0.0 & 0.0 & 0.0 & 0.0 & 0.0 \\
\hline $10 / 05 / 11$ & -- & -- & -- & -- & -- & -- & -- & -- & -- & -- \\
\hline $10 / 11 / 11$ & 0.0 & 0.0 & 0.0 & 0.0 & 0.0 & 0.0 & 0.0 & 0.0 & 0.0 & 0.0 \\
\hline $10 / 17 / 11$ & 0.0 & 0.0 & 0.0 & 0.0 & 0.0 & 0.0 & 0.0 & 0.0 & 0.0 & 0.0 \\
\hline $10 / 24 / 11$ & 0.0 & 0.0 & 0.0 & 0.0 & 0.0 & 0.0 & 0.0 & 0.0 & 0.0 & 0.0 \\
\hline $10 / 31 / 11$ & 0.0 & 0.0 & 0.0 & 0.0 & 0.0 & 0.0 & 0.0 & 0.0 & 0.0 & 0.0 \\
\hline \multicolumn{11}{|c|}{ Delaware R at Perry, KS (06890900) } \\
\hline $09 / 02 / 11$ & 43 & 0.0 & 0.0 & 0.0 & 0.0 & 43 & 0.0 & 0.0 & 0.0 & 0.0 \\
\hline 09/08/11 & 2,500 & 3.6 & 16 & 0.0 & 0.0 & 140 & 0.0 & 1,000 & 210 & 1,200 \\
\hline $09 / 12 / 11$ & 0.0 & 0.0 & 0 & 0.0 & 0.0 & 0.0 & 0.0 & 0.0 & 0.0 & 0.0 \\
\hline $09 / 20 / 11$ & 0.0 & 0.0 & 0 & 0.0 & 0.0 & 0.0 & 0.0 & 0.0 & 0.0 & 0.0 \\
\hline $09 / 26 / 11$ & 0.0 & 0.0 & 0 & 0.0 & 0.0 & 0.0 & 0.0 & 0.0 & 0.0 & 0.0 \\
\hline $10 / 03 / 11$ & -- & -- & -- & -- & -- & -- & -- & -- & -- & -- \\
\hline $10 / 05 / 11$ & -- & -- & -- & -- & -- & -- & -- & -- & -- & -- \\
\hline $10 / 11 / 11$ & 49 & 49 & 0.0 & 0.0 & 0.0 & 0.0 & 0.0 & 0.0 & 0.0 & 0.0 \\
\hline $10 / 17 / 11$ & 95 & 10 & 0.0 & 69 & 0.0 & 0.0 & 0.0 & 16 & 0.0 & 0.0 \\
\hline $10 / 24 / 11$ & 160 & 34 & 0.0 & 120 & 0.0 & 0.0 & 0.0 & 0.0 & 0.0 & 0.0 \\
\hline $10 / 31 / 11$ & 32 & 32 & 0.0 & 0.0 & 0.0 & 0.0 & 0.0 & 0.0 & 0.0 & 0.0 \\
\hline
\end{tabular}


Appendix 3. Cyanobacterial community composition in samples collected from Kansas River tributary and main-stem sites during September and October 2011.-Continued

[cells/mL, cells per milliliter; \%, percent; nr, near; KS, Kansas; --, sample not collected; nm, analyte not measured but sample archived; R, River; Pl, Plaza]

\begin{tabular}{|c|c|c|c|c|c|c|c|c|c|}
\hline Date & $\begin{array}{c}\text { Anabaena } \\
\text { relative } \\
\text { abundance } \\
(\%)\end{array}$ & $\begin{array}{l}\text { Anabaenopsis } \\
\text { relative } \\
\text { abundance } \\
(\%)\end{array}$ & $\begin{array}{c}\text { Aphanizo- } \\
\text { menon } \\
\text { relative } \\
\text { abundance } \\
(\%)\end{array}$ & $\begin{array}{c}\text { Aphanocapsa } \\
\text { relative } \\
\text { abundance } \\
(\%)\end{array}$ & $\begin{array}{c}\text { Chroococcus } \\
\text { relative } \\
\text { abundance } \\
(\%)\end{array}$ & $\begin{array}{c}\text { Cylindrosper- } \\
\text { mopsis } \\
\text { relative } \\
\text { abundance } \\
(\%)\end{array}$ & $\begin{array}{c}\text { Microcystis } \\
\text { relative } \\
\text { abundance } \\
(\%)\end{array}$ & $\begin{array}{c}\text { Phormidium } \\
\text { relative } \\
\text { abundance } \\
(\%)\end{array}$ & $\begin{array}{c}\text { Pseudanbaena } \\
\text { relative } \\
\text { abundance } \\
(\%)\end{array}$ \\
\hline \multicolumn{10}{|c|}{ Republican R at Junction City, KS (06857100) } \\
\hline $09 / 02 / 11$ & 1.2 & 0.0 & 0.0 & 0.0 & 0.0 & 0.0 & 98 & 0.74 & 0.088 \\
\hline 09/08/11 & 1.4 & 0.70 & 0.0 & 0.0 & 0.0 & 0.0 & 94 & 0.0 & 3.5 \\
\hline $09 / 12 / 11$ & 13 & 0.0 & 0.0 & 0.0 & 0.0 & 6.4 & 72 & 7.9 & 0.0 \\
\hline $09 / 20 / 11$ & 14 & 0.0 & 0.0 & 0.0 & 0.92 & 0.0 & 84 & 0.0 & 0.0 \\
\hline $09 / 26 / 11$ & 28 & 0.0 & 0.0 & 0.0 & 0.0 & 0.0 & 72 & 0.0 & 0.0 \\
\hline $10 / 03 / 11$ & 72 & 0.0 & 5.5 & 0.0 & 0.0 & 0.0 & 23 & 0.0 & 0.0 \\
\hline $10 / 05 / 11$ & -- & -- & -- & -- & -- & -- & -- & -- & -- \\
\hline $10 / 11 / 11$ & 33 & 0.0 & 0.0 & 0.0 & 0.0 & 0.0 & 68 & 0.0 & 0.0 \\
\hline $10 / 17 / 11$ & 0.0 & 0.0 & 0.0 & 0.0 & 0.0 & 0.0 & 0.0 & 0.0 & 0.0 \\
\hline $10 / 24 / 11$ & 0.0 & 0.0 & 0.0 & 0.0 & 0.0 & 0.0 & 0.0 & 0.0 & 0.0 \\
\hline $10 / 31 / 11$ & 0.0 & 0.0 & 0.0 & 0.0 & 0.0 & 0.0 & 0.0 & 0.0 & 0.0 \\
\hline \multicolumn{10}{|c|}{ Big Blue R nr Manhattan, KS (06887000) } \\
\hline $09 / 02 / 11$ & 0.0 & 0.0 & 0.0 & 0.0 & 0.0 & 0.0 & 0.0 & 0.0 & 0.0 \\
\hline 09/08/11 & 26 & 0.0 & 0.0 & 0.0 & 0.0 & 0.0 & 43 & 0.0 & 32 \\
\hline $09 / 12 / 11$ & 0.0 & 0.0 & 0.0 & 0.0 & 0.0 & 0.0 & 0.0 & 0.0 & 0.0 \\
\hline 09/20/11 & 0.0 & 0.0 & 0.0 & 0.0 & 0.0 & 0.0 & 0.0 & 0.0 & 0.0 \\
\hline $09 / 26 / 11$ & 0.0 & 0.0 & 0.0 & 0.0 & 0.0 & 0.0 & 0.0 & 0.0 & 0.0 \\
\hline $10 / 03 / 11$ & 0.0 & 0.0 & 0.0 & 0.0 & 0.0 & 0.0 & 0.0 & 0.0 & 0.0 \\
\hline $10 / 05 / 11$ & -- & -- & -- & -- & -- & -- & -- & -- & -- \\
\hline $10 / 11 / 11$ & 0.0 & 0.0 & 0.0 & 0.0 & 0.0 & 0.0 & 0.0 & 0.0 & 0.0 \\
\hline $10 / 17 / 11$ & 0.0 & 0.0 & 0.0 & 0.0 & 0.0 & 0.0 & 0.0 & 0.0 & 0.0 \\
\hline $10 / 24 / 11$ & 0.0 & 0.0 & 0.0 & 0.0 & 0.0 & 0.0 & 0.0 & 0.0 & 0.0 \\
\hline $10 / 31 / 11$ & 0.0 & 0.0 & 0.0 & 0.0 & 0.0 & 0.0 & 0.0 & 0.0 & 0.0 \\
\hline \multicolumn{10}{|c|}{ Delaware R at Perry, KS (06890900) } \\
\hline $09 / 02 / 11$ & 0.0 & 0.0 & 0.0 & 0.0 & 100 & 0.0 & 0.0 & 0.0 & 0.0 \\
\hline 09/08/11 & 0.14 & 0.64 & 0 & 0 & 5.6 & 0.0 & 40 & 8.1 & 46 \\
\hline $09 / 12 / 11$ & 0.0 & 0.0 & 0.0 & 0.0 & 0.0 & 0.0 & 0.0 & 0.0 & 0.0 \\
\hline 09/20/11 & 0.0 & 0.0 & 0.0 & 0.0 & 0.0 & 0.0 & 0.0 & 0.0 & 0.0 \\
\hline $09 / 26 / 11$ & 0.0 & 0.0 & 0.0 & 0.0 & 0.0 & 0.0 & 0.0 & 0.0 & 0.0 \\
\hline $10 / 03 / 11$ & -- & -- & -- & -- & -- & -- & -- & -- & -- \\
\hline $10 / 05 / 11$ & -- & -- & -- & -- & -- & -- & -- & -- & -- \\
\hline $10 / 11 / 11$ & 100 & 0.0 & 0.0 & 0.0 & 0.0 & 0.0 & 0.0 & 0.0 & 0.0 \\
\hline $10 / 17 / 11$ & 11 & 0.0 & 73 & 0.0 & 0.0 & 0.0 & 17 & 0.0 & 0.0 \\
\hline $10 / 24 / 11$ & 22 & 0.0 & 78 & 0.0 & 0.0 & 0.0 & 0.0 & 0.0 & 0.0 \\
\hline $10 / 31 / 11$ & 100 & 0.0 & 0.0 & 0.0 & 0.0 & 0.0 & 0.0 & 0.0 & 0.0 \\
\hline
\end{tabular}


Appendix 3. Cyanobacterial community composition in samples collected from Kansas River tributary and main-stem sites during September and October 2011.-Continued

[cells/mL, cells per milliliter; \%, percent; nr, near; KS, Kansas; --, sample not collected; nm, analyte not measured but sample archived; R, River; Pl, Plaza]

\begin{tabular}{|c|c|c|c|c|c|c|c|c|c|c|}
\hline Date & $\begin{array}{l}\text { Cyanobacteria } \\
\text { abundance } \\
\text { (cells/mL) }\end{array}$ & $\begin{array}{r}\text { Anabaena } \\
\text { abundance } \\
\text { (cells/mL) }\end{array}$ & $\begin{array}{c}\text { Anabae- } \\
\text { nopsis } \\
\text { abundance } \\
\text { (cells/mL) }\end{array}$ & $\begin{array}{l}\text { Aphanizo- } \\
\text { menon } \\
\text { abundance } \\
\text { (cells/mL }\end{array}$ & $\begin{array}{l}\text { Aphano- } \\
\text { capsa } \\
\text { abundance } \\
\text { (cells/mL) }\end{array}$ & $\begin{array}{l}\text { Chroococ- } \\
\text { cus } \\
\text { abundance } \\
\text { (cells/mL) }\end{array}$ & $\begin{array}{l}\text { Cylindro- } \\
\text { spermopsis } \\
\text { abundance } \\
\text { (cells/mL) }\end{array}$ & $\begin{array}{l}\text { Microcystis } \\
\text { abundance } \\
\text { (cells/mL) }\end{array}$ & $\begin{array}{l}\text { Phormidium } \\
\text { abundance } \\
\text { (cells/mL) }\end{array}$ & $\begin{array}{c}\text { Pseudana- } \\
\text { baena } \\
\text { abundance } \\
\text { (cells } / \mathrm{mL} \text { ) }\end{array}$ \\
\hline \multicolumn{11}{|c|}{ Wakarusa R nr Lawrence, KS (06891500) } \\
\hline $09 / 02 / 11$ & 2,700 & 350 & 0.0 & 0.0 & 0.0 & 510 & 940 & 860 & 0.0 & 92 \\
\hline $09 / 08 / 11$ & 640 & 150 & 0.0 & 0.0 & 0.0 & 120 & 73 & 248 & 0.0 & 58 \\
\hline $09 / 12 / 11$ & $\mathrm{~nm}$ & $\mathrm{~nm}$ & $\mathrm{~nm}$ & $\mathrm{~nm}$ & $\mathrm{~nm}$ & $\mathrm{~nm}$ & $\mathrm{~nm}$ & $\mathrm{~nm}$ & $\mathrm{~nm}$ & $\mathrm{~nm}$ \\
\hline $09 / 20 / 11$ & $\mathrm{~nm}$ & $\mathrm{~nm}$ & $\mathrm{~nm}$ & $\mathrm{~nm}$ & $\mathrm{~nm}$ & $\mathrm{~nm}$ & $\mathrm{~nm}$ & $\mathrm{~nm}$ & $\mathrm{~nm}$ & $\mathrm{~nm}$ \\
\hline $09 / 26 / 11$ & $\mathrm{~nm}$ & $\mathrm{~nm}$ & $\mathrm{~nm}$ & $\mathrm{~nm}$ & $\mathrm{~nm}$ & $\mathrm{~nm}$ & $\mathrm{~nm}$ & $\mathrm{~nm}$ & $\mathrm{~nm}$ & $\mathrm{~nm}$ \\
\hline $10 / 03 / 11$ & $\mathrm{~nm}$ & $\mathrm{~nm}$ & $\mathrm{~nm}$ & $\mathrm{~nm}$ & $\mathrm{~nm}$ & $\mathrm{~nm}$ & $\mathrm{~nm}$ & $\mathrm{~nm}$ & $\mathrm{~nm}$ & $\mathrm{~nm}$ \\
\hline $10 / 05 / 11$ & -- & -- & -- & -- & -- & -- & -- & -- & -- & -- \\
\hline $10 / 11 / 11$ & -- & -- & -- & -- & -- & -- & -- & -- & -- & -- \\
\hline $10 / 17 / 11$ & -- & -- & -- & -- & -- & -- & -- & -- & -- & -- \\
\hline $10 / 24 / 11$ & -- & -- & -- & -- & -- & -- & -- & -- & -- & -- \\
\hline $10 / 31 / 11$ & -- & -- & -- & -- & -- & -- & -- & -- & -- & -- \\
\hline \multicolumn{11}{|c|}{ Kansas River main-stem sampling sites } \\
\hline \multicolumn{11}{|c|}{ Kansas R at Fort Riley, KS (06879100) } \\
\hline $09 / 02 / 11$ & 20,000 & 0.0 & 0.0 & 0.0 & 0.0 & 0.0 & 0.0 & 20,000 & 0.0 & 0.0 \\
\hline $09 / 08 / 11$ & 3,900 & 19 & 0.0 & 0.0 & 0.0 & 0.0 & 0.0 & 3,300 & 0.0 & 640 \\
\hline $09 / 12 / 11$ & $\mathrm{~nm}$ & $\mathrm{~nm}$ & $\mathrm{~nm}$ & $\mathrm{~nm}$ & $\mathrm{~nm}$ & $\mathrm{~nm}$ & $\mathrm{~nm}$ & $\mathrm{~nm}$ & $\mathrm{~nm}$ & $\mathrm{~nm}$ \\
\hline $09 / 20 / 11$ & $\mathrm{~nm}$ & $\mathrm{~nm}$ & $\mathrm{~nm}$ & $\mathrm{~nm}$ & $\mathrm{~nm}$ & $\mathrm{~nm}$ & $\mathrm{~nm}$ & $\mathrm{~nm}$ & $\mathrm{~nm}$ & $\mathrm{~nm}$ \\
\hline $09 / 26 / 11$ & $\mathrm{~nm}$ & $\mathrm{~nm}$ & $\mathrm{~nm}$ & $\mathrm{~nm}$ & $\mathrm{~nm}$ & $\mathrm{~nm}$ & $\mathrm{~nm}$ & $\mathrm{~nm}$ & $\mathrm{~nm}$ & $\mathrm{~nm}$ \\
\hline $10 / 03 / 11$ & $\mathrm{~nm}$ & $\mathrm{~nm}$ & $\mathrm{~nm}$ & $\mathrm{~nm}$ & $\mathrm{~nm}$ & $\mathrm{~nm}$ & $\mathrm{~nm}$ & $\mathrm{~nm}$ & $\mathrm{~nm}$ & $\mathrm{~nm}$ \\
\hline $10 / 05 / 11$ & -- & -- & -- & -- & -- & -- & -- & -- & -- & -- \\
\hline $10 / 11 / 11$ & -- & -- & -- & -- & -- & -- & -- & -- & -- & -- \\
\hline $10 / 17 / 11$ & -- & -- & -- & -- & -- & -- & -- & -- & -- & -- \\
\hline $10 / 24 / 11$ & -- & -- & -- & -- & -- & -- & -- & -- & -- & -- \\
\hline $10 / 31 / 11$ & -- & -- & -- & -- & -- & -- & -- & -- & -- & -- \\
\hline \multicolumn{11}{|c|}{ Kansas R at Manhattan, KS (06879820) } \\
\hline $09 / 02 / 11$ & 6,400 & 25 & 0.0 & 0.0 & 0.0 & 0.0 & 0.0 & 6,200 & 0.0 & 260 \\
\hline $09 / 08 / 11$ & 4,700 & 47 & 0.0 & 0.0 & 0.0 & 320 & 0.0 & 4,400 & 0.0 & 0.0 \\
\hline $09 / 12 / 11$ & $\mathrm{~nm}$ & $\mathrm{~nm}$ & $\mathrm{~nm}$ & $\mathrm{~nm}$ & $\mathrm{~nm}$ & $\mathrm{~nm}$ & $\mathrm{~nm}$ & $\mathrm{~nm}$ & $\mathrm{~nm}$ & $\mathrm{~nm}$ \\
\hline $09 / 20 / 11$ & $\mathrm{~nm}$ & $\mathrm{~nm}$ & $\mathrm{~nm}$ & $\mathrm{~nm}$ & $\mathrm{~nm}$ & $\mathrm{~nm}$ & $\mathrm{~nm}$ & $\mathrm{~nm}$ & $\mathrm{~nm}$ & $\mathrm{~nm}$ \\
\hline $09 / 26 / 11$ & $\mathrm{~nm}$ & $\mathrm{~nm}$ & $\mathrm{~nm}$ & $\mathrm{~nm}$ & $\mathrm{~nm}$ & $\mathrm{~nm}$ & $\mathrm{~nm}$ & $\mathrm{~nm}$ & $\mathrm{~nm}$ & $\mathrm{~nm}$ \\
\hline $10 / 03 / 11$ & $\mathrm{~nm}$ & $\mathrm{~nm}$ & $\mathrm{~nm}$ & $\mathrm{~nm}$ & $\mathrm{~nm}$ & $\mathrm{~nm}$ & $\mathrm{~nm}$ & $\mathrm{~nm}$ & $\mathrm{~nm}$ & $\mathrm{~nm}$ \\
\hline $10 / 05 / 11$ & -- & -- & -- & -- & -- & -- & -- & -- & -- & -- \\
\hline $10 / 11 / 11$ & -- & -- & -- & -- & -- & -- & -- & -- & -- & -- \\
\hline $10 / 17 / 11$ & -- & -- & -- & -- & -- & -- & -- & -- & -- & -- \\
\hline $10 / 24 / 11$ & -- & -- & -- & -- & -- & -- & -- & -- & -- & -- \\
\hline $10 / 31 / 11$ & -- & -- & -- & -- & -- & -- & -- & -- & -- & -- \\
\hline
\end{tabular}


Appendix 3. Cyanobacterial community composition in samples collected from Kansas River tributary and main-stem sites during September and October 2011.-Continued

[cells/mL, cells per milliliter; \%, percent; nr, near; KS, Kansas; --, sample not collected; nm, analyte not measured but sample archived; R, River; Pl, Plaza]

\begin{tabular}{|c|c|c|c|c|c|c|c|c|c|}
\hline Date & $\begin{array}{c}\text { Anabaena } \\
\text { relative } \\
\text { abundance } \\
(\%)\end{array}$ & $\begin{array}{c}\text { Anabaenopsis } \\
\text { relative } \\
\text { abundance } \\
(\%)\end{array}$ & $\begin{array}{l}\text { Aphanizo- } \\
\text { menon } \\
\text { relative } \\
\text { abundance } \\
(\%)\end{array}$ & $\begin{array}{c}\text { Aphanocapsa } \\
\text { relative } \\
\text { abundance } \\
(\%)\end{array}$ & $\begin{array}{c}\text { Chroococcus } \\
\text { relative } \\
\text { abundance } \\
(\%)\end{array}$ & $\begin{array}{l}\text { Cylindrosper- } \\
\text { mopsis } \\
\text { relative } \\
\text { abundance } \\
(\%)\end{array}$ & $\begin{array}{c}\text { Microcystis } \\
\text { relative } \\
\text { abundance } \\
(\%)\end{array}$ & $\begin{array}{c}\text { Phormidium } \\
\text { relative } \\
\text { abundance } \\
(\%)\end{array}$ & $\begin{array}{c}\text { Pseudanbaena } \\
\text { relative } \\
\text { abundance } \\
(\%)\end{array}$ \\
\hline \multicolumn{10}{|c|}{ Wakarusa R nr Lawrence, KS (06891500) } \\
\hline $09 / 02 / 11$ & 13 & 0.0 & 0.0 & 0.0 & 19 & 34 & 31 & 0.0 & 3.3 \\
\hline $09 / 08 / 11$ & 23 & 0.0 & 0.0 & 0.0 & 18 & 11 & 38 & 0.0 & 9.0 \\
\hline $09 / 12 / 11$ & $\mathrm{~nm}$ & $\mathrm{~nm}$ & $\mathrm{~nm}$ & $\mathrm{~nm}$ & $\mathrm{~nm}$ & $\mathrm{~nm}$ & $\mathrm{~nm}$ & $\mathrm{~nm}$ & $\mathrm{~nm}$ \\
\hline $09 / 20 / 11$ & $\mathrm{~nm}$ & $\mathrm{~nm}$ & $\mathrm{~nm}$ & $\mathrm{~nm}$ & $\mathrm{~nm}$ & $\mathrm{~nm}$ & $\mathrm{~nm}$ & $\mathrm{~nm}$ & $\mathrm{~nm}$ \\
\hline $09 / 26 / 11$ & $\mathrm{~nm}$ & $\mathrm{~nm}$ & $\mathrm{~nm}$ & $\mathrm{~nm}$ & $\mathrm{~nm}$ & $\mathrm{~nm}$ & $\mathrm{~nm}$ & $\mathrm{~nm}$ & $\mathrm{~nm}$ \\
\hline $10 / 03 / 11$ & $\mathrm{~nm}$ & $\mathrm{~nm}$ & $\mathrm{~nm}$ & $\mathrm{~nm}$ & $\mathrm{~nm}$ & $\mathrm{~nm}$ & $\mathrm{~nm}$ & $\mathrm{~nm}$ & $\mathrm{~nm}$ \\
\hline $10 / 05 / 11$ & -- & -- & -- & -- & -- & -- & -- & -- & -- \\
\hline $10 / 11 / 11$ & -- & -- & -- & -- & -- & -- & -- & -- & -- \\
\hline $10 / 17 / 11$ & -- & -- & -- & -- & -- & -- & -- & -- & -- \\
\hline $10 / 24 / 11$ & -- & -- & -- & -- & -- & -- & -- & -- & -- \\
\hline $10 / 31 / 11$ & -- & -- & -- & -- & -- & -- & -- & -- & -- \\
\hline \multicolumn{10}{|c|}{ Kansas River main-stem sampling sites } \\
\hline \multicolumn{10}{|c|}{ Kansas $\mathrm{R}$ at Fort Riley, KS (06879100) } \\
\hline $09 / 02 / 11$ & 0.0 & 0.0 & 0.0 & 0.0 & 0.0 & 0.0 & 100 & 0.0 & 0.0 \\
\hline $09 / 08 / 11$ & 0.48 & 0.0 & 0.0 & 0.0 & 0.0 & 0.0 & 83 & 0.0 & 16 \\
\hline $09 / 12 / 11$ & $\mathrm{~nm}$ & $\mathrm{~nm}$ & $\mathrm{~nm}$ & $\mathrm{~nm}$ & $\mathrm{~nm}$ & $\mathrm{~nm}$ & $\mathrm{~nm}$ & $\mathrm{~nm}$ & $\mathrm{~nm}$ \\
\hline $09 / 20 / 11$ & $\mathrm{~nm}$ & $\mathrm{~nm}$ & $\mathrm{~nm}$ & $\mathrm{~nm}$ & $\mathrm{~nm}$ & $\mathrm{~nm}$ & $\mathrm{~nm}$ & $\mathrm{~nm}$ & $\mathrm{~nm}$ \\
\hline $09 / 26 / 11$ & $\mathrm{~nm}$ & $\mathrm{~nm}$ & $\mathrm{~nm}$ & $\mathrm{~nm}$ & $\mathrm{~nm}$ & $\mathrm{~nm}$ & $\mathrm{~nm}$ & $\mathrm{~nm}$ & $\mathrm{~nm}$ \\
\hline $10 / 03 / 11$ & $\mathrm{~nm}$ & $\mathrm{~nm}$ & $\mathrm{~nm}$ & $\mathrm{~nm}$ & $\mathrm{~nm}$ & $\mathrm{~nm}$ & $\mathrm{~nm}$ & $\mathrm{~nm}$ & $\mathrm{~nm}$ \\
\hline $10 / 05 / 11$ & -- & -- & -- & -- & -- & -- & -- & -- & -- \\
\hline $10 / 11 / 11$ & -- & -- & -- & -- & -- & -- & -- & -- & -- \\
\hline $10 / 17 / 11$ & -- & -- & -- & -- & -- & -- & -- & -- & -- \\
\hline $10 / 24 / 11$ & -- & -- & -- & -- & -- & -- & -- & -- & -- \\
\hline $10 / 31 / 11$ & -- & -- & -- & -- & -- & -- & -- & -- & -- \\
\hline \multicolumn{10}{|c|}{ Kansas R at Manhattan, KS (06879820) } \\
\hline $09 / 02 / 11$ & 0.38 & 0.0 & 0.0 & 0.0 & 0.0 & 0.0 & 96 & 0.0 & 3.9 \\
\hline 09/08/11 & 0.99 & 0.0 & 0.0 & 0.0 & 6.7 & 0.0 & 92 & 0.0 & 0.0 \\
\hline $09 / 12 / 11$ & $\mathrm{~nm}$ & $\mathrm{~nm}$ & $\mathrm{~nm}$ & $\mathrm{~nm}$ & $\mathrm{~nm}$ & $\mathrm{~nm}$ & $\mathrm{~nm}$ & $\mathrm{~nm}$ & $\mathrm{~nm}$ \\
\hline 09/20/11 & $\mathrm{nm}$ & $\mathrm{nm}$ & $\mathrm{nm}$ & $\mathrm{nm}$ & $\mathrm{nm}$ & $\mathrm{nm}$ & $\mathrm{nm}$ & $\mathrm{nm}$ & $\mathrm{nm}$ \\
\hline $09 / 26 / 11$ & $\mathrm{~nm}$ & $\mathrm{~nm}$ & $\mathrm{~nm}$ & $\mathrm{~nm}$ & $\mathrm{~nm}$ & $\mathrm{~nm}$ & $\mathrm{~nm}$ & $\mathrm{~nm}$ & $\mathrm{~nm}$ \\
\hline $10 / 03 / 11$ & $\mathrm{~nm}$ & $\mathrm{~nm}$ & $\mathrm{~nm}$ & $\mathrm{~nm}$ & $\mathrm{~nm}$ & $\mathrm{~nm}$ & $\mathrm{~nm}$ & $\mathrm{~nm}$ & $\mathrm{~nm}$ \\
\hline $10 / 05 / 11$ & -- & -- & -- & -- & -- & -- & -- & -- & -- \\
\hline $10 / 11 / 11$ & -- & -- & -- & -- & -- & -- & -- & -- & -- \\
\hline $10 / 17 / 11$ & -- & -- & -- & -- & -- & -- & -- & -- & -- \\
\hline $10 / 24 / 11$ & -- & -- & -- & -- & -- & -- & -- & -- & -- \\
\hline $10 / 31 / 11$ & -- & -- & -- & -- & -- & -- & -- & -- & -- \\
\hline
\end{tabular}


Appendix 3. Cyanobacterial community composition in samples collected from Kansas River tributary and main-stem sites during September and October 2011.-Continued

[cells/mL, cells per milliliter; \%, percent; nr, near; KS, Kansas; --, sample not collected; nm, analyte not measured but sample archived; R, River; Pl, Plaza]

\begin{tabular}{|c|c|c|c|c|c|c|c|c|c|c|}
\hline Date & $\begin{array}{l}\text { Cyanobacteria } \\
\text { abundance } \\
\text { (cells/mL) }\end{array}$ & $\begin{array}{c}\text { Anabaena } \\
\text { abundance } \\
\text { (cells/mL) }\end{array}$ & $\begin{array}{l}\text { Anabae- } \\
\text { nopsis } \\
\text { abundance } \\
\text { (cells/mL) }\end{array}$ & $\begin{array}{l}\text { Aphanizo- } \\
\text { menon } \\
\text { abundance } \\
\text { (cells/mL }\end{array}$ & $\begin{array}{l}\text { Aphano- } \\
\text { capsa } \\
\text { abundance } \\
\text { (cells/mL) }\end{array}$ & $\begin{array}{l}\text { Chroococ- } \\
\text { cus } \\
\text { abundance } \\
\text { (cells/mL) }\end{array}$ & $\begin{array}{l}\text { Cylindro- } \\
\text { spermopsis } \\
\text { abundance } \\
\text { (cells/mL) }\end{array}$ & $\begin{array}{l}\text { Microcystis } \\
\text { abundance } \\
\text { (cells/mL) }\end{array}$ & $\begin{array}{l}\text { Phormidium } \\
\text { abundance } \\
\text { (cells/mL) }\end{array}$ & $\begin{array}{c}\text { Pseudana- } \\
\text { baena } \\
\text { abundance } \\
\text { (cells/mL) }\end{array}$ \\
\hline \multicolumn{11}{|c|}{ Kansas R at Wamego, KS (06887500) } \\
\hline $09 / 02 / 11$ & 3,400 & 68 & 0.0 & 0.0 & 0.0 & 0.0 & 0.0 & 3,400 & 0.0 & 0.0 \\
\hline 09/08/11 & 550 & 0.0 & 0.0 & 0.0 & 0.0 & 0.0 & 0.0 & 550 & 0.0 & 0.0 \\
\hline 09/12/11 & 0.0 & 0.0 & 0.0 & 0.0 & 0.0 & 0.0 & 0.0 & 0.0 & 0.0 & 0.0 \\
\hline $09 / 20 / 11$ & 530 & 530 & 0.0 & 0.0 & 0.0 & 0.0 & 0.0 & 0.0 & 0.0 & 0.0 \\
\hline $09 / 26 / 11$ & 710 & 0.0 & 0.0 & 0.0 & 0.0 & 0.0 & 0.0 & 710 & 0.0 & 0.0 \\
\hline $10 / 03 / 11$ & 510 & 510 & 0.0 & 0.0 & 0.0 & 0.0 & 0.0 & 0.0 & 0.0 & 0.0 \\
\hline $10 / 05 / 11$ & 0.0 & 0.0 & 0.0 & 0.0 & 0.0 & 0.0 & 0.0 & 0.0 & 0.0 & 0.0 \\
\hline $10 / 11 / 11$ & $\mathrm{~nm}$ & $\mathrm{~nm}$ & $\mathrm{~nm}$ & $\mathrm{~nm}$ & $\mathrm{~nm}$ & $\mathrm{~nm}$ & $\mathrm{~nm}$ & $\mathrm{~nm}$ & $\mathrm{~nm}$ & $\mathrm{~nm}$ \\
\hline $10 / 17 / 11$ & $\mathrm{~nm}$ & $\mathrm{~nm}$ & $\mathrm{~nm}$ & $\mathrm{~nm}$ & $\mathrm{~nm}$ & $\mathrm{~nm}$ & $\mathrm{~nm}$ & $\mathrm{~nm}$ & $\mathrm{~nm}$ & $\mathrm{~nm}$ \\
\hline $10 / 24 / 11$ & $\mathrm{~nm}$ & $\mathrm{~nm}$ & $\mathrm{~nm}$ & $\mathrm{~nm}$ & $\mathrm{~nm}$ & $\mathrm{~nm}$ & $\mathrm{~nm}$ & $\mathrm{~nm}$ & $\mathrm{~nm}$ & $\mathrm{~nm}$ \\
\hline $10 / 31 / 11$ & $\mathrm{~nm}$ & $\mathrm{~nm}$ & $\mathrm{~nm}$ & $\mathrm{~nm}$ & $\mathrm{~nm}$ & $\mathrm{~nm}$ & $\mathrm{~nm}$ & $\mathrm{~nm}$ & $\mathrm{~nm}$ & $\mathrm{~nm}$ \\
\hline \multicolumn{11}{|c|}{ Kansas R nr Belvue, KS (06888350) } \\
\hline $09 / 02 / 11$ & 23,000 & 0.0 & 0.0 & 0.0 & 0.0 & 1,700 & 0.0 & 20,000 & 0.0 & 960 \\
\hline 09/08/11 & -- & -- & -- & -- & -- & -- & -- & -- & -- & -- \\
\hline $09 / 12 / 11$ & -- & -- & -- & -- & -- & -- & -- & -- & -- & -- \\
\hline $09 / 20 / 11$ & -- & -- & -- & -- & -- & -- & -- & -- & -- & -- \\
\hline $09 / 26 / 11$ & -- & -- & -- & -- & -- & -- & -- & -- & -- & -- \\
\hline $10 / 03 / 11$ & -- & -- & -- & -- & -- & -- & -- & -- & -- & -- \\
\hline $10 / 05 / 11$ & -- & -- & -- & -- & -- & -- & -- & -- & -- & -- \\
\hline $10 / 11 / 11$ & -- & -- & -- & -- & -- & -- & -- & -- & -- & -- \\
\hline $10 / 17 / 11$ & -- & -- & -- & -- & -- & -- & -- & -- & -- & -- \\
\hline $10 / 24 / 11$ & -- & -- & -- & -- & -- & -- & -- & -- & -- & -- \\
\hline $10 / 31 / 11$ & -- & -- & -- & -- & -- & -- & -- & -- & -- & -- \\
\hline \multicolumn{11}{|c|}{ Kansas R at Topeka, KS (06889000) } \\
\hline $09 / 02 / 11$ & 3,400 & 0.0 & 0.0 & 0.0 & 0.0 & 850 & 0.0 & 2,800 & 0.0 & 0.0 \\
\hline 09/08/11 & 17,000 & 0.0 & 0.0 & 0.0 & 0.0 & 210 & 0.0 & 17,000 & 0.0 & 0.0 \\
\hline $09 / 12 / 11$ & $\mathrm{~nm}$ & $\mathrm{~nm}$ & $\mathrm{~nm}$ & $\mathrm{~nm}$ & $\mathrm{~nm}$ & $\mathrm{~nm}$ & $\mathrm{~nm}$ & $\mathrm{~nm}$ & $\mathrm{~nm}$ & $\mathrm{~nm}$ \\
\hline 09/20/11 & 200 & 0.0 & 0.0 & 200 & 0.0 & 0.0 & 0.0 & 0.0 & 0.0 & 0.0 \\
\hline $09 / 26 / 11$ & 0.0 & 0.0 & 0.0 & 0.0 & 0.0 & 0.0 & 0.0 & 0.0 & 0.0 & 0.0 \\
\hline $10 / 03 / 11$ & 1,100 & 1,100 & 0.0 & 0.0 & 0.0 & 0.0 & 0.0 & 0.0 & 0.0 & 0.0 \\
\hline $10 / 05 / 11$ & -- & -- & -- & -- & -- & -- & -- & -- & -- & -- \\
\hline 10/11/11 & $\mathrm{nm}$ & $\mathrm{nm}$ & $\mathrm{nm}$ & $\mathrm{nm}$ & $\mathrm{nm}$ & $\mathrm{nm}$ & $\mathrm{nm}$ & $\mathrm{nm}$ & $\mathrm{nm}$ & $\mathrm{nm}$ \\
\hline $10 / 17 / 11$ & $\mathrm{~nm}$ & $\mathrm{~nm}$ & $\mathrm{~nm}$ & $\mathrm{~nm}$ & $\mathrm{~nm}$ & $\mathrm{~nm}$ & $\mathrm{~nm}$ & $\mathrm{~nm}$ & $\mathrm{~nm}$ & $\mathrm{~nm}$ \\
\hline $10 / 24 / 11$ & $\mathrm{~nm}$ & $\mathrm{~nm}$ & $\mathrm{~nm}$ & $\mathrm{~nm}$ & $\mathrm{~nm}$ & $\mathrm{~nm}$ & $\mathrm{~nm}$ & $\mathrm{~nm}$ & $\mathrm{~nm}$ & $\mathrm{~nm}$ \\
\hline $10 / 31 / 11$ & $\mathrm{~nm}$ & $\mathrm{~nm}$ & $\mathrm{~nm}$ & $\mathrm{~nm}$ & $\mathrm{~nm}$ & $\mathrm{~nm}$ & $\mathrm{~nm}$ & $\mathrm{~nm}$ & $\mathrm{~nm}$ & $\mathrm{~nm}$ \\
\hline
\end{tabular}


Appendix 3. Cyanobacterial community composition in samples collected from Kansas River tributary and main-stem sites during September and October 2011.-Continued

[cells/mL, cells per milliliter; \%, percent; nr, near; KS, Kansas; --, sample not collected; nm, analyte not measured but sample archived; R, River; Pl, Plaza]

\begin{tabular}{|c|c|c|c|c|c|c|c|c|c|}
\hline Date & $\begin{array}{c}\text { Anabaena } \\
\text { relative } \\
\text { abundance } \\
(\%)\end{array}$ & $\begin{array}{c}\text { Anabaenopsis } \\
\text { relative } \\
\text { abundance } \\
(\%)\end{array}$ & $\begin{array}{l}\text { Aphanizo- } \\
\text { menon } \\
\text { relative } \\
\text { abundance } \\
(\%)\end{array}$ & $\begin{array}{c}\text { Aphanocapsa } \\
\text { relative } \\
\text { abundance } \\
(\%)\end{array}$ & $\begin{array}{c}\text { Chroococcus } \\
\text { relative } \\
\text { abundance } \\
(\%)\end{array}$ & $\begin{array}{l}\text { Cylindrosper- } \\
\text { mopsis } \\
\text { relative } \\
\text { abundance } \\
(\%)\end{array}$ & $\begin{array}{c}\text { Microcystis } \\
\text { relative } \\
\text { abundance } \\
(\%)\end{array}$ & $\begin{array}{c}\text { Phormidium } \\
\text { relative } \\
\text { abundance } \\
(\%)\end{array}$ & $\begin{array}{c}\text { Pseudanbaena } \\
\text { relative } \\
\text { abundance } \\
(\%)\end{array}$ \\
\hline \multicolumn{10}{|c|}{ Kansas $\mathrm{R}$ at Wamego, KS (06887500) } \\
\hline $09 / 02 / 11$ & 2.0 & 0.0 & 0.0 & 0.0 & 0.0 & 0.0 & 98 & 0.0 & 0.0 \\
\hline 09/08/11 & 0.0 & 0.0 & 0.0 & 0.0 & 0.0 & 0.0 & 100 & 0.0 & 0.0 \\
\hline $09 / 12 / 11$ & 0.0 & 0.0 & 0.0 & 0.0 & 0.0 & 0.0 & 0.0 & 0.0 & 0.0 \\
\hline 09/20/11 & 100 & 0.0 & 0.0 & 0.0 & 0.0 & 0.0 & 0.0 & 0.0 & 0.0 \\
\hline $09 / 26 / 11$ & 0.0 & 0.0 & 0.0 & 0.0 & 0.0 & 0.0 & 100 & 0.0 & 0.0 \\
\hline $10 / 03 / 11$ & 100 & 0.0 & 0.0 & 0.0 & 0.0 & 0.0 & 0.0 & 0.0 & 0.0 \\
\hline $10 / 05 / 11$ & 0.0 & 0.0 & 0.0 & 0.0 & 0.0 & 0.0 & 0.0 & 0.0 & 0.0 \\
\hline $10 / 11 / 11$ & $\mathrm{~nm}$ & $\mathrm{~nm}$ & $\mathrm{~nm}$ & $\mathrm{~nm}$ & $\mathrm{~nm}$ & $\mathrm{~nm}$ & $\mathrm{~nm}$ & $\mathrm{~nm}$ & $\mathrm{~nm}$ \\
\hline $10 / 17 / 11$ & $\mathrm{~nm}$ & $\mathrm{~nm}$ & $\mathrm{~nm}$ & $\mathrm{~nm}$ & $\mathrm{~nm}$ & $\mathrm{~nm}$ & $\mathrm{~nm}$ & $\mathrm{~nm}$ & $\mathrm{~nm}$ \\
\hline $10 / 24 / 11$ & $\mathrm{~nm}$ & $\mathrm{~nm}$ & $\mathrm{~nm}$ & $\mathrm{~nm}$ & $\mathrm{~nm}$ & $\mathrm{~nm}$ & $\mathrm{~nm}$ & $\mathrm{~nm}$ & $\mathrm{~nm}$ \\
\hline $10 / 31 / 11$ & $\mathrm{~nm}$ & $\mathrm{~nm}$ & $\mathrm{~nm}$ & $\mathrm{~nm}$ & $\mathrm{~nm}$ & $\mathrm{~nm}$ & $\mathrm{~nm}$ & $\mathrm{~nm}$ & $\mathrm{~nm}$ \\
\hline \multicolumn{10}{|c|}{ Kansas R nr Belvue, KS (06888350) } \\
\hline $09 / 02 / 11$ & 0.0 & 0.0 & 0.0 & 0.0 & 7.4 & 0.0 & 88 & 0.0 & 4.1 \\
\hline 09/08/11 & -- & -- & -- & -- & -- & -- & -- & -- & -- \\
\hline $09 / 12 / 11$ & -- & -- & -- & -- & -- & -- & -- & -- & -- \\
\hline 09/20/11 & -- & -- & -- & -- & -- & -- & -- & -- & -- \\
\hline $09 / 26 / 11$ & -- & -- & -- & -- & -- & -- & -- & -- & -- \\
\hline $10 / 03 / 11$ & -- & -- & -- & -- & -- & -- & -- & -- & -- \\
\hline $10 / 05 / 11$ & -- & -- & -- & -- & -- & -- & -- & -- & -- \\
\hline $10 / 11 / 11$ & -- & -- & -- & -- & -- & -- & -- & -- & -- \\
\hline $10 / 17 / 11$ & -- & -- & -- & -- & -- & -- & -- & -- & -- \\
\hline $10 / 24 / 11$ & -- & -- & -- & -- & -- & -- & -- & -- & -- \\
\hline $10 / 31 / 11$ & -- & -- & -- & -- & -- & -- & -- & -- & -- \\
\hline \multicolumn{10}{|c|}{ Kansas R at Topeka, KS (06889000) } \\
\hline $09 / 02 / 11$ & 0.0 & 0.0 & 0.0 & 0.0 & 17 & 0.0 & 83 & 0.0 & 0.0 \\
\hline $09 / 08 / 11$ & 0.0 & 0.0 & 0.0 & 0.0 & 1.2 & 0.0 & 99 & 0.0 & 0.0 \\
\hline $09 / 12 / 11$ & $\mathrm{~nm}$ & $\mathrm{~nm}$ & $\mathrm{~nm}$ & $\mathrm{~nm}$ & $\mathrm{~nm}$ & $\mathrm{~nm}$ & $\mathrm{~nm}$ & $\mathrm{~nm}$ & $\mathrm{~nm}$ \\
\hline $09 / 20 / 11$ & 0.0 & 0.0 & 100 & 0.0 & 0.0 & 0.0 & 0.0 & 0.0 & 0.0 \\
\hline $09 / 26 / 11$ & 0.0 & 0.0 & 0.0 & 0.0 & 0.0 & 0.0 & 0.0 & 0.0 & 0.0 \\
\hline $10 / 03 / 11$ & 100 & 0.0 & 0.0 & 0.0 & 0.0 & 0.0 & 0.0 & 0.0 & 0.0 \\
\hline $10 / 05 / 11$ & -- & -- & -- & -- & -- & -- & -- & -- & -- \\
\hline $10 / 11 / 11$ & $\mathrm{~nm}$ & $\mathrm{~nm}$ & $\mathrm{~nm}$ & $\mathrm{~nm}$ & $\mathrm{~nm}$ & $\mathrm{~nm}$ & $\mathrm{~nm}$ & $\mathrm{~nm}$ & $\mathrm{~nm}$ \\
\hline $10 / 17 / 11$ & $\mathrm{~nm}$ & $\mathrm{~nm}$ & $\mathrm{~nm}$ & $\mathrm{~nm}$ & $\mathrm{~nm}$ & $\mathrm{~nm}$ & $\mathrm{~nm}$ & $\mathrm{~nm}$ & $\mathrm{~nm}$ \\
\hline $10 / 24 / 11$ & $\mathrm{~nm}$ & $\mathrm{~nm}$ & $\mathrm{~nm}$ & $\mathrm{~nm}$ & $\mathrm{~nm}$ & $\mathrm{~nm}$ & $\mathrm{~nm}$ & $\mathrm{~nm}$ & $\mathrm{~nm}$ \\
\hline $10 / 31 / 11$ & $\mathrm{~nm}$ & $\mathrm{~nm}$ & $\mathrm{~nm}$ & $\mathrm{~nm}$ & $\mathrm{~nm}$ & $\mathrm{~nm}$ & $\mathrm{~nm}$ & $\mathrm{~nm}$ & $\mathrm{~nm}$ \\
\hline
\end{tabular}


Appendix 3. Cyanobacterial community composition in samples collected from Kansas River tributary and main-stem sites during September and October 2011.-Continued

[cells/mL, cells per milliliter; \%, percent; nr, near; KS, Kansas; --, sample not collected; nm, analyte not measured but sample archived; R, River; Pl, Plaza]

\begin{tabular}{|c|c|c|c|c|c|c|c|c|c|c|}
\hline Date & $\begin{array}{c}\text { Cyanobacteria } \\
\text { abundance } \\
\text { (cells/mL) }\end{array}$ & $\begin{array}{c}\text { Anabaena } \\
\text { abundance } \\
\text { (cells/mL) }\end{array}$ & $\begin{array}{l}\text { Anabae- } \\
\text { nopsis } \\
\text { abundance } \\
\text { (cells/mL) }\end{array}$ & $\begin{array}{l}\text { Aphanizo- } \\
\text { menon } \\
\text { abundance } \\
\text { (cells/mL }\end{array}$ & $\begin{array}{l}\text { Aphano- } \\
\text { capsa } \\
\text { abundance } \\
\text { (cells/mL) }\end{array}$ & $\begin{array}{c}\text { Chroococ- } \\
\text { cus } \\
\text { abundance } \\
\text { (cells/mL) }\end{array}$ & $\begin{array}{l}\text { Cylindro- } \\
\text { spermopsis } \\
\text { abundance } \\
\text { (cells/mL) }\end{array}$ & $\begin{array}{l}\text { Microcystis } \\
\text { abundance } \\
\text { (cells/mL) }\end{array}$ & $\begin{array}{l}\text { Phormidium } \\
\text { abundance } \\
\text { (cells/mL) }\end{array}$ & $\begin{array}{c}\text { Pseudana- } \\
\text { baena } \\
\text { abundance } \\
\text { (cells/mL) }\end{array}$ \\
\hline \multicolumn{11}{|c|}{ Kansas R at Lecompton, KS (06891000) } \\
\hline $09 / 02 / 11$ & 950 & 0.0 & 0.0 & 0.0 & 0.0 & 950 & 0.0 & 0.0 & 0.0 & 0.0 \\
\hline 09/08/11 & 10,000 & 350 & 0.0 & 0.0 & 0.0 & 0.0 & 0.0 & 8,200 & 1,200 & 210 \\
\hline $09 / 12 / 11$ & 5,700 & 0.0 & 0.0 & 0.0 & 0.0 & 0.0 & 0.0 & 5,700 & 0.0 & 0.0 \\
\hline 09/20/11 & 390 & 390 & 0.0 & 0.0 & 0.0 & 0.0 & 0.0 & 0.0 & 0.0 & 0.0 \\
\hline 09/26/11 & 0.0 & 0.0 & 0.0 & 0.0 & 0.0 & 0.0 & 0.0 & 0.0 & 0.0 & 0.0 \\
\hline $10 / 03 / 11$ & 1,000 & 1000 & 0.0 & 0.0 & 0.0 & 0.0 & 0.0 & 0.0 & 0.0 & 0.0 \\
\hline $10 / 05 / 11$ & 940 & 850 & 0.0 & 0.0 & 0.0 & 0.0 & 0.0 & 84 & 0.0 & 0.0 \\
\hline $10 / 11 / 11$ & -- & -- & -- & -- & -- & -- & -- & -- & -- & -- \\
\hline $10 / 17 / 11$ & -- & -- & -- & -- & -- & -- & -- & -- & -- & -- \\
\hline $10 / 24 / 11$ & -- & -- & -- & -- & -- & -- & -- & -- & -- & -- \\
\hline $10 / 31 / 11$ & -- & -- & -- & -- & -- & -- & -- & -- & -- & -- \\
\hline \multicolumn{11}{|c|}{ Kansas R at Lawrence, KS (06891080) } \\
\hline $09 / 02 / 11$ & -- & -- & -- & -- & -- & -- & -- & -- & -- & -- \\
\hline 09/08/11 & -- & -- & -- & -- & -- & -- & -- & -- & -- & -- \\
\hline $09 / 12 / 11$ & -- & -- & -- & -- & -- & -- & -- & -- & -- & -- \\
\hline $09 / 20 / 11$ & 0.0 & 0.0 & 0.0 & 0.0 & 0.0 & 0.0 & 0.0 & 0.0 & 0.0 & 0.0 \\
\hline $09 / 26 / 11$ & 0.0 & 0.0 & 0.0 & 0.0 & 0.0 & 0.0 & 0.0 & 0.0 & 0.0 & 0.0 \\
\hline $10 / 03 / 11$ & 2,100 & 2100 & 0.0 & 0.0 & 0.0 & 0.0 & 0.0 & 0.0 & 0.0 & 0.0 \\
\hline $10 / 05 / 11$ & -- & -- & -- & -- & -- & -- & -- & -- & -- & -- \\
\hline $10 / 11 / 11$ & -- & -- & -- & -- & -- & -- & -- & -- & -- & -- \\
\hline $10 / 17 / 11$ & -- & -- & -- & -- & -- & -- & -- & -- & -- & -- \\
\hline $10 / 24 / 11$ & -- & -- & -- & -- & -- & -- & -- & -- & -- & -- \\
\hline $10 / 31 / 11$ & -- & -- & -- & -- & -- & -- & -- & -- & -- & -- \\
\hline \multicolumn{11}{|c|}{ Kansas R at Desoto, KS (06892350) } \\
\hline $09 / 02 / 11$ & 2,400 & 0.0 & 0.0 & 0.0 & 0.0 & 1,200 & 0.0 & 590 & 0.0 & 580 \\
\hline 09/08/11 & 2,300 & 0.0 & 0.0 & 0.0 & 0.0 & 0.0 & 0.0 & 1,900 & 330 & 0.0 \\
\hline $09 / 12 / 11$ & 0.0 & 0.0 & 0.0 & 0.0 & 0.0 & 0.0 & 0.0 & 0.0 & 0.0 & 0.0 \\
\hline $09 / 20 / 11$ & 0.0 & 0.0 & 0.0 & 0.0 & 0.0 & 0.0 & 0.0 & 0.0 & 0.0 & 0.0 \\
\hline 09/26/11 & 0.0 & 0.0 & 0.0 & 0.0 & 0.0 & 0.0 & 0.0 & 0.0 & 0.0 & 0.0 \\
\hline $10 / 03 / 11$ & 13 & 13 & 0.0 & 0.0 & 0.0 & 0.0 & 0.0 & 0.0 & 0.0 & 0.0 \\
\hline $10 / 05 / 11$ & -- & -- & -- & -- & -- & -- & -- & -- & -- & -- \\
\hline $10 / 11 / 11$ & 0.0 & 0.0 & 0.0 & 0.0 & 0.0 & 0.0 & 0.0 & 0.0 & 0.0 & 0.0 \\
\hline $10 / 17 / 11$ & 0.0 & 0.0 & 0.0 & 0.0 & 0.0 & 0.0 & 0.0 & 0.0 & 0.0 & 0.0 \\
\hline $10 / 24 / 11$ & 0.0 & 0.0 & 0.0 & 0.0 & 0.0 & 0.0 & 0.0 & 0.0 & 0.0 & 0.0 \\
\hline $10 / 31 / 11$ & 670 & 0.0 & 0.0 & 670 & 0.0 & 0.0 & 0.0 & 0.0 & 0.0 & 0.0 \\
\hline
\end{tabular}


Appendix 3. Cyanobacterial community composition in samples collected from Kansas River tributary and main-stem sites during September and October 2011.-Continued

[cells/mL, cells per milliliter; \%, percent; nr, near; KS, Kansas; --, sample not collected; nm, analyte not measured but sample archived; R, River; Pl, Plaza]

\begin{tabular}{|c|c|c|c|c|c|c|c|c|c|}
\hline Date & $\begin{array}{c}\text { Anabaena } \\
\text { relative } \\
\text { abundance } \\
(\%)\end{array}$ & $\begin{array}{l}\text { Anabaenopsis } \\
\text { relative } \\
\text { abundance } \\
(\%)\end{array}$ & $\begin{array}{c}\text { Aphanizo- } \\
\text { menon } \\
\text { relative } \\
\text { abundance } \\
(\%)\end{array}$ & $\begin{array}{l}\text { Aphanocapsa } \\
\text { relative } \\
\text { abundance } \\
(\%)\end{array}$ & $\begin{array}{c}\text { Chroococcus } \\
\text { relative } \\
\text { abundance } \\
(\%)\end{array}$ & $\begin{array}{c}\text { Cylindrosper- } \\
\text { mopsis } \\
\text { relative } \\
\text { abundance } \\
(\%)\end{array}$ & $\begin{array}{c}\text { Microcystis } \\
\text { relative } \\
\text { abundance } \\
(\%)\end{array}$ & $\begin{array}{c}\text { Phormidium } \\
\text { relative } \\
\text { abundance } \\
(\%)\end{array}$ & $\begin{array}{c}\text { Pseudanbaena } \\
\text { relative } \\
\text { abundance } \\
(\%)\end{array}$ \\
\hline \multicolumn{10}{|c|}{ Kansas R at Lecompton, KS (06891000) } \\
\hline $09 / 02 / 11$ & 0.0 & 0.0 & 0.0 & 0.0 & 100 & 0.0 & 0.0 & 0.0 & 0.0 \\
\hline $09 / 08 / 11$ & 3.5 & 0.0 & 0.0 & 0.0 & 0.0 & 0.0 & 82 & 12 & 2.1 \\
\hline $09 / 12 / 11$ & 0.0 & 0.0 & 0.0 & 0.0 & 0.0 & 0.0 & 100 & 0.0 & 0.0 \\
\hline $09 / 20 / 11$ & 100 & 0.0 & 0.0 & 0.0 & 0.0 & 0.0 & 0.0 & 0.0 & 0.0 \\
\hline $09 / 26 / 11$ & 0.0 & 0.0 & 0.0 & 0.0 & 0.0 & 0.0 & 0.0 & 0.0 & 0.0 \\
\hline $10 / 03 / 11$ & 100 & 0.0 & 0.0 & 0.0 & 0.0 & 0.0 & 0.0 & 0.0 & 0.0 \\
\hline $10 / 05 / 11$ & 91 & 0.0 & 0.0 & 0.0 & 0.0 & 0.0 & 9.0 & 0.0 & 0.0 \\
\hline $10 / 11 / 11$ & -- & -- & -- & -- & -- & -- & -- & -- & -- \\
\hline $10 / 17 / 11$ & -- & -- & -- & -- & -- & -- & -- & -- & -- \\
\hline $10 / 24 / 11$ & -- & -- & -- & -- & -- & -- & -- & -- & -- \\
\hline $10 / 31 / 11$ & -- & -- & -- & -- & -- & -- & -- & -- & -- \\
\hline \multicolumn{10}{|c|}{ Kansas R at Lawrence, KS (06891080) } \\
\hline $09 / 02 / 11$ & -- & -- & -- & -- & -- & -- & -- & -- & -- \\
\hline $09 / 08 / 11$ & -- & -- & -- & -- & -- & -- & -- & -- & -- \\
\hline $09 / 12 / 11$ & -- & -- & -- & -- & -- & -- & -- & -- & -- \\
\hline $09 / 20 / 11$ & 0.0 & 0.0 & 0.0 & 0.0 & 0.0 & 0.0 & 0.0 & 0.0 & 0.0 \\
\hline $09 / 26 / 11$ & 0.0 & 0.0 & 0.0 & 0.0 & 0.0 & 0.0 & 0.0 & 0.0 & 0.0 \\
\hline $10 / 03 / 11$ & 100 & 0.0 & 0.0 & 0.0 & 0.0 & 0.0 & 0.0 & 0.0 & 0.0 \\
\hline $10 / 05 / 11$ & -- & -- & -- & -- & -- & -- & -- & -- & -- \\
\hline $10 / 11 / 11$ & -- & -- & -- & -- & -- & -- & -- & -- & -- \\
\hline $10 / 17 / 11$ & -- & -- & -- & -- & -- & -- & -- & -- & -- \\
\hline $10 / 24 / 11$ & -- & -- & -- & -- & -- & -- & -- & -- & -- \\
\hline $10 / 31 / 11$ & -- & -- & -- & -- & -- & -- & -- & -- & -- \\
\hline \multicolumn{10}{|c|}{ Kansas R at Desoto, KS (06892350) } \\
\hline $09 / 02 / 11$ & 0.0 & 0.0 & 0.0 & 0.0 & 51 & 0.0 & 25 & 0.0 & 24 \\
\hline 09/08/11 & 0.0 & 0.0 & 0.0 & 0.0 & 0.0 & 0.0 & 85 & 14 & 0.0 \\
\hline 09/12/11 & 0.0 & 0.0 & 0.0 & 0.0 & 0.0 & 0.0 & 0.0 & 0.0 & 0.0 \\
\hline 09/20/11 & 0.0 & 0.0 & 0.0 & 0.0 & 0.0 & 0.0 & 0.0 & 0.0 & 0.0 \\
\hline $09 / 26 / 11$ & 0.0 & 0.0 & 0.0 & 0.0 & 0.0 & 0.0 & 0.0 & 0.0 & 0.0 \\
\hline $10 / 03 / 11$ & 100 & 0.0 & 0.0 & 0.0 & 0.0 & 0.0 & 0.0 & 0.0 & 0.0 \\
\hline $10 / 05 / 11$ & -- & -- & -- & -- & -- & -- & -- & -- & -- \\
\hline $10 / 11 / 11$ & 0.0 & 0.0 & 0.0 & 0.0 & 0.0 & 0.0 & 0.0 & 0.0 & 0.0 \\
\hline $10 / 17 / 11$ & 0.0 & 0.0 & 0.0 & 0.0 & 0.0 & 0.0 & 0.0 & 0.0 & 0.0 \\
\hline $10 / 24 / 11$ & 0.0 & 0.0 & 0.0 & 0.0 & 0.0 & 0.0 & 0.0 & 0.0 & 0.0 \\
\hline $10 / 31 / 11$ & 0.0 & 0.0 & 100 & 0.0 & 0.0 & 0.0 & 0.0 & 0.0 & 0.0 \\
\hline
\end{tabular}


Appendix 3. Cyanobacterial community composition in samples collected from Kansas River tributary and main-stem sites during September and October 2011.-Continued

[cells/mL, cells per milliliter; \%, percent; nr, near; KS, Kansas; --, sample not collected; nm, analyte not measured but sample archived; R, River; Pl, Plaza]

\begin{tabular}{|c|c|c|c|c|c|c|c|c|c|c|}
\hline Date & $\begin{array}{c}\text { Cyanobacteria } \\
\text { abundance } \\
\text { (cells/mL) }\end{array}$ & $\begin{array}{c}\text { Anabaena } \\
\text { abundance } \\
\text { (cells/mL) }\end{array}$ & $\begin{array}{l}\text { Anabae- } \\
\text { nopsis } \\
\text { abundance } \\
\text { (cells/mL) }\end{array}$ & $\begin{array}{c}\text { Aphanizo- } \\
\text { menon } \\
\text { abundance } \\
\text { (cells/mL }\end{array}$ & $\begin{array}{c}\text { Aphano- } \\
\text { capsa } \\
\text { abundance } \\
\text { (cells/mL) }\end{array}$ & $\begin{array}{l}\text { Chroococ- } \\
\text { cus } \\
\text { abundance } \\
\text { (cells/mL) }\end{array}$ & $\begin{array}{l}\text { Cylindro- } \\
\text { spermopsis } \\
\text { abundance } \\
\text { (cells/mL) }\end{array}$ & $\begin{array}{l}\text { Microcystis } \\
\text { abundance } \\
\text { (cells/mL) }\end{array}$ & $\begin{array}{l}\text { Phormidium } \\
\text { abundance } \\
\text { (cells/mL) }\end{array}$ & $\begin{array}{c}\text { Pseudana- } \\
\text { baena } \\
\text { abundance } \\
\text { (cells/mL) }\end{array}$ \\
\hline \multicolumn{11}{|c|}{ Kansas R nr I-435 Bridge, KS (06892518) } \\
\hline $09 / 02 / 11$ & 13,000 & 0.0 & 0.0 & 0.0 & 0.0 & 2,800 & 0.0 & 1,200 & 0.0 & 9,300 \\
\hline 09/08/11 & 6,600 & 68 & 0.0 & 0.0 & 0.0 & 0.0 & 0.0 & 6,600 & 0.0 & 0.0 \\
\hline $09 / 12 / 11$ & $\mathrm{~nm}$ & $\mathrm{~nm}$ & $\mathrm{~nm}$ & $\mathrm{~nm}$ & $\mathrm{~nm}$ & $\mathrm{~nm}$ & $\mathrm{~nm}$ & $\mathrm{~nm}$ & $\mathrm{~nm}$ & $\mathrm{~nm}$ \\
\hline 09/20/11 & $\mathrm{nm}$ & $\mathrm{nm}$ & $\mathrm{nm}$ & $\mathrm{nm}$ & $\mathrm{nm}$ & $\mathrm{nm}$ & $\mathrm{nm}$ & $\mathrm{nm}$ & $\mathrm{nm}$ & $\mathrm{nm}$ \\
\hline 09/26/11 & $\mathrm{nm}$ & $\mathrm{nm}$ & $\mathrm{nm}$ & $\mathrm{nm}$ & $\mathrm{nm}$ & $\mathrm{nm}$ & $\mathrm{nm}$ & $\mathrm{nm}$ & $\mathrm{nm}$ & $\mathrm{nm}$ \\
\hline $10 / 03 / 11$ & $\mathrm{~nm}$ & $\mathrm{~nm}$ & $\mathrm{~nm}$ & $\mathrm{~nm}$ & $\mathrm{~nm}$ & $\mathrm{~nm}$ & $\mathrm{~nm}$ & $\mathrm{~nm}$ & $\mathrm{~nm}$ & $\mathrm{~nm}$ \\
\hline $10 / 05 / 11$ & -- & -- & -- & -- & -- & -- & -- & -- & -- & -- \\
\hline $10 / 11 / 11$ & -- & -- & -- & -- & -- & -- & -- & -- & -- & -- \\
\hline $10 / 17 / 11$ & -- & -- & -- & -- & -- & -- & -- & -- & -- & -- \\
\hline $10 / 24 / 11$ & -- & -- & -- & -- & -- & -- & -- & -- & -- & -- \\
\hline $10 / 31 / 11$ & -- & -- & -- & -- & -- & -- & -- & -- & -- & -- \\
\hline
\end{tabular}


Appendix 3. Cyanobacterial community composition in samples collected from Kansas River tributary and main-stem sites during September and October 2011.-Continued

[cells/mL, cells per milliliter; \%, percent; nr, near; KS, Kansas; --, sample not collected; nm, analyte not measured but sample archived; R, River; Pl, Plaza]

\begin{tabular}{|c|c|c|c|c|c|c|c|c|c|}
\hline Date & $\begin{array}{c}\text { Anabaena } \\
\text { relative } \\
\text { abundance } \\
(\%)\end{array}$ & $\begin{array}{c}\text { Anabaenopsis } \\
\text { relative } \\
\text { abundance } \\
(\%)\end{array}$ & $\begin{array}{l}\text { Aphanizo- } \\
\text { menon } \\
\text { relative } \\
\text { abundance } \\
(\%)\end{array}$ & $\begin{array}{c}\text { Aphanocapsa } \\
\text { relative } \\
\text { abundance } \\
(\%)\end{array}$ & $\begin{array}{l}\text { Chroococcus } \\
\text { relative } \\
\text { abundance } \\
(\%)\end{array}$ & $\begin{array}{l}\text { Cylindrosper- } \\
\text { mopsis } \\
\text { relative } \\
\text { abundance } \\
(\%)\end{array}$ & $\begin{array}{c}\text { Microcystis } \\
\text { relative } \\
\text { abundance } \\
(\%)\end{array}$ & $\begin{array}{l}\text { Phormidium } \\
\text { relative } \\
\text { abundance } \\
(\%)\end{array}$ & $\begin{array}{c}\text { Pseudanbaena } \\
\text { relative } \\
\text { abundance } \\
(\%)\end{array}$ \\
\hline \multicolumn{10}{|c|}{ Kansas R nr I-435 Bridge, KS (06892518) } \\
\hline $09 / 02 / 11$ & 0.0 & 0.0 & 0.0 & 0.0 & 21 & 0.0 & 9.0 & 0.0 & 70 \\
\hline 09/08/11 & 1.0 & 0.0 & 0.0 & 0.0 & 0.0 & 0.0 & 99 & 0.0 & 0.0 \\
\hline $09 / 12 / 11$ & $\mathrm{~nm}$ & $\mathrm{~nm}$ & $\mathrm{~nm}$ & $\mathrm{~nm}$ & $\mathrm{~nm}$ & $\mathrm{~nm}$ & $\mathrm{~nm}$ & $\mathrm{~nm}$ & $\mathrm{~nm}$ \\
\hline 09/20/11 & $\mathrm{nm}$ & $\mathrm{nm}$ & $\mathrm{nm}$ & $\mathrm{nm}$ & $\mathrm{nm}$ & $\mathrm{nm}$ & $\mathrm{nm}$ & $\mathrm{nm}$ & $\mathrm{nm}$ \\
\hline $09 / 26 / 11$ & $\mathrm{~nm}$ & $\mathrm{~nm}$ & $\mathrm{~nm}$ & $\mathrm{~nm}$ & $\mathrm{~nm}$ & $\mathrm{~nm}$ & $\mathrm{~nm}$ & $\mathrm{~nm}$ & $\mathrm{~nm}$ \\
\hline $10 / 03 / 11$ & $\mathrm{~nm}$ & $\mathrm{~nm}$ & $\mathrm{~nm}$ & $\mathrm{~nm}$ & $\mathrm{~nm}$ & $\mathrm{~nm}$ & $\mathrm{~nm}$ & $\mathrm{~nm}$ & $\mathrm{~nm}$ \\
\hline $10 / 05 / 11$ & -- & -- & -- & -- & -- & -- & -- & -- & -- \\
\hline $10 / 11 / 11$ & -- & -- & -- & -- & -- & -- & -- & -- & -- \\
\hline $10 / 17 / 11$ & -- & -- & -- & -- & -- & -- & -- & -- & -- \\
\hline $10 / 24 / 11$ & -- & -- & -- & -- & -- & -- & -- & -- & -- \\
\hline $10 / 31 / 11$ & -- & -- & -- & -- & -- & -- & -- & -- & -- \\
\hline
\end{tabular}


Appendix 4. Phytoplankton community composition in samples collected from Kansas River tributary and main-stem sites during September and October 2011.

[cells/mL, cells per milliliter; \%, percent; nr, near; KS, Kansas; --, sample not collected; nm, analyte not measured but sample archived; R, River; Pl, Plaza]

\begin{tabular}{|c|c|c|c|c|c|c|c|c|}
\hline Date & $\begin{array}{l}\text { Phytoplankton } \\
\text { abundance } \\
\text { (cells/mL) }\end{array}$ & $\begin{array}{l}\text { Bacillariophyta } \\
\text { abundance } \\
\text { (cells/mL) }\end{array}$ & $\begin{array}{l}\text { Chlorophyta } \\
\text { abundance } \\
\text { (cells/mL) }\end{array}$ & $\begin{array}{l}\text { Chrysophyta } \\
\text { abundance } \\
\text { (cells/mL) }\end{array}$ & $\begin{array}{l}\text { Cryptophyta } \\
\text { abundance } \\
\text { (cells/mL) }\end{array}$ & $\begin{array}{c}\text { Cyanophyta } \\
\text { abundance } \\
\text { (cells/mL) }\end{array}$ & $\begin{array}{c}\text { Euglenophyta } \\
\text { abundance } \\
\text { (cells/mL) }\end{array}$ & $\begin{array}{c}\text { Pyrrophyta } \\
\text { abundance } \\
\text { (cells } / \mathrm{mL} \text { ) }\end{array}$ \\
\hline \multicolumn{9}{|c|}{ Milford Reservoir sampling sites } \\
\hline \multicolumn{9}{|c|}{ Milford Lake nr Junction City, KS (06857050) } \\
\hline 09/02/11 & $600,000,000$ & 0.0 & 0.0 & 0.0 & 0.0 & $600,000,000$ & 0.0 & 0.0 \\
\hline 09/08/11 & -- & -- & -- & -- & -- & -- & -- & -- \\
\hline 09/12/11 & -- & -- & -- & -- & -- & -- & -- & -- \\
\hline 09/20/11 & -- & -- & -- & -- & -- & -- & -- & -- \\
\hline 09/26/11 & $\mathrm{nm}$ & $\mathrm{nm}$ & $\mathrm{nm}$ & $\mathrm{nm}$ & $\mathrm{nm}$ & $\mathrm{nm}$ & $\mathrm{nm}$ & $\mathrm{nm}$ \\
\hline $10 / 03 / 11$ & $\mathrm{~nm}$ & $\mathrm{~nm}$ & $\mathrm{~nm}$ & $\mathrm{~nm}$ & $\mathrm{~nm}$ & $\mathrm{~nm}$ & $\mathrm{~nm}$ & $\mathrm{~nm}$ \\
\hline $10 / 05 / 11$ & -- & -- & -- & -- & -- & -- & -- & -- \\
\hline 10/11/11 & -- & -- & -- & -- & -- & -- & -- & -- \\
\hline $10 / 17 / 11$ & -- & -- & -- & -- & -- & -- & -- & -- \\
\hline $10 / 24 / 11$ & -- & -- & -- & -- & -- & -- & -- & -- \\
\hline $10 / 31 / 11$ & -- & -- & -- & -- & -- & -- & -- & -- \\
\hline \multicolumn{9}{|c|}{ Milford Lake outlet, KS (390433096534600) } \\
\hline $09 / 02 / 11$ & 28,000 & 55 & 9.1 & 0.0 & 160 & 28,000 & 0.0 & 0.0 \\
\hline 09/08/11 & 17,000 & 100 & 62 & 0.0 & 260 & 17,000 & 0.0 & 0.0 \\
\hline $09 / 12 / 11$ & $\mathrm{~nm}$ & $\mathrm{~nm}$ & $\mathrm{~nm}$ & $\mathrm{~nm}$ & $\mathrm{~nm}$ & $\mathrm{~nm}$ & $\mathrm{~nm}$ & $\mathrm{~nm}$ \\
\hline 09/20/11 & $\mathrm{nm}$ & $\mathrm{nm}$ & $\mathrm{nm}$ & $\mathrm{nm}$ & $\mathrm{nm}$ & $\mathrm{nm}$ & $\mathrm{nm}$ & $\mathrm{nm}$ \\
\hline 09/26/11 & $\mathrm{nm}$ & $\mathrm{nm}$ & $\mathrm{nm}$ & $\mathrm{nm}$ & $\mathrm{nm}$ & $\mathrm{nm}$ & $\mathrm{nm}$ & $\mathrm{nm}$ \\
\hline $10 / 03 / 11$ & $\mathrm{~nm}$ & $\mathrm{~nm}$ & $\mathrm{~nm}$ & $\mathrm{~nm}$ & $\mathrm{~nm}$ & $\mathrm{~nm}$ & $\mathrm{~nm}$ & $\mathrm{~nm}$ \\
\hline $10 / 05 / 11$ & -- & -- & -- & -- & -- & -- & -- & -- \\
\hline $10 / 11 / 11$ & -- & -- & -- & -- & -- & -- & -- & -- \\
\hline $10 / 17 / 11$ & -- & -- & -- & -- & -- & -- & -- & -- \\
\hline $10 / 24 / 11$ & -- & -- & -- & -- & -- & -- & -- & -- \\
\hline $10 / 31 / 11$ & -- & -- & -- & -- & -- & -- & -- & -- \\
\hline \multicolumn{9}{|c|}{ Kansas River tributary sampling sites } \\
\hline \multicolumn{9}{|c|}{ Smoky Hill R at Grandview PI, Junction City, KS (06879005) } \\
\hline $09 / 02 / 11$ & 17,000 & 12,000 & 770 & 0.0 & 4,100 & 0.0 & 8.0 & 0.0 \\
\hline 09/08/11 & 71,000 & 59,000 & 2,400 & 0.0 & 9,700 & 0.0 & 0.0 & 0.0 \\
\hline $09 / 12 / 11$ & 100,000 & 95,000 & 2,000 & 0.0 & 3,600 & 0.0 & 0.0 & 0.0 \\
\hline 09/20/11 & 91,000 & 86,000 & 2,400 & 0.0 & 1,900 & 0.0 & 0.0 & 0.0 \\
\hline $09 / 26 / 11$ & 160,000 & 140,000 & 7,400 & 0.0 & 10,000 & 72 & 0.0 & 0.0 \\
\hline $10 / 03 / 11$ & 120,000 & 120,000 & 4,300 & 0.0 & 3,700 & 560 & 0.0 & 0.0 \\
\hline $10 / 05 / 11$ & -- & -- & -- & -- & -- & -- & -- & -- \\
\hline $10 / 11 / 11$ & -- & -- & -- & -- & -- & -- & -- & -- \\
\hline $10 / 17 / 11$ & -- & -- & -- & -- & -- & -- & -- & -- \\
\hline $10 / 24 / 11$ & -- & -- & -- & -- & -- & -- & -- & -- \\
\hline $10 / 31 / 11$ & -- & -- & -- & -- & -- & -- & -- & -- \\
\hline
\end{tabular}


Appendix 4. Phytoplankton community composition in samples collected from Kansas River tributary and main-stem sites during September and October 2011.-Continued

[cells/mL, cells per milliliter; \%, percent; nr, near; KS, Kansas; --, sample not collected; nm, analyte not measured but sample archived; R, River; Pl, Plaza]

\begin{tabular}{|c|c|c|c|c|c|c|c|}
\hline Date & $\begin{array}{l}\text { Bacillariophyta } \\
\text { relative } \\
\text { abundance } \\
(\%)\end{array}$ & $\begin{array}{l}\text { Chlorophyta } \\
\text { relative } \\
\text { abundance } \\
(\%)\end{array}$ & $\begin{array}{c}\text { Chrysophyta } \\
\text { relative } \\
\text { abundance } \\
(\%)\end{array}$ & $\begin{array}{c}\text { Cryptophyta } \\
\text { relative } \\
\text { abundance } \\
(\%)\end{array}$ & $\begin{array}{c}\text { Cyanophyta } \\
\text { relative } \\
\text { abundance } \\
(\%)\end{array}$ & $\begin{array}{c}\text { Euglenophyta } \\
\text { relative } \\
\text { abundance } \\
(\%)\end{array}$ & $\begin{array}{c}\text { Pyrrophyta } \\
\text { relative } \\
\text { abundance } \\
(\%)\end{array}$ \\
\hline \multicolumn{8}{|c|}{ Milford Reservoir sampling sites } \\
\hline \multicolumn{8}{|c|}{ Milford Lake nr Junction City, KS (06857050) } \\
\hline $09 / 02 / 11$ & 0.0 & 0.0 & 0.0 & 0.0 & 100 & 0.0 & 0.0 \\
\hline $09 / 08 / 11$ & -- & -- & -- & -- & -- & -- & -- \\
\hline $09 / 12 / 11$ & -- & -- & -- & -- & -- & -- & -- \\
\hline $09 / 20 / 11$ & -- & -- & -- & -- & -- & -- & -- \\
\hline $09 / 26 / 11$ & $\mathrm{~nm}$ & $\mathrm{~nm}$ & $\mathrm{~nm}$ & $\mathrm{~nm}$ & $\mathrm{~nm}$ & $\mathrm{~nm}$ & $\mathrm{~nm}$ \\
\hline $10 / 03 / 11$ & $\mathrm{~nm}$ & $\mathrm{~nm}$ & $\mathrm{~nm}$ & $\mathrm{~nm}$ & $\mathrm{~nm}$ & $\mathrm{~nm}$ & $\mathrm{~nm}$ \\
\hline $10 / 05 / 11$ & -- & -- & -- & -- & -- & -- & -- \\
\hline $10 / 11 / 11$ & -- & -- & -- & -- & -- & -- & -- \\
\hline $10 / 17 / 11$ & -- & -- & -- & -- & -- & -- & -- \\
\hline $10 / 24 / 11$ & -- & -- & -- & -- & -- & -- & -- \\
\hline $10 / 31 / 11$ & -- & -- & -- & -- & -- & -- & -- \\
\hline \multicolumn{8}{|c|}{ Milford Lake outlet, KS (390433096534600) } \\
\hline $09 / 02 / 11$ & 0.19 & 0.03 & 0.0 & 0.55 & 99 & 0.0 & 0.0 \\
\hline $09 / 08 / 11$ & 0.60 & 0.37 & 0.0 & 1.5 & 97 & 0.0 & 0.0 \\
\hline $09 / 12 / 11$ & $\mathrm{~nm}$ & $\mathrm{~nm}$ & $\mathrm{~nm}$ & $\mathrm{~nm}$ & $\mathrm{~nm}$ & $\mathrm{~nm}$ & $\mathrm{~nm}$ \\
\hline $09 / 20 / 11$ & $\mathrm{~nm}$ & $\mathrm{~nm}$ & $\mathrm{~nm}$ & $\mathrm{~nm}$ & $\mathrm{~nm}$ & $\mathrm{~nm}$ & $\mathrm{~nm}$ \\
\hline $09 / 26 / 11$ & $\mathrm{~nm}$ & $\mathrm{~nm}$ & $\mathrm{~nm}$ & $\mathrm{~nm}$ & $\mathrm{~nm}$ & $\mathrm{~nm}$ & $\mathrm{~nm}$ \\
\hline $10 / 03 / 11$ & $\mathrm{~nm}$ & $\mathrm{~nm}$ & $\mathrm{~nm}$ & $\mathrm{~nm}$ & $\mathrm{~nm}$ & $\mathrm{~nm}$ & $\mathrm{~nm}$ \\
\hline $10 / 05 / 11$ & -- & -- & -- & -- & -- & -- & -- \\
\hline $10 / 11 / 11$ & -- & -- & -- & -- & -- & -- & -- \\
\hline $10 / 17 / 11$ & -- & -- & -- & -- & -- & -- & -- \\
\hline $10 / 24 / 11$ & -- & -- & -- & -- & -- & -- & -- \\
\hline $10 / 31 / 11$ & -- & -- & -- & -- & -- & -- & -- \\
\hline \multicolumn{8}{|c|}{ Kansas River tributary sampling sites } \\
\hline \multicolumn{8}{|c|}{ Smoky Hill R at Grandview PI, Junction City, KS (06879005) } \\
\hline $09 / 02 / 11$ & 71 & 4.5 & 0.0 & 24 & 0.0 & 0.047 & 0.0 \\
\hline $09 / 08 / 11$ & 83 & 3.4 & 0.0 & 14 & 0.0 & 0.0 & 0.0 \\
\hline $09 / 12 / 11$ & 94 & 2.0 & 0.0 & 3.6 & 0.0 & 0.0 & 0.0 \\
\hline $09 / 20 / 11$ & 95 & 2.7 & 0.0 & 2.1 & 0.0 & 0.0 & 0.0 \\
\hline $09 / 26 / 11$ & 89 & 4.6 & 0.0 & 6.2 & 0.026 & 0.0 & 0.0 \\
\hline $10 / 03 / 11$ & 93 & 3.5 & 0.0 & 3.0 & 0.45 & 0.0 & 0.0 \\
\hline $10 / 05 / 11$ & -- & -- & -- & -- & -- & -- & -- \\
\hline $10 / 11 / 11$ & -- & -- & -- & -- & -- & -- & -- \\
\hline $10 / 17 / 11$ & -- & -- & -- & -- & -- & -- & -- \\
\hline $10 / 24 / 11$ & -- & -- & -- & -- & -- & -- & -- \\
\hline $10 / 31 / 11$ & -- & -- & -- & -- & -- & -- & -- \\
\hline
\end{tabular}


Appendix 4. Phytoplankton community composition in samples collected from Kansas River tributary and main-stem sites during September and October 2011.-Continued

[cells/mL, cells per milliliter; \%, percent; nr, near; KS, Kansas; --, sample not collected; nm, analyte not measured but sample archived; R, River; Pl, Plaza]

\begin{tabular}{|c|c|c|c|c|c|c|c|c|}
\hline Date & $\begin{array}{l}\text { Phytoplankton } \\
\text { abundance } \\
\text { (cells/mL) }\end{array}$ & $\begin{array}{c}\text { Bacillariophyta } \\
\text { abundance } \\
\text { (cells/mL) }\end{array}$ & $\begin{array}{c}\text { Chlorophyta } \\
\text { abundance } \\
\text { (cells/mL) }\end{array}$ & $\begin{array}{l}\text { Chrysophyta } \\
\text { abundance } \\
\text { (cells/mL) }\end{array}$ & $\begin{array}{l}\text { Cryptophyta } \\
\text { abundance } \\
\text { (cells/mL) }\end{array}$ & $\begin{array}{c}\text { Cyanophyta } \\
\text { abundance } \\
\text { (cells/mL) }\end{array}$ & $\begin{array}{l}\text { Euglenophyta } \\
\text { abundance } \\
\text { (cells/mL) }\end{array}$ & $\begin{array}{c}\text { Pyrrophyta } \\
\text { abundance } \\
\text { (cells/mL) }\end{array}$ \\
\hline \multicolumn{9}{|c|}{ Republican R at Junction City, KS (06857100) } \\
\hline $09 / 02 / 11$ & 29,000 & 260 & 150 & 0.0 & 560 & 28,000 & 0.0 & 0.0 \\
\hline 09/08/11 & 26,000 & 140 & 29 & 0.0 & 390 & 25,000 & 0.0 & 0.0 \\
\hline 09/12/11 & 5,100 & 67 & 210 & 0.0 & 1,100 & 3,700 & 0.0 & 0.0 \\
\hline $09 / 20 / 11$ & 1,000 & 19 & 26 & 0.0 & 250 & 760 & 0.0 & 0.0 \\
\hline $09 / 26 / 11$ & 1,100 & 300 & 52 & 0.0 & 380 & 380 & 0.0 & 0.0 \\
\hline $10 / 03 / 11$ & 1,100 & 270 & 61 & 0.0 & 390 & 380 & 0.0 & 0.0 \\
\hline $10 / 05 / 11$ & -- & -- & -- & -- & -- & -- & -- & -- \\
\hline $10 / 11 / 11$ & 820 & 200 & 24 & 0.0 & 370 & 230 & 0.0 & 0.0 \\
\hline $10 / 17 / 11$ & 5,900 & 2,800 & 230 & 0.0 & 2,900 & 0.0 & 0.0 & 0.0 \\
\hline $10 / 24 / 11$ & 2,300 & 1,500 & 78 & 0.0 & 750 & 0.0 & 0.0 & 0.0 \\
\hline $10 / 31 / 11$ & 1,300 & 980 & 8.9 & 0.0 & 290 & 0.0 & 0.0 & 0.0 \\
\hline \multicolumn{9}{|c|}{ Big Blue R nr Manhattan, KS (06887000) } \\
\hline $09 / 02 / 11$ & 2,100 & 1,500 & 160 & 0.0 & 530 & 0.0 & 0.20 & 0.0 \\
\hline 09/08/11 & 4,000 & 1,800 & 410 & 0.0 & 960 & 830 & 0.0 & 0.0 \\
\hline $09 / 12 / 11$ & 4,700 & 3,500 & 310 & 1.0 & 880 & 0.0 & 0.0 & 0.0 \\
\hline 09/20/11 & 1,900 & 1,300 & 53 & 0.0 & 550 & 0.0 & 0.0 & 0.0 \\
\hline 09/26/11 & 1,100 & 510 & 77 & 0.0 & 470 & 0.0 & 0.0 & 0.0 \\
\hline $10 / 03 / 11$ & 5,200 & 4,100 & 710 & 0.0 & 350 & 0.0 & 0.0 & 0.0 \\
\hline $10 / 05 / 11$ & -- & -- & -- & -- & -- & -- & -- & -- \\
\hline $10 / 11 / 11$ & 6,000 & 5,100 & 360 & 0.0 & 480 & 0.0 & 0.0 & 0.0 \\
\hline $10 / 17 / 11$ & 4,500 & 3,200 & 440 & 0.0 & 910 & 0.0 & 0.0 & 0.0 \\
\hline $10 / 24 / 11$ & 7,600 & 6,700 & 30 & 0.0 & 870 & 0.0 & 0.0 & 0.0 \\
\hline $10 / 31 / 11$ & 6,900 & 5,300 & 220 & 0.0 & 1,400 & 0.0 & 0.0 & 0.0 \\
\hline \multicolumn{9}{|c|}{ Delaware R at Perry, KS (06890900) } \\
\hline $09 / 02 / 11$ & 4,800 & 1,400 & 620 & 0.0 & 2,800 & 43 & 29 & 0.0 \\
\hline 09/08/11 & 9,900 & 3,500 & 830 & 0.20 & 3,000 & 2,500 & 0.0 & 7.3 \\
\hline 09/12/11 & 6,400 & 3,500 & 480 & 0.0 & 2,500 & 0.0 & 0.0 & 0.0 \\
\hline 09/20/11 & 2,100 & 1,700 & 63 & 0.0 & 330 & 0.0 & 0.0 & 1.0 \\
\hline 09/26/11 & 2,700 & 1,900 & 290 & 0.0 & 530 & 0.0 & 0.0 & 0.0 \\
\hline $10 / 03 / 11$ & -- & -- & -- & -- & -- & -- & -- & -- \\
\hline $10 / 05 / 11$ & -- & -- & -- & -- & -- & -- & -- & -- \\
\hline $10 / 11 / 11$ & 11,000 & 5,200 & 2,000 & 0.0 & 3,600 & 49 & 0.0 & 0.0 \\
\hline $10 / 17 / 11$ & 1,700 & 530 & 36 & 0.0 & 1,000 & 95 & 0.0 & 0.0 \\
\hline $10 / 24 / 11$ & 7,900 & 2,500 & 660 & 0.0 & 4,600 & 160 & 0.0 & 0.0 \\
\hline $10 / 31 / 11$ & 7,300 & 5,600 & 190 & 0.0 & 1,400 & 32 & 0.0 & 0.0 \\
\hline
\end{tabular}


Appendix 4. Phytoplankton community composition in samples collected from Kansas River tributary and main-stem sites during September and October 2011.-Continued

[cells/mL, cells per milliliter; \%, percent; nr, near; KS, Kansas; --, sample not collected; nm, analyte not measured but sample archived; R, River; Pl, Plaza]

\begin{tabular}{|c|c|c|c|c|c|c|c|}
\hline Date & $\begin{array}{c}\text { Bacillariophyta } \\
\text { relative } \\
\text { abundance } \\
(\%)\end{array}$ & $\begin{array}{c}\text { Chlorophyta } \\
\text { relative } \\
\text { abundance } \\
(\%)\end{array}$ & $\begin{array}{c}\text { Chrysophyta } \\
\text { relative } \\
\text { abundance } \\
(\%)\end{array}$ & $\begin{array}{l}\text { Cryptophyta } \\
\text { relative } \\
\text { abundance } \\
(\%)\end{array}$ & $\begin{array}{l}\text { Cyanophyta } \\
\text { relative } \\
\text { abundance } \\
(\%)\end{array}$ & $\begin{array}{c}\text { Euglenophyta } \\
\text { relative } \\
\text { abundance } \\
(\%)\end{array}$ & $\begin{array}{c}\text { Pyrrophyta } \\
\text { relative } \\
\text { abundance } \\
(\%)\end{array}$ \\
\hline \multicolumn{8}{|c|}{ Republican R at Junction City, KS (06857100) } \\
\hline $09 / 02 / 11$ & 0.88 & 0.50 & 0.0 & 1.9 & 97 & 0.0 & 0.0 \\
\hline 09/08/11 & 0.54 & 0.11 & 0.0 & 1.5 & 98 & 0.0 & 0.0 \\
\hline $09 / 12 / 11$ & 1.3 & 4.1 & 0.0 & 21 & 73 & 0.0 & 0.0 \\
\hline $09 / 20 / 11$ & 1.8 & 2.5 & 0.0 & 23 & 72 & 0.0 & 0.0 \\
\hline $09 / 26 / 11$ & 27 & 4.6 & 0.0 & 34 & 35 & 0.0 & 0.0 \\
\hline $10 / 03 / 11$ & 24 & 5.5 & 0.0 & 36 & 34 & 0.0 & 0.0 \\
\hline $10 / 05 / 11$ & -- & -- & -- & -- & -- & -- & -- \\
\hline $10 / 11 / 11$ & 24 & 3.0 & 0.0 & 45 & 28 & 0.0 & 0.0 \\
\hline $10 / 17 / 11$ & 47 & 3.9 & 0.0 & 49 & 0.0 & 0.0 & 0.0 \\
\hline $10 / 24 / 11$ & 65 & 3.3 & 0.0 & 32 & 0.0 & 0.0 & 0.0 \\
\hline $10 / 31 / 11$ & 77 & 0.70 & 0.0 & 23 & 0.0 & 0.0 & 0.0 \\
\hline \multicolumn{8}{|c|}{ Big Blue R nr Manhattan, KS (06887000) } \\
\hline $09 / 02 / 11$ & 67 & 7.6 & 0.0 & 25 & 0.0 & 0.0093 & 0.0 \\
\hline 09/08/11 & 45 & 10 & 0.0 & 24 & 21 & 0.0 & 0.0 \\
\hline $09 / 12 / 11$ & 75 & 6.5 & 0.021 & 19 & 0.0 & 0.0 & 0.0 \\
\hline 09/20/11 & 68 & 2.8 & 0.0 & 29 & 0.0 & 0.0 & 0.0 \\
\hline $09 / 26 / 11$ & 48 & 7.3 & 0.0 & 44 & 0.0 & 0.0 & 0.0 \\
\hline $10 / 03 / 11$ & 79 & 14 & 0.0 & 6.8 & 0.0 & 0.0 & 0.0 \\
\hline $10 / 05 / 11$ & -- & -- & -- & -- & -- & -- & -- \\
\hline $10 / 11 / 11$ & 86 & 6.1 & 0.0 & 8.1 & 0.0 & 0.0 & 0.0 \\
\hline $10 / 17 / 11$ & 70 & 9.7 & 0.0 & 20 & 0.0 & 0.0 & 0.0 \\
\hline $10 / 24 / 11$ & 88 & 0.39 & 0.0 & 11 & 0.0 & 0.0 & 0.0 \\
\hline $10 / 31 / 11$ & 76 & 3.2 & 0.0 & 21 & 0.0 & 0.0 & 0.0 \\
\hline \multicolumn{8}{|c|}{ Delaware R at Perry, KS (06890900) } \\
\hline $09 / 02 / 11$ & 28 & 13 & 0.0 & 57 & 0.88 & 0.59 & 0.0 \\
\hline 09/08/11 & 36 & 8.4 & 0.0020 & 30 & 26 & 0.0 & 0.073 \\
\hline $09 / 12 / 11$ & 54 & 7.5 & 0.0 & 38 & 0.0 & 0.0 & 0.0 \\
\hline $09 / 20 / 11$ & 81 & 3.1 & 0.0 & 16 & 0.0 & 0.0 & 0.049 \\
\hline $09 / 26 / 11$ & 70 & 11 & 0.0 & 20 & 0.0 & 0.0 & 0.0 \\
\hline $10 / 03 / 11$ & -- & -- & -- & -- & -- & -- & -- \\
\hline $10 / 05 / 11$ & -- & -- & -- & -- & -- & -- & -- \\
\hline $10 / 11 / 11$ & 48 & 18 & 0.0 & 33 & 0.45 & 0.0 & 0.0 \\
\hline $10 / 17 / 11$ & 32 & 2.2 & 0.0 & 60 & 5.7 & 0.0 & 0.0 \\
\hline $10 / 24 / 11$ & 32 & 8.4 & 0.0 & 58 & 2.0 & 0.0 & 0.0 \\
\hline $10 / 31 / 11$ & 77 & 2.5 & 0.0 & 20 & 0.44 & 0.0 & 0.0 \\
\hline
\end{tabular}


Appendix 4. Phytoplankton community composition in samples collected from Kansas River tributary and main-stem sites during September and October 2011.-Continued

[cells/mL, cells per milliliter; \%, percent; nr, near; KS, Kansas; --, sample not collected; nm, analyte not measured but sample archived; R, River; Pl, Plaza]

\begin{tabular}{|c|c|c|c|c|c|c|c|c|}
\hline Date & $\begin{array}{l}\text { Phytoplankton } \\
\text { abundance } \\
\text { (cells/mL) }\end{array}$ & $\begin{array}{c}\text { Bacillariophyta } \\
\text { abundance } \\
\text { (cells/mL) }\end{array}$ & $\begin{array}{l}\text { Chlorophyta } \\
\text { abundance } \\
\text { (cells/mL) }\end{array}$ & $\begin{array}{l}\text { Chrysophyta } \\
\text { abundance } \\
\text { (cells/mL) }\end{array}$ & $\begin{array}{l}\text { Cryptophyta } \\
\text { abundance } \\
\text { (cells/mL) }\end{array}$ & $\begin{array}{c}\text { Cyanophyta } \\
\text { abundance } \\
\text { (cells/mL) }\end{array}$ & $\begin{array}{l}\text { Euglenophyta } \\
\text { abundance } \\
\text { (cells/mL) }\end{array}$ & $\begin{array}{c}\text { Pyrrophyta } \\
\text { abundance } \\
\text { (cells } / \mathrm{mL} \text { ) }\end{array}$ \\
\hline \multicolumn{9}{|c|}{ Wakarusa R nr Lawrence, KS (06891500) } \\
\hline $09 / 02 / 11$ & 7,000 & 1,800 & 630 & 0.0 & 1,900 & 2,700 & 1.0 & 0.0 \\
\hline $09 / 08 / 11$ & 2,700 & 1200 & 250 & 4.9 & 630 & 640 & 0.20 & 0.0 \\
\hline $09 / 12 / 11$ & $\mathrm{~nm}$ & $\mathrm{~nm}$ & $\mathrm{~nm}$ & $\mathrm{~nm}$ & $\mathrm{~nm}$ & $\mathrm{~nm}$ & $\mathrm{~nm}$ & $\mathrm{~nm}$ \\
\hline $09 / 20 / 11$ & $\mathrm{~nm}$ & $\mathrm{~nm}$ & $\mathrm{~nm}$ & $\mathrm{~nm}$ & $\mathrm{~nm}$ & $\mathrm{~nm}$ & $\mathrm{~nm}$ & $\mathrm{~nm}$ \\
\hline $09 / 26 / 11$ & $\mathrm{~nm}$ & $\mathrm{~nm}$ & $\mathrm{~nm}$ & $\mathrm{~nm}$ & $\mathrm{~nm}$ & $\mathrm{~nm}$ & $\mathrm{~nm}$ & $\mathrm{~nm}$ \\
\hline $10 / 03 / 11$ & $\mathrm{~nm}$ & $\mathrm{~nm}$ & $\mathrm{~nm}$ & $\mathrm{~nm}$ & $\mathrm{~nm}$ & $\mathrm{~nm}$ & $\mathrm{~nm}$ & $\mathrm{~nm}$ \\
\hline $10 / 05 / 11$ & -- & -- & -- & -- & -- & -- & -- & -- \\
\hline $10 / 11 / 11$ & -- & -- & -- & -- & -- & -- & -- & -- \\
\hline $10 / 17 / 11$ & -- & -- & -- & -- & -- & -- & -- & -- \\
\hline $10 / 24 / 11$ & -- & -- & -- & -- & -- & -- & -- & -- \\
\hline $10 / 31 / 11$ & -- & -- & -- & -- & -- & -- & -- & -- \\
\hline \multicolumn{9}{|c|}{ Kansas River main-stem sampling sites } \\
\hline \multicolumn{9}{|c|}{ Kansas R at Fort Riley, KS (06879100) } \\
\hline $09 / 02 / 11$ & 34,000 & 8,900 & 590 & 0.0 & 4,400 & 20,000 & 0.0 & 0.0 \\
\hline 09/08/11 & 27,000 & 19,000 & 1,100 & 0.0 & 2,700 & 3,900 & 2.0 & 0.0 \\
\hline $09 / 12 / 11$ & $\mathrm{~nm}$ & $\mathrm{~nm}$ & $\mathrm{~nm}$ & $\mathrm{~nm}$ & $\mathrm{~nm}$ & $\mathrm{~nm}$ & $\mathrm{~nm}$ & $\mathrm{~nm}$ \\
\hline $09 / 20 / 11$ & $\mathrm{~nm}$ & $\mathrm{~nm}$ & $\mathrm{~nm}$ & $\mathrm{~nm}$ & $\mathrm{~nm}$ & $\mathrm{~nm}$ & $\mathrm{~nm}$ & $\mathrm{~nm}$ \\
\hline $09 / 26 / 11$ & $\mathrm{~nm}$ & $\mathrm{~nm}$ & $\mathrm{~nm}$ & $\mathrm{~nm}$ & $\mathrm{~nm}$ & $\mathrm{~nm}$ & $\mathrm{~nm}$ & $\mathrm{~nm}$ \\
\hline $10 / 03 / 11$ & $\mathrm{~nm}$ & $\mathrm{~nm}$ & $\mathrm{~nm}$ & $\mathrm{~nm}$ & $\mathrm{~nm}$ & $\mathrm{~nm}$ & $\mathrm{~nm}$ & $\mathrm{~nm}$ \\
\hline $10 / 05 / 11$ & -- & -- & -- & -- & -- & -- & -- & -- \\
\hline $10 / 11 / 11$ & -- & -- & -- & -- & -- & -- & -- & -- \\
\hline $10 / 17 / 11$ & -- & -- & -- & -- & -- & -- & -- & -- \\
\hline $10 / 24 / 11$ & -- & -- & -- & -- & -- & -- & -- & -- \\
\hline $10 / 31 / 11$ & -- & -- & -- & -- & -- & -- & -- & -- \\
\hline \multicolumn{9}{|c|}{ Kansas R at Manhattan, KS (06879820) } \\
\hline $09 / 02 / 11$ & 19,000 & 9,800 & 580 & 0.0 & 2,300 & 6,400 & 0.67 & 0.0 \\
\hline 09/08/11 & 41,000 & 30,000 & 2,800 & 0.0 & 3,200 & 4,700 & 0.0 & 0.0 \\
\hline $09 / 12 / 11$ & $\mathrm{~nm}$ & $\mathrm{~nm}$ & $\mathrm{~nm}$ & $\mathrm{~nm}$ & $\mathrm{~nm}$ & $\mathrm{~nm}$ & $\mathrm{~nm}$ & $\mathrm{~nm}$ \\
\hline 09/20/11 & $\mathrm{nm}$ & $\mathrm{nm}$ & $\mathrm{nm}$ & $\mathrm{nm}$ & $\mathrm{nm}$ & $\mathrm{nm}$ & $\mathrm{nm}$ & $\mathrm{nm}$ \\
\hline $09 / 26 / 11$ & $\mathrm{~nm}$ & $\mathrm{~nm}$ & $\mathrm{~nm}$ & $\mathrm{~nm}$ & $\mathrm{~nm}$ & $\mathrm{~nm}$ & $\mathrm{~nm}$ & $\mathrm{~nm}$ \\
\hline $10 / 03 / 11$ & $\mathrm{~nm}$ & $\mathrm{~nm}$ & $\mathrm{~nm}$ & $\mathrm{~nm}$ & $\mathrm{~nm}$ & $\mathrm{~nm}$ & $\mathrm{~nm}$ & $\mathrm{~nm}$ \\
\hline $10 / 05 / 11$ & -- & -- & -- & -- & -- & -- & -- & -- \\
\hline $10 / 11 / 11$ & -- & -- & -- & -- & -- & -- & -- & -- \\
\hline $10 / 17 / 11$ & -- & -- & -- & -- & -- & -- & -- & -- \\
\hline $10 / 24 / 11$ & -- & -- & -- & -- & -- & -- & -- & -- \\
\hline $10 / 31 / 11$ & -- & -- & -- & -- & -- & -- & -- & -- \\
\hline
\end{tabular}


Appendix 4. Phytoplankton community composition in samples collected from Kansas River tributary and main-stem sites during September and October 2011.-Continued

[cells/mL, cells per milliliter; \%, percent; nr, near; KS, Kansas; --, sample not collected; nm, analyte not measured but sample archived; R, River; Pl, Plaza]

\begin{tabular}{|c|c|c|c|c|c|c|c|}
\hline Date & $\begin{array}{l}\text { Bacillariophyta } \\
\text { relative } \\
\text { abundance } \\
(\%)\end{array}$ & $\begin{array}{l}\text { Chlorophyta } \\
\text { relative } \\
\text { abundance } \\
(\%)\end{array}$ & $\begin{array}{c}\text { Chrysophyta } \\
\text { relative } \\
\text { abundance } \\
(\%)\end{array}$ & $\begin{array}{l}\text { Cryptophyta } \\
\text { relative } \\
\text { abundance } \\
(\%)\end{array}$ & $\begin{array}{c}\text { Cyanophyta } \\
\text { relative } \\
\text { abundance } \\
(\%)\end{array}$ & $\begin{array}{c}\text { Euglenophyta } \\
\text { relative } \\
\text { abundance } \\
(\%)\end{array}$ & $\begin{array}{c}\text { Pyrrophyta } \\
\text { relative } \\
\text { abundance } \\
(\%)\end{array}$ \\
\hline \multicolumn{8}{|c|}{ Wakarusa R nr Lawrence, KS (06891500) } \\
\hline $09 / 02 / 11$ & 25 & 8.9 & 0.0 & 27 & 39 & 0.014 & 0.0 \\
\hline $09 / 08 / 11$ & 44 & 9.3 & 0.18 & 23 & 24 & 0.0073 & 0.0 \\
\hline $09 / 12 / 11$ & $\mathrm{~nm}$ & $\mathrm{~nm}$ & $\mathrm{~nm}$ & $\mathrm{~nm}$ & $\mathrm{~nm}$ & $\mathrm{~nm}$ & $\mathrm{~nm}$ \\
\hline 09/20/11 & $\mathrm{nm}$ & $\mathrm{nm}$ & $\mathrm{nm}$ & $\mathrm{nm}$ & $\mathrm{nm}$ & $\mathrm{nm}$ & $\mathrm{nm}$ \\
\hline $09 / 26 / 11$ & $\mathrm{~nm}$ & $\mathrm{~nm}$ & $\mathrm{~nm}$ & $\mathrm{~nm}$ & $\mathrm{~nm}$ & $\mathrm{~nm}$ & $\mathrm{~nm}$ \\
\hline $10 / 03 / 11$ & $\mathrm{~nm}$ & $\mathrm{~nm}$ & $\mathrm{~nm}$ & $\mathrm{~nm}$ & $\mathrm{~nm}$ & $\mathrm{~nm}$ & $\mathrm{~nm}$ \\
\hline $10 / 05 / 11$ & -- & -- & -- & -- & -- & -- & -- \\
\hline $10 / 11 / 11$ & -- & -- & -- & -- & -- & -- & -- \\
\hline $10 / 17 / 11$ & -- & -- & -- & -- & -- & -- & -- \\
\hline $10 / 24 / 11$ & -- & -- & -- & -- & -- & -- & -- \\
\hline $10 / 31 / 11$ & -- & -- & -- & -- & -- & -- & -- \\
\hline \multicolumn{8}{|c|}{ Kansas River main-stem sampling sites } \\
\hline \multicolumn{8}{|c|}{ Kansas R at Fort Riley, KS (06879100) } \\
\hline $09 / 02 / 11$ & 26 & 1.7 & 0.0 & 13 & 59 & 0.0 & 0.0 \\
\hline 09/08/11 & 71 & 4.0 & 0.0 & 10 & 14 & 0.0073 & 0.0 \\
\hline $09 / 12 / 11$ & $\mathrm{~nm}$ & $\mathrm{~nm}$ & $\mathrm{~nm}$ & $\mathrm{~nm}$ & $\mathrm{~nm}$ & $\mathrm{~nm}$ & $\mathrm{~nm}$ \\
\hline 09/20/11 & $\mathrm{nm}$ & $\mathrm{nm}$ & $\mathrm{nm}$ & $\mathrm{nm}$ & $\mathrm{nm}$ & $\mathrm{nm}$ & $\mathrm{nm}$ \\
\hline $09 / 26 / 11$ & $\mathrm{~nm}$ & $\mathrm{~nm}$ & $\mathrm{~nm}$ & $\mathrm{~nm}$ & $\mathrm{~nm}$ & $\mathrm{~nm}$ & $\mathrm{~nm}$ \\
\hline $10 / 03 / 11$ & $\mathrm{~nm}$ & $\mathrm{~nm}$ & $\mathrm{~nm}$ & $\mathrm{~nm}$ & $\mathrm{~nm}$ & $\mathrm{~nm}$ & $\mathrm{~nm}$ \\
\hline $10 / 05 / 11$ & -- & -- & -- & -- & -- & -- & -- \\
\hline $10 / 11 / 11$ & -- & -- & -- & -- & -- & -- & -- \\
\hline $10 / 17 / 11$ & -- & -- & -- & -- & -- & -- & -- \\
\hline $10 / 24 / 11$ & -- & -- & -- & -- & -- & -- & -- \\
\hline $10 / 31 / 11$ & -- & -- & -- & -- & -- & -- & -- \\
\hline \multicolumn{8}{|c|}{ Kansas R at Manhattan, KS (06879820) } \\
\hline $09 / 02 / 11$ & 51 & 3.0 & 0.0 & 12 & 34 & 0.0035 & 0.0 \\
\hline 09/08/11 & 74 & 6.8 & 0.0 & 7.8 & 11 & 0.0 & 0.0 \\
\hline $09 / 12 / 11$ & $\mathrm{~nm}$ & $\mathrm{~nm}$ & $\mathrm{~nm}$ & $\mathrm{~nm}$ & $\mathrm{~nm}$ & $\mathrm{~nm}$ & $\mathrm{~nm}$ \\
\hline $09 / 20 / 11$ & $\mathrm{~nm}$ & $\mathrm{~nm}$ & $\mathrm{~nm}$ & $\mathrm{~nm}$ & $\mathrm{~nm}$ & $\mathrm{~nm}$ & $\mathrm{~nm}$ \\
\hline $09 / 26 / 11$ & $\mathrm{~nm}$ & $\mathrm{~nm}$ & $\mathrm{~nm}$ & $\mathrm{~nm}$ & $\mathrm{~nm}$ & $\mathrm{~nm}$ & $\mathrm{~nm}$ \\
\hline $10 / 03 / 11$ & $\mathrm{~nm}$ & $\mathrm{~nm}$ & $\mathrm{~nm}$ & $\mathrm{~nm}$ & $\mathrm{~nm}$ & $\mathrm{~nm}$ & $\mathrm{~nm}$ \\
\hline $10 / 05 / 11$ & -- & -- & -- & -- & -- & -- & -- \\
\hline $10 / 11 / 11$ & -- & -- & -- & -- & -- & -- & -- \\
\hline $10 / 17 / 11$ & -- & -- & -- & -- & -- & -- & -- \\
\hline $10 / 24 / 11$ & -- & -- & -- & -- & -- & -- & -- \\
\hline $10 / 31 / 11$ & -- & -- & -- & -- & -- & -- & -- \\
\hline
\end{tabular}


Appendix 4. Phytoplankton community composition in samples collected from Kansas River tributary and main-stem sites during September and October 2011.-Continued

[cells/mL, cells per milliliter; \%, percent; nr, near; KS, Kansas; --, sample not collected; nm, analyte not measured but sample archived; R, River; Pl, Plaza]

\begin{tabular}{|c|c|c|c|c|c|c|c|c|}
\hline Date & $\begin{array}{l}\text { Phytoplankton } \\
\text { abundance } \\
\text { (cells/mL) }\end{array}$ & $\begin{array}{c}\text { Bacillariophyta } \\
\text { abundance } \\
\text { (cells/mL) }\end{array}$ & $\begin{array}{l}\text { Chlorophyta } \\
\text { abundance } \\
\text { (cells/mL) }\end{array}$ & $\begin{array}{l}\text { Chrysophyta } \\
\text { abundance } \\
\text { (cells/mL) }\end{array}$ & $\begin{array}{c}\text { Cryptophyta } \\
\text { abundance } \\
\text { (cells/mL) }\end{array}$ & $\begin{array}{c}\text { Cyanophyta } \\
\text { abundance } \\
\text { (cells/mL) }\end{array}$ & $\begin{array}{l}\text { Euglenophyta } \\
\text { abundance } \\
\text { (cells/mL) }\end{array}$ & $\begin{array}{c}\text { Pyrrophyta } \\
\text { abundance } \\
\text { (cells/mL) }\end{array}$ \\
\hline \multicolumn{9}{|c|}{ Kansas R at Wamego, KS (06887500) } \\
\hline $09 / 02 / 11$ & 22,000 & 13,000 & 1,600 & 0.0 & 4,200 & 3,400 & 0.0 & 0.0 \\
\hline 09/08/11 & 24,000 & 17,000 & 1,900 & 0.0 & 4,400 & 550 & 0.0 & 0.0 \\
\hline 09/12/11 & 37,000 & 35,000 & 290 & 0.0 & 1,700 & 0.0 & 0.0 & 0.0 \\
\hline 09/20/11 & 7,200 & 5,200 & 87 & 0.0 & 1,400 & 530 & 0.0 & 0.0 \\
\hline $09 / 26 / 11$ & 16,000 & 12,000 & 290 & 0.0 & 2,600 & 710 & 0.0 & 0.0 \\
\hline $10 / 03 / 11$ & 12,000 & 9,300 & 810 & 0.0 & 1,900 & 510 & 0.0 & 0.0 \\
\hline $10 / 05 / 11$ & 3,100 & 2,600 & 110 & 0.0 & 430 & 0.0 & 0.0 & 0.0 \\
\hline $10 / 11 / 11$ & $\mathrm{~nm}$ & $\mathrm{~nm}$ & $\mathrm{~nm}$ & $\mathrm{~nm}$ & $\mathrm{~nm}$ & $\mathrm{~nm}$ & $\mathrm{~nm}$ & $\mathrm{~nm}$ \\
\hline $10 / 17 / 11$ & $\mathrm{~nm}$ & $\mathrm{~nm}$ & $\mathrm{~nm}$ & $\mathrm{~nm}$ & $\mathrm{~nm}$ & $\mathrm{~nm}$ & $\mathrm{~nm}$ & $\mathrm{~nm}$ \\
\hline $10 / 24 / 11$ & $\mathrm{~nm}$ & $\mathrm{~nm}$ & $\mathrm{~nm}$ & $\mathrm{~nm}$ & $\mathrm{~nm}$ & $\mathrm{~nm}$ & $\mathrm{~nm}$ & $\mathrm{~nm}$ \\
\hline $10 / 31 / 11$ & $\mathrm{~nm}$ & $\mathrm{~nm}$ & $\mathrm{~nm}$ & $\mathrm{~nm}$ & $\mathrm{~nm}$ & $\mathrm{~nm}$ & $\mathrm{~nm}$ & $\mathrm{~nm}$ \\
\hline \multicolumn{9}{|c|}{ Kansas R nr Belvue, KS (06888350) } \\
\hline $09 / 02 / 11$ & 68,000 & 26,000 & 3,800 & 0.0 & 15,000 & 23,000 & 0.0 & 0.0 \\
\hline 09/08/11 & -- & -- & -- & -- & -- & -- & -- & -- \\
\hline $09 / 12 / 11$ & -- & -- & -- & -- & -- & -- & -- & -- \\
\hline 09/20/11 & -- & -- & -- & -- & -- & -- & -- & -- \\
\hline $09 / 26 / 11$ & -- & -- & -- & -- & -- & -- & -- & -- \\
\hline $10 / 03 / 11$ & -- & -- & -- & -- & -- & -- & -- & -- \\
\hline $10 / 05 / 11$ & -- & -- & -- & -- & -- & -- & -- & -- \\
\hline $10 / 11 / 11$ & -- & -- & -- & -- & -- & -- & -- & -- \\
\hline $10 / 17 / 11$ & -- & -- & -- & -- & -- & -- & -- & -- \\
\hline $10 / 24 / 11$ & -- & -- & -- & -- & -- & -- & -- & -- \\
\hline $10 / 31 / 11$ & -- & -- & -- & -- & -- & -- & -- & -- \\
\hline \multicolumn{9}{|c|}{ Kansas R at Topeka, KS (06889000) } \\
\hline $09 / 02 / 11$ & 47,000 & 35,000 & 2,200 & 0.0 & 6,500 & 3,400 & 0.0 & 0.0 \\
\hline 09/08/11 & 44,000 & 25,000 & 870 & 0.0 & 1,700 & 17,000 & 0.20 & 0.0 \\
\hline $09 / 12 / 11$ & $\mathrm{~nm}$ & $\mathrm{~nm}$ & $\mathrm{~nm}$ & $\mathrm{~nm}$ & $\mathrm{~nm}$ & $\mathrm{~nm}$ & $\mathrm{~nm}$ & $\mathrm{~nm}$ \\
\hline 09/20/11 & 23,000 & 20,000 & 230 & 0.0 & 2,100 & 200 & 0.0 & 0.0 \\
\hline $09 / 26 / 11$ & 27,000 & 24,000 & 720 & 0.0 & 2,800 & 0.0 & 0.0 & 0.0 \\
\hline $10 / 03 / 11$ & 29,000 & 24,000 & 920 & 0.0 & 2,200 & 1,100 & 0.0 & 0.0 \\
\hline $10 / 05 / 11$ & -- & -- & -- & -- & -- & -- & -- & -- \\
\hline $10 / 11 / 11$ & $\mathrm{~nm}$ & $\mathrm{~nm}$ & $\mathrm{~nm}$ & $\mathrm{~nm}$ & $\mathrm{~nm}$ & $\mathrm{~nm}$ & $\mathrm{~nm}$ & $\mathrm{~nm}$ \\
\hline $10 / 17 / 11$ & $\mathrm{~nm}$ & $\mathrm{~nm}$ & $\mathrm{~nm}$ & $\mathrm{~nm}$ & $\mathrm{~nm}$ & $\mathrm{~nm}$ & $\mathrm{~nm}$ & $\mathrm{~nm}$ \\
\hline $10 / 24 / 11$ & $\mathrm{~nm}$ & $\mathrm{~nm}$ & $\mathrm{~nm}$ & $\mathrm{~nm}$ & $\mathrm{~nm}$ & $\mathrm{~nm}$ & $\mathrm{~nm}$ & $\mathrm{~nm}$ \\
\hline $10 / 31 / 11$ & $\mathrm{~nm}$ & $\mathrm{~nm}$ & $\mathrm{~nm}$ & $\mathrm{~nm}$ & $\mathrm{~nm}$ & $\mathrm{~nm}$ & $\mathrm{~nm}$ & $\mathrm{~nm}$ \\
\hline
\end{tabular}


Appendix 4. Phytoplankton community composition in samples collected from Kansas River tributary and main-stem sites during September and October 2011.-Continued

[cells/mL, cells per milliliter; \%, percent; nr, near; KS, Kansas; --, sample not collected; nm, analyte not measured but sample archived; R, River; Pl, Plaza]

\begin{tabular}{|c|c|c|c|c|c|c|c|}
\hline Date & $\begin{array}{c}\text { Bacillariophyta } \\
\text { relative } \\
\text { abundance } \\
(\%)\end{array}$ & $\begin{array}{l}\text { Chlorophyta } \\
\text { relative } \\
\text { abundance } \\
(\%)\end{array}$ & $\begin{array}{l}\text { Chrysophyta } \\
\text { relative } \\
\text { abundance } \\
(\%)\end{array}$ & $\begin{array}{c}\text { Cryptophyta } \\
\text { relative } \\
\text { abundance } \\
(\%)\end{array}$ & $\begin{array}{l}\text { Cyanophyta } \\
\text { relative } \\
\text { abundance } \\
(\%)\end{array}$ & $\begin{array}{c}\text { Euglenophyta } \\
\text { relative } \\
\text { abundance } \\
(\%)\end{array}$ & $\begin{array}{c}\text { Pyrrophyta } \\
\text { relative } \\
\text { abundance } \\
(\%)\end{array}$ \\
\hline \multicolumn{8}{|c|}{ Kansas R at Wamego, KS (06887500) } \\
\hline $09 / 02 / 11$ & 58 & 7.3 & 0.0 & 19 & 15 & 0.0 & 0.0 \\
\hline 09/08/11 & 71 & 7.8 & 0.0 & 19 & 2.3 & 0.0 & 0.0 \\
\hline $09 / 12 / 11$ & 95 & 0.79 & 0.0 & 4.6 & 0 & 0.0 & 0.0 \\
\hline $09 / 20 / 11$ & 72 & 1.2 & 0.0 & 20 & 7.3 & 0.0 & 0.0 \\
\hline $09 / 26 / 11$ & 77 & 1.8 & 0.0 & 16 & 4.5 & 0.0 & 0.0 \\
\hline $10 / 03 / 11$ & 74 & 6.5 & 0.0 & 15 & 4.1 & 0.0 & 0.0 \\
\hline $10 / 05 / 11$ & 83 & 3.6 & 0.0 & 14 & 0.0 & 0.0 & 0.0 \\
\hline $10 / 11 / 11$ & $\mathrm{~nm}$ & $\mathrm{~nm}$ & $\mathrm{~nm}$ & $\mathrm{~nm}$ & $\mathrm{~nm}$ & $\mathrm{~nm}$ & $\mathrm{~nm}$ \\
\hline $10 / 17 / 11$ & $\mathrm{~nm}$ & $\mathrm{~nm}$ & $\mathrm{~nm}$ & $\mathrm{~nm}$ & $\mathrm{~nm}$ & $\mathrm{~nm}$ & $\mathrm{~nm}$ \\
\hline $10 / 24 / 11$ & $\mathrm{~nm}$ & $\mathrm{~nm}$ & $\mathrm{~nm}$ & $\mathrm{~nm}$ & $\mathrm{~nm}$ & $\mathrm{~nm}$ & $\mathrm{~nm}$ \\
\hline $10 / 31 / 11$ & $\mathrm{~nm}$ & $\mathrm{~nm}$ & $\mathrm{~nm}$ & $\mathrm{~nm}$ & $\mathrm{~nm}$ & $\mathrm{~nm}$ & $\mathrm{~nm}$ \\
\hline \multicolumn{8}{|c|}{ Kansas R nr Belvue, KS (06888350) } \\
\hline $09 / 02 / 11$ & 38 & 5.6 & 0.0 & 22 & 34 & 0.0 & 0.0 \\
\hline 09/08/11 & -- & -- & -- & -- & -- & -- & -- \\
\hline $09 / 12 / 11$ & -- & -- & -- & -- & -- & -- & -- \\
\hline 09/20/11 & -- & -- & -- & -- & -- & -- & -- \\
\hline $09 / 26 / 11$ & -- & -- & -- & -- & -- & -- & -- \\
\hline $10 / 03 / 11$ & -- & -- & -- & -- & -- & -- & -- \\
\hline $10 / 05 / 11$ & -- & -- & -- & -- & -- & -- & -- \\
\hline $10 / 11 / 11$ & -- & -- & -- & -- & -- & -- & -- \\
\hline $10 / 17 / 11$ & -- & -- & -- & -- & -- & -- & -- \\
\hline $10 / 24 / 11$ & -- & -- & -- & -- & -- & -- & -- \\
\hline $10 / 31 / 11$ & -- & -- & -- & -- & -- & -- & -- \\
\hline \multicolumn{8}{|c|}{ Kansas R at Topeka, KS (06889000) } \\
\hline $09 / 02 / 11$ & 74 & 4.6 & 0.0 & 14 & 7.2 & 0.0 & 0.0 \\
\hline 09/08/11 & 55 & 2.0 & 0.0 & 3.9 & 39 & 0.00045 & 0.0 \\
\hline $09 / 12 / 11$ & $\mathrm{~nm}$ & $\mathrm{~nm}$ & $\mathrm{~nm}$ & $\mathrm{~nm}$ & $\mathrm{~nm}$ & $\mathrm{~nm}$ & $\mathrm{~nm}$ \\
\hline 09/20/11 & 89 & 1.0 & 0.0 & 9.4 & 0.88 & 0.0 & 0.0 \\
\hline $09 / 26 / 11$ & 87 & 2.7 & 0.0 & 10 & 0.0 & 0.0 & 0.0 \\
\hline $10 / 03 / 11$ & 85 & 3.2 & 0.0 & 7.7 & 3.7 & 0.0 & 0.0 \\
\hline $10 / 05 / 11$ & -- & -- & -- & -- & -- & -- & -- \\
\hline $10 / 11 / 11$ & $\mathrm{~nm}$ & $\mathrm{~nm}$ & $\mathrm{~nm}$ & $\mathrm{~nm}$ & $\mathrm{~nm}$ & $\mathrm{~nm}$ & $\mathrm{~nm}$ \\
\hline $10 / 17 / 11$ & $\mathrm{~nm}$ & $\mathrm{~nm}$ & $\mathrm{~nm}$ & $\mathrm{~nm}$ & $\mathrm{~nm}$ & $\mathrm{~nm}$ & $\mathrm{~nm}$ \\
\hline $10 / 24 / 11$ & $\mathrm{~nm}$ & $\mathrm{~nm}$ & $\mathrm{~nm}$ & $\mathrm{~nm}$ & $\mathrm{~nm}$ & $\mathrm{~nm}$ & $\mathrm{~nm}$ \\
\hline $10 / 31 / 11$ & $\mathrm{~nm}$ & $\mathrm{~nm}$ & $\mathrm{~nm}$ & $\mathrm{~nm}$ & $\mathrm{~nm}$ & $\mathrm{~nm}$ & $\mathrm{~nm}$ \\
\hline
\end{tabular}


Appendix 4. Phytoplankton community composition in samples collected from Kansas River tributary and main-stem sites during September and October 2011.-Continued

[cells/mL, cells per milliliter; \%, percent; nr, near; KS, Kansas; --, sample not collected; nm, analyte not measured but sample archived; R, River; Pl, Plaza]

\begin{tabular}{|c|c|c|c|c|c|c|c|c|}
\hline Date & $\begin{array}{c}\text { Phytoplankton } \\
\text { abundance } \\
\text { (cells/mL) }\end{array}$ & $\begin{array}{c}\text { Bacillariophyta } \\
\text { abundance } \\
\text { (cells/mL) }\end{array}$ & $\begin{array}{l}\text { Chlorophyta } \\
\text { abundance } \\
\text { (cells/mL) }\end{array}$ & $\begin{array}{l}\text { Chrysophyta } \\
\text { abundance } \\
\text { (cells/mL) }\end{array}$ & $\begin{array}{c}\text { Cryptophyta } \\
\text { abundance } \\
\text { (cells/mL) }\end{array}$ & $\begin{array}{c}\text { Cyanophyta } \\
\text { abundance } \\
\text { (cells/mL) }\end{array}$ & $\begin{array}{l}\text { Euglenophyta } \\
\text { abundance } \\
\text { (cells/mL) }\end{array}$ & $\begin{array}{c}\text { Pyrrophyta } \\
\text { abundance } \\
\text { (cells/mL) }\end{array}$ \\
\hline \multicolumn{9}{|c|}{ Kansas R at Lecompton, KS (06891000) } \\
\hline $09 / 02 / 11$ & 100,000 & 85,000 & 6,000 & 0.0 & 9,700 & 950 & 0.67 & 0.0 \\
\hline 09/08/11 & 41,000 & 21,000 & 2,500 & 0.0 & 6,700 & 10,000 & 0.0 & 0.67 \\
\hline 09/12/11 & 29,000 & 21,000 & 750 & 0.0 & 2,100 & 5,700 & 0.0 & 0.0 \\
\hline 09/20/11 & 15,000 & 14,000 & 73 & 0.0 & 180 & 390 & 0.0 & 0.0 \\
\hline $09 / 26 / 11$ & 35,000 & 31,000 & 1,500 & 0.0 & 2,300 & 0.0 & 0.0 & 0.0 \\
\hline $10 / 03 / 11$ & 50,000 & 45,000 & 420 & 0.0 & 2,700 & 1,000 & 0.0 & 0.0 \\
\hline $10 / 05 / 11$ & 45,000 & 37,000 & 2,000 & 0.0 & 4,500 & 940 & 0.0 & 0.0 \\
\hline $10 / 11 / 11$ & -- & -- & -- & -- & -- & -- & -- & -- \\
\hline $10 / 17 / 11$ & -- & -- & -- & -- & -- & -- & -- & -- \\
\hline $10 / 24 / 11$ & -- & -- & -- & -- & -- & -- & -- & -- \\
\hline $10 / 31 / 11$ & -- & -- & -- & -- & -- & -- & -- & -- \\
\hline \multicolumn{9}{|c|}{ Kansas R at Lawrence, KS (06891080) } \\
\hline $09 / 02 / 11$ & -- & -- & -- & -- & -- & -- & -- & -- \\
\hline 09/08/11 & -- & -- & -- & -- & -- & -- & -- & -- \\
\hline 09/12/11 & -- & -- & -- & -- & -- & -- & -- & -- \\
\hline 09/20/11 & 13,000 & 12,000 & 0.0 & 0.0 & 530 & 0.0 & 0.0 & 0.0 \\
\hline 09/26/11 & 20,000 & 19,000 & 10 & 0.0 & 1,300 & 0.0 & 0.0 & 0.0 \\
\hline $10 / 03 / 11$ & 34,000 & 31,000 & 460 & 0.0 & 840 & 2,100 & 0.0 & 0.0 \\
\hline $10 / 05 / 11$ & -- & -- & -- & -- & -- & -- & -- & -- \\
\hline $10 / 11 / 11$ & -- & -- & -- & -- & -- & -- & -- & -- \\
\hline $10 / 17 / 11$ & -- & -- & -- & -- & -- & -- & -- & -- \\
\hline $10 / 24 / 11$ & -- & -- & -- & -- & -- & -- & -- & -- \\
\hline $10 / 31 / 11$ & -- & -- & -- & -- & -- & -- & -- & -- \\
\hline \multicolumn{9}{|c|}{ Kansas R at Desoto, KS (06892350) } \\
\hline $09 / 02 / 11$ & 140,000 & 110,000 & 13,000 & 0.0 & 15,000 & 2,400 & 0.0 & 0.0 \\
\hline 09/08/11 & 190,000 & 160,000 & 7,100 & 0.0 & 23,000 & 2,300 & 428 & 0.0 \\
\hline 09/12/11 & 42,000 & 36,000 & 1,300 & 0.0 & 4,400 & 0.0 & 0.0 & 0.0 \\
\hline 09/20/11 & 22,000 & 20,000 & 210 & 0.0 & 1,800 & 0.0 & 0.0 & 0.0 \\
\hline 09/26/11 & 15,000 & 14,000 & 340 & 0.0 & 890 & 0.0 & 0.0 & 0.0 \\
\hline $10 / 03 / 11$ & 54,000 & 46,000 & 4,500 & 0.0 & 2,800 & 13 & 0.0 & 0.0 \\
\hline $10 / 05 / 11$ & -- & -- & -- & -- & -- & -- & -- & -- \\
\hline $10 / 11 / 11$ & 170,000 & 150,000 & 6,300 & 0.0 & 13,000 & 0.0 & 0.0 & 0.0 \\
\hline $10 / 17 / 11$ & 190,000 & 150,000 & 19,000 & 0.0 & 16,000 & 0.0 & 0.0 & 0.0 \\
\hline $10 / 24 / 11$ & 140,000 & 117,000 & 13,000 & 0.0 & 9,400 & 0.0 & 0.0 & 0.0 \\
\hline $10 / 31 / 11$ & 80,000 & 69,000 & 5,400 & 0.0 & 5,300 & 670 & 0.0 & 0.0 \\
\hline
\end{tabular}


Appendix 4. Phytoplankton community composition in samples collected from Kansas River tributary and main-stem sites during September and October 2011.-Continued

[cells/mL, cells per milliliter; \%, percent; nr, near; KS, Kansas; --, sample not collected; nm, analyte not measured but sample archived; R, River; Pl, Plaza]

\begin{tabular}{|c|c|c|c|c|c|c|c|}
\hline Date & $\begin{array}{c}\text { Bacillariophyta } \\
\text { relative } \\
\text { abundance } \\
(\%)\end{array}$ & $\begin{array}{c}\text { Chlorophyta } \\
\text { relative } \\
\text { abundance } \\
(\%)\end{array}$ & $\begin{array}{l}\text { Chrysophyta } \\
\text { relative } \\
\text { abundance } \\
(\%)\end{array}$ & $\begin{array}{l}\text { Cryptophyta } \\
\text { relative } \\
\text { abundance } \\
(\%)\end{array}$ & $\begin{array}{l}\text { Cyanophyta } \\
\text { relative } \\
\text { abundance } \\
(\%)\end{array}$ & $\begin{array}{c}\text { Euglenophyta } \\
\text { relative } \\
\text { abundance } \\
(\%)\end{array}$ & $\begin{array}{c}\text { Pyrrophyta } \\
\text { relative } \\
\text { abundance } \\
(\%)\end{array}$ \\
\hline \multicolumn{8}{|c|}{ Kansas R at Lecompton, KS (06891000) } \\
\hline $09 / 02 / 11$ & 84 & 5.9 & 0.0 & 9.5 & 0.93 & 0.00065 & 0.0 \\
\hline 09/08/11 & 83 & 6.1 & 0.0 & 16 & 25 & 0.0 & 0.0016 \\
\hline $09 / 12 / 11$ & 71 & 2.6 & 0.0 & 7.1 & 19 & 0.0 & 0.0 \\
\hline $09 / 20 / 11$ & 96 & 0.48 & 0.0 & 1.2 & 2.6 & 0.0 & 0.0 \\
\hline $09 / 26 / 11$ & 89 & 4.2 & 0.0 & 6.5 & 0.0 & 0.0 & 0.0 \\
\hline $10 / 03 / 11$ & 92 & 0.85 & 0.0 & 5.5 & 2.1 & 0.0 & 0.0 \\
\hline $10 / 05 / 11$ & 83 & 4.9 & 0.0 & 10 & 2.1 & 0.0 & 0.0 \\
\hline $10 / 11 / 11$ & -- & -- & -- & -- & -- & -- & -- \\
\hline $10 / 17 / 11$ & -- & -- & -- & -- & -- & -- & -- \\
\hline $10 / 24 / 11$ & -- & -- & -- & -- & -- & -- & -- \\
\hline $10 / 31 / 11$ & -- & -- & -- & -- & -- & -- & -- \\
\hline \multicolumn{8}{|c|}{ Kansas R at Lawrence, KS (06891080) } \\
\hline $09 / 02 / 11$ & -- & -- & -- & -- & -- & -- & -- \\
\hline 09/08/11 & -- & -- & -- & -- & -- & -- & -- \\
\hline $09 / 12 / 11$ & -- & -- & -- & -- & -- & -- & -- \\
\hline 09/20/11 & 96 & 0.0 & 0.0 & 4.2 & 0.0 & 0.0 & 0.0 \\
\hline $09 / 26 / 11$ & 93 & 0.05 & 0.0 & 6.6 & 0.0 & 0.0 & 0.0 \\
\hline $10 / 03 / 11$ & 90 & 1.4 & 0.0 & 2.5 & 6.0 & 0.0 & 0.0 \\
\hline $10 / 05 / 11$ & -- & -- & -- & -- & -- & -- & -- \\
\hline $10 / 11 / 11$ & -- & -- & -- & -- & -- & -- & -- \\
\hline $10 / 17 / 11$ & -- & -- & -- & -- & -- & -- & -- \\
\hline $10 / 24 / 11$ & -- & -- & -- & -- & -- & -- & -- \\
\hline $10 / 31 / 11$ & -- & -- & -- & -- & -- & -- & -- \\
\hline \multicolumn{8}{|c|}{ Kansas R at Desoto, KS (06892350) } \\
\hline $09 / 02 / 11$ & 78 & 9.0 & 0.0 & 11 & 1.7 & 0.0 & 0.0 \\
\hline 09/08/11 & 83 & 3.6 & 0.0 & 12 & 1.2 & 0.22 & 0.0 \\
\hline 09/12/11 & 86 & 3.1 & 0.0 & 11 & 0.0 & 0.0 & 0.0 \\
\hline 09/20/11 & 91 & 0.97 & 0.0 & 8.0 & 0.0 & 0.0 & 0.0 \\
\hline $09 / 26 / 11$ & 92 & 2.3 & 0.0 & 6.0 & 0.0 & 0.0 & 0.0 \\
\hline $10 / 03 / 11$ & 86 & 8.3 & 0.0 & 5.3 & 0.02 & 0.0 & 0.0 \\
\hline $10 / 05 / 11$ & -- & -- & -- & -- & -- & -- & -- \\
\hline $10 / 11 / 11$ & 88 & 3.8 & 0.0 & 8.1 & 0.0 & 0.0 & 0.0 \\
\hline $10 / 17 / 11$ & 21 & 10 & 0.0 & 8.5 & 0.0 & 0.0 & 0.0 \\
\hline $10 / 24 / 11$ & 84 & 9.6 & 0.0 & 6.7 & 0.0 & 0.0 & 0.0 \\
\hline $10 / 31 / 11$ & 86 & 6.7 & 0.0 & 6.6 & 0.84 & 0.0 & 0.0 \\
\hline
\end{tabular}


Appendix 4. Phytoplankton community composition in samples collected from Kansas River tributary and main-stem sites during September and October 2011.-Continued

[cells/mL, cells per milliliter; \%, percent; nr, near; KS, Kansas; --, sample not collected; nm, analyte not measured but sample archived; R, River; Pl, Plaza]

\begin{tabular}{|c|c|c|c|c|c|c|c|c|}
\hline Date & $\begin{array}{l}\text { Phytoplankton } \\
\text { abundance } \\
\text { (cells/mL) }\end{array}$ & $\begin{array}{l}\text { Bacillariophyta } \\
\text { abundance } \\
\text { (cells/mL) }\end{array}$ & $\begin{array}{l}\text { Chlorophyta } \\
\text { abundance } \\
\text { (cells/mL) }\end{array}$ & $\begin{array}{l}\text { Chrysophyta } \\
\text { abundance } \\
\text { (cells/mL) }\end{array}$ & $\begin{array}{l}\text { Cryptophyta } \\
\text { abundance } \\
\text { (cells/mL) }\end{array}$ & $\begin{array}{c}\text { Cyanophyta } \\
\text { abundance } \\
\text { (cells/mL) }\end{array}$ & $\begin{array}{c}\text { Euglenophyta } \\
\text { abundance } \\
\text { (cells/mL) }\end{array}$ & $\begin{array}{c}\text { Pyrrophyta } \\
\text { abundance } \\
\text { (cells/mL) }\end{array}$ \\
\hline \multicolumn{9}{|c|}{ Kansas R nr I-435 Bridge, KS (06892518) } \\
\hline $09 / 02 / 11$ & 320,000 & 260,000 & 27,000 & 0.0 & 17,000 & 13,000 & 2.0 & 0.0 \\
\hline 09/08/11 & 120,000 & 93,000 & 8,500 & 0.0 & 8,300 & 6,600 & 36 & 0.0 \\
\hline $09 / 12 / 11$ & $\mathrm{~nm}$ & $\mathrm{~nm}$ & $\mathrm{~nm}$ & $\mathrm{~nm}$ & $\mathrm{~nm}$ & $\mathrm{~nm}$ & $\mathrm{~nm}$ & $\mathrm{~nm}$ \\
\hline 09/20/11 & $\mathrm{nm}$ & $\mathrm{nm}$ & $\mathrm{nm}$ & $\mathrm{nm}$ & $\mathrm{nm}$ & $\mathrm{nm}$ & $\mathrm{nm}$ & $\mathrm{nm}$ \\
\hline $09 / 26 / 11$ & $\mathrm{~nm}$ & $\mathrm{~nm}$ & $\mathrm{~nm}$ & $\mathrm{~nm}$ & $\mathrm{~nm}$ & $\mathrm{~nm}$ & $\mathrm{~nm}$ & $\mathrm{~nm}$ \\
\hline $10 / 03 / 11$ & $\mathrm{~nm}$ & $\mathrm{~nm}$ & $\mathrm{~nm}$ & $\mathrm{~nm}$ & $\mathrm{~nm}$ & $\mathrm{~nm}$ & $\mathrm{~nm}$ & $\mathrm{~nm}$ \\
\hline $10 / 05 / 11$ & -- & -- & -- & -- & -- & -- & -- & -- \\
\hline $10 / 11 / 11$ & -- & -- & -- & -- & -- & -- & -- & -- \\
\hline $10 / 17 / 11$ & -- & -- & -- & -- & -- & -- & -- & -- \\
\hline $10 / 24 / 11$ & -- & -- & -- & -- & -- & -- & -- & -- \\
\hline $10 / 31 / 11$ & -- & -- & -- & -- & -- & -- & -- & -- \\
\hline
\end{tabular}


Appendix 4. Phytoplankton community composition in samples collected from Kansas River tributary and main-stem sites during September and October 2011.-Continued

[cells/mL, cells per milliliter; \%, percent; nr, near; KS, Kansas; --, sample not collected; nm, analyte not measured but sample archived; R, River; Pl, Plaza]

\begin{tabular}{cccccccc}
\hline Date & $\begin{array}{c}\text { Bacillariophyta } \\
\text { relative } \\
\text { abundance } \\
(\%)\end{array}$ & $\begin{array}{c}\text { Chlorophyta } \\
\text { relative } \\
\text { abundance } \\
(\%)\end{array}$ & $\begin{array}{c}\text { Chrysophyta } \\
\text { relative } \\
\text { abundance } \\
(\%)\end{array}$ & $\begin{array}{c}\text { Cryptophyta } \\
\text { relative } \\
\text { abundance } \\
(\%)\end{array}$ & $\begin{array}{c}\text { Cyanophyta } \\
\text { relative } \\
\text { abundance } \\
(\%)\end{array}$ & $\begin{array}{c}\text { Euglenophyta } \\
\text { relative } \\
\text { abundance } \\
(\%)\end{array}$ & $\begin{array}{c}\text { Pyrrophyta } \\
\text { relative } \\
\text { abundance } \\
(\%)\end{array}$ \\
\hline & & & Kansas R nr l-435 & Bridge, KS (06892518) & & & \\
\hline $09 / 02 / 11$ & 82 & 8.3 & 0.0 & 5.4 & 4.2 & 0.00063 & 0.0 \\
$09 / 08 / 11$ & 80 & 7.3 & 0.0 & 7.1 & 5.7 & 0.031 & 0.0 \\
$09 / 12 / 11$ & $\mathrm{~nm}$ & $\mathrm{~nm}$ & $\mathrm{~nm}$ & $\mathrm{~nm}$ & $\mathrm{~nm}$ & $\mathrm{~nm}$ & $\mathrm{~nm}$ \\
$09 / 20 / 11$ & $\mathrm{~nm}$ & $\mathrm{~nm}$ & $\mathrm{~nm}$ & $\mathrm{~nm}$ & $\mathrm{~nm}$ & $\mathrm{~nm}$ & $\mathrm{~nm}$ \\
$09 / 26 / 11$ & $\mathrm{~nm}$ & $\mathrm{~nm}$ & $\mathrm{~nm}$ & $\mathrm{~nm}$ & $\mathrm{~nm}$ & $\mathrm{~nm}$ & $\mathrm{~nm}$ \\
$10 / 03 / 11$ & $\mathrm{~nm}$ & $\mathrm{~nm}$ & $\mathrm{~nm}$ & $\mathrm{~nm}$ & $\mathrm{~nm}$ & $\mathrm{~nm}$ & $\mathrm{~nm}$ \\
$10 / 05 / 11$ & -- & -- & -- & -- & -- & -- & -- \\
$10 / 11 / 11$ & -- & -- & -- & -- & -- & -- & - \\
$10 / 17 / 11$ & -- & -- & -- & -- & -- & - & - \\
$10 / 24 / 11$ & -- & -- & -- & -- & -- & - & - \\
$10 / 31 / 11$ & -- & -- & -- & -- & - & - \\
\hline
\end{tabular}


Publishing support provided by: Rolla Publishing Service Center

For additional information concerning this publication, contact: Director, USGS Kansas Water Science Center

4821 Quail Crest Place

Lawrence, KS 66049

(785) 842-9909

Or visit the Kansas Water Science Center Web Site at: http://ks.water.usgs.gov 

